Portland State University

PDXScholar

1971

\title{
An exploration into the applicability of a psychological technique for anthropological research
}

Gwendolyn Marie Harris Pierce

Portland State University

Follow this and additional works at: https://pdxscholar.library.pdx.edu/open_access_etds

Part of the Gender, Race, Sexuality, and Ethnicity in Communication Commons, Interpersonal and Small Group Communication Commons, and the Social and Cultural Anthropology Commons Let us know how access to this document benefits you.

\section{Recommended Citation}

Pierce, Gwendolyn Marie Harris, "An exploration into the applicability of a psychological technique for anthropological research" (1971). Dissertations and Theses. Paper 1456.

https://doi.org/10.15760/etd.1455

This Thesis is brought to you for free and open access. It has been accepted for inclusion in Dissertations and Theses by an authorized administrator of PDXScholar. Please contact us if we can make this document more accessible: pdxscholar@pdx.edu. 
AN ABSTRACT OP THE THESTS OF Gwendolyn Marle Harris Plerce for the Master of Arte in Anthropology presented December 15. 1971.

Titles An Exploration Into the Applicability of a Psyohologioal Teohnique for Anthropologloal Besearoh.

APPBOVED BY YEMBERS OF THE THESIS COUITYER:

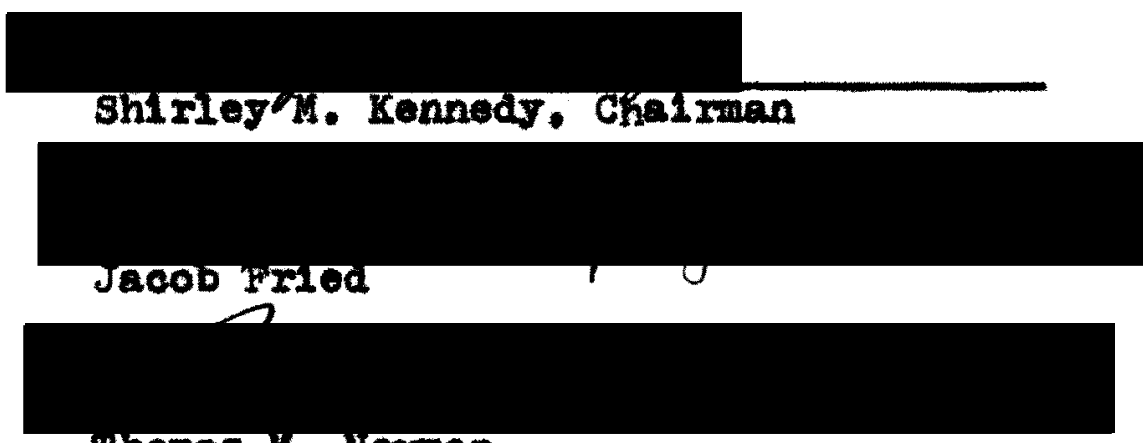

Thomes K. Neman

Th1s thesis purporte to explore and describe the types of information that would be obtainable to the anthropological researoher if he used the minlmally atruotured amall group (MDMS-SG) teohnlque with members of selected ethnio sroup. The approson was tried an Jepanese Portland State UnIrersity etudents and also on Saudi Arab Portland state Unlversity students for $81 x$ -essions each. They werr told that a graduate anthropology atudent wanted to get to know then and learn what they thought she should know about their countries. 
The sessions were taped and notes written after esoh session. This corpus of material was analyzed using the olosed corpus teohnlque whloh necessitates use of the ent1re corpus and only the corpus. Post-categorization was used, 1t belng especially appropriate in pilot studies and/or in original exploratory researoh where the emphais is on induotion rather than doduotion.

The verbal and other bohavioral phenomena exhibited by the two "oultural" groups was compared and an attempt made to 1solate that whloh as datinotively Arab or Japanese. Presence-absence counts and the relative frequenoy with whioh beharioxal items were exhiblted determined whother or not an item was differentlating.

Those differonoes oocurred in alx major areas which Inoluded responses to the constants of the total situation. pattorms of organization, paralingulatio phonomena exhibited, Interaction patterna diaplayed, emotions expressed and flaily the subject matter disoussed. These then are areas for or aspets about which the anthropological investigator oan expect to obtain data if ho uses the MDMS-SG wth "oultural" groups.

These differonoes were then compared wth information gathered about Arab and Japanese oultures from other souroes.

The woricing hypothesis that the Arab sroup would sontancousiy oxhibit ignifloant behavioral differences 
from the Japanese sroup under MDMS-8G conditions and that these alfrexenoes would be rolated to the ethnio backGround of that larger population of which they are a part was ut1112ed.

The two groups were abstantially different and these alfferences were in the direotion of the difrerenoes between the two ethnio groups from whioh they come. Therefore the assumption, while not proved, was substantially strengthened.

In the Arab and Japanese groups, it was found that the group reactions to the total altuation--the physical surroundings, the investigator, the raot of moeting at al1. etc.--alnost all oolnolded with the witten 11ternture. It would seen therefore that the Mous-SG could be used prlor to fleld work with an unstudied group.

organlzational patterms are 1doally and eas1ly studied through the use of the MDMS-SG. It could be a part of orery ethnology besldes having praotioal signifloance (1.0. In faoliltating international oomunioation) but is only raroly etudied now.

Parallinguiatio phenomena can be easily observed in the MDMS-3G. Work in this f101d is usually $11 \mathrm{mited}$ to observation of alngle Individual rather than of one Individual at a time in a sroup setting. This thesis represents an Innovation in this respect.

Interaotion patterns and emotional expression in 
groups have not been traditionally studied by anthropologlsta. They are at least in part oulturaliy conditioned and oould legitimately beoows a part of every now standard othnography. The HDAS-SG provides a convenlent beglnning for anjone interested.

The content material, 1.0. the subjeots dis owsed wero for the most part oloarly ldentiflabio as eithor Japanese or Axab. The UDHS-SG ceeningly roflected the oultural conditianing of the groups oonoerned. However. material athered inoomplete.

An anthropologiat could not hope to IImit himself to the KDMS-SG aole2y. It 18 a supplementary teohnlque to be used by anthropologiots interested in obtaining the type of date it can provide. 


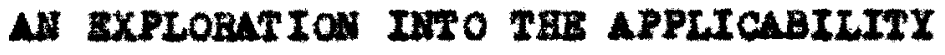

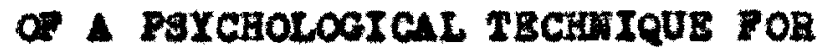 AMHROPOLOGTCAL BESEARCE
}

\author{
by \\ CUENDOTX MATE HARTS PTBRCE
}

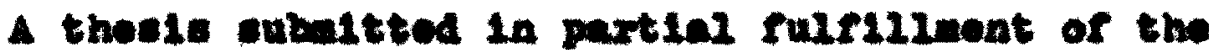
segulimente for the degree of
\end{abstract}

\author{
Heren of ares \\ in \\ ANXHEOPOLOCX
}

\section{Portland state Uatraze1ty \\ $19 \%$}




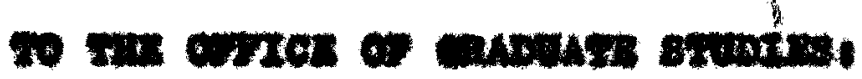

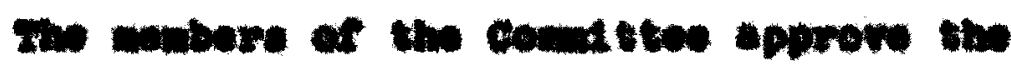

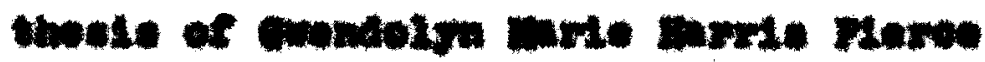
proveruted bowiver 15. 197.

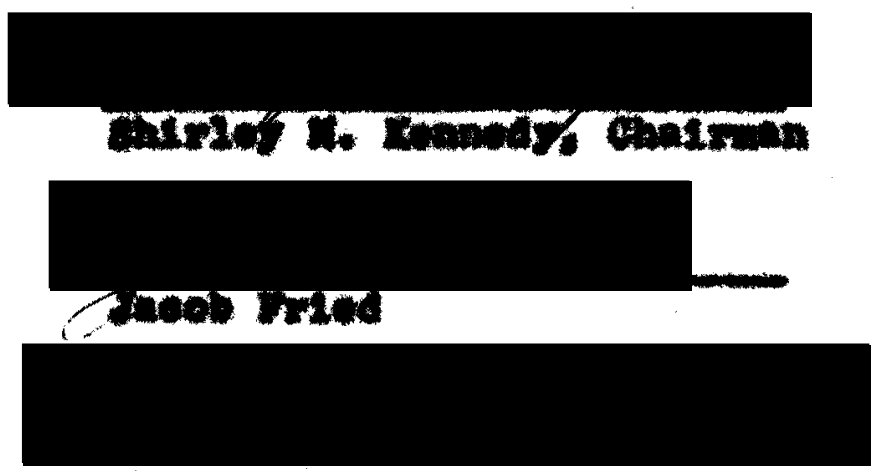

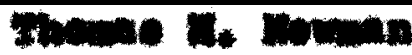

\section{Armatmat}

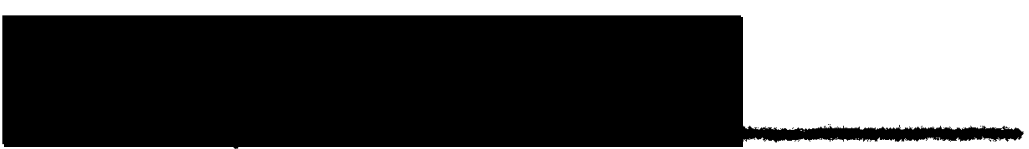

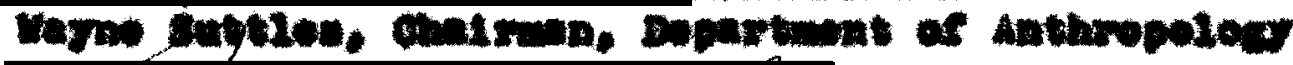

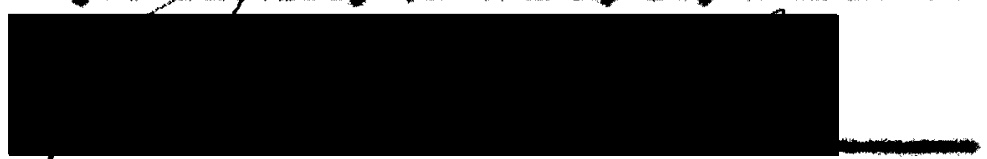

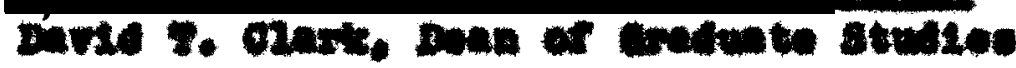


This work 18 dodieated to

v wothor and rathor.

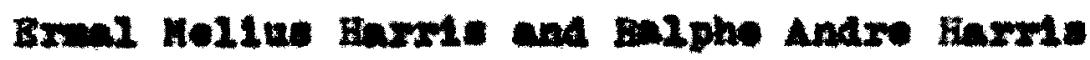




\section{ACrMOuLEDEHERs}

I wh to aoknowledge ay gratitude to the $\Delta \mathrm{rmb}$ and Japanoee otudents at Portiand state Univerelty who pertielpated in the projeet and without whoe oooperntien 14 would have been inposelble.

I fich to thank nombers of the andio-riental servioes

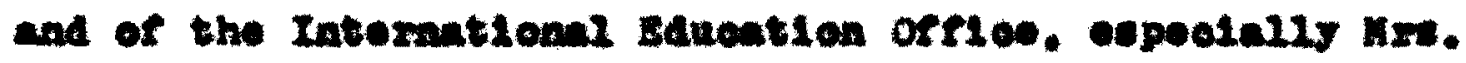
Hareuerite Nario and Mr. John Crlque for tholr enstetanee. I an also apprealative of the efforts of ay oondttes.

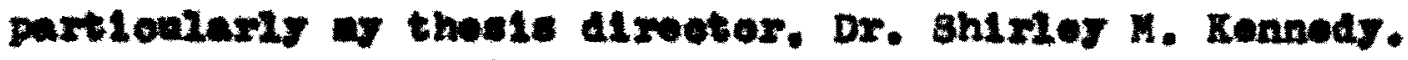

In the worde of a Japanose proverb.

"Mulm no arane. Took no kiku." 
TABLE OF corthars

PAGS

Acrronledondms ................... 121

LISR on raghes .................... $2 x$

urst of proungs .................... x

CHAFTER

I Imrroducrion ............... 1

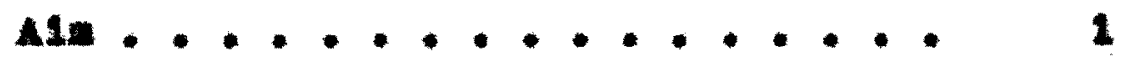

A Brler surver of Ethnoloston

Dnte Colleotlng Kothode.......

Detaxtiption of Payohologleal

Teohnique Eaplored .........

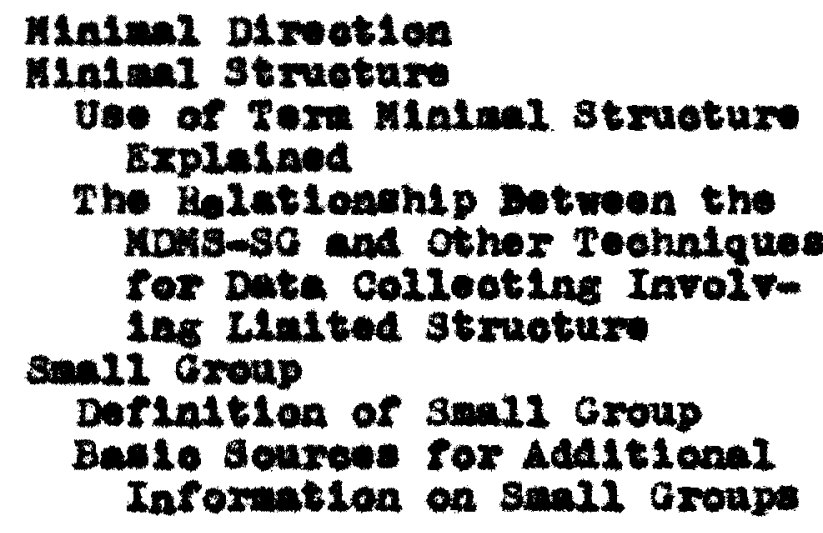

Hiotery of the Anthropologleal

ginil Group ............. 11

Broed statement of Problen ..... 15

sumang . . . . . . . . . . . 18

II MEKODOLOCY ................ 20

The sample seleotlea ........ 20 
The Throleal sottings The Loodtion. Proguenas and Hour of Hooting. . . . 25

Roordins the Matertal ......... 27

Smal1 Group charetertetsas and 2 hols nintlounh to the Role andox

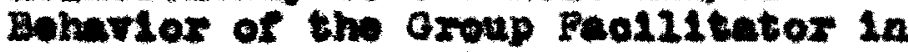

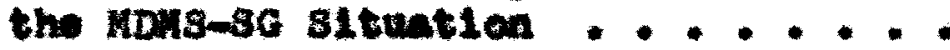

The Nethotelos Enplored in the

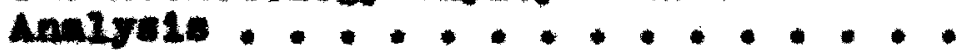

Spret 10 Souroe Book on Japanese and

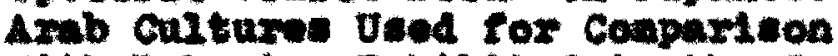

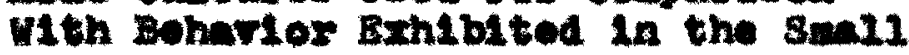
Grouph

sunaryx .................. 39

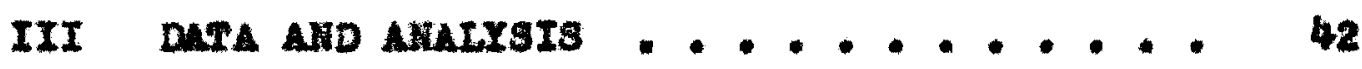

Tha sibution oriented obearvetione. 43

The Difrexential Respones of the Twe Gxoup to spelitio sepets of the Total s1tuntion zotal S1tuntion Moteing Arwengenents Tape Roconder Koxs Anpet or Neating

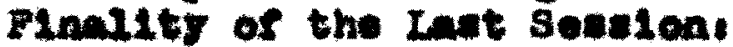
Beaponse to Texinction At ltude Tonme Group Fual14tator stenanaos Speolfle Aepeote of the rotel struntion to inlah the two oxwupe Responded sinlinity Suanst

Conbruting Patteras of orgunization Formed bo the 2 mo Croupe in Respoese to the MDMS-BO s1tuntion .......

The Pattem of organization in the Jaynene omoup Tho Pattern of Orgentzation in the Axul Group 


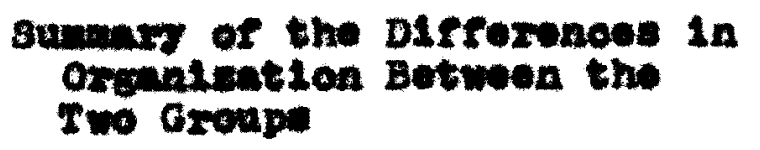

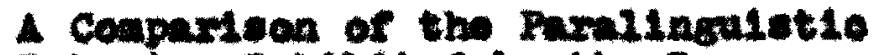
Banarior Bxhbled by the $\mathrm{xwo}$ Granis

\section{Sumanxy}

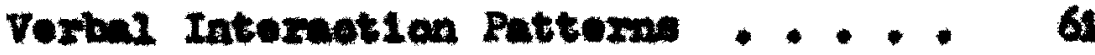

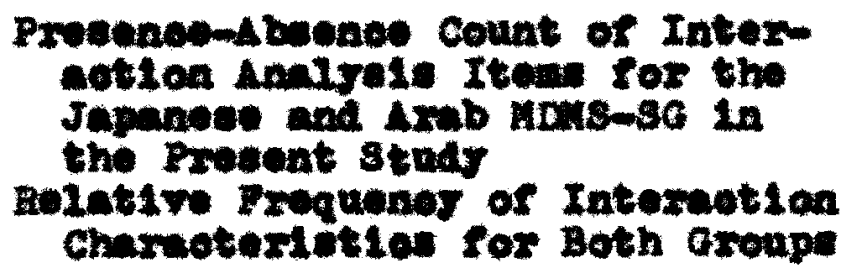

Bnothaw Inrezwod exan Vorbal Boharlor 1 is the contert of the Total Bohmriezel stenteloa ...................

Buotion Exhibited by Both Axabu and Jupunese in the KDHs-90

Enothan Ermiblted oaly in the Japinede Miramso

Enotion Brhsted ont in the A mab nors

Sumesy

Content Aantrote. . .............

Teptes Dreouned by Eoth Groups Donortptian of Itent Listed:

Itein 8 and 2 (ootwins Aeamented)

ponertption of Iten Litced:

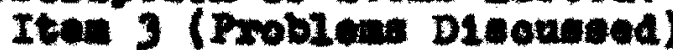

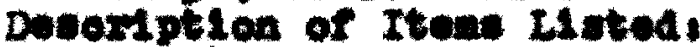

Itons 4 throash 10

(Iaromitea)

poples Dlecuened only br the

Arilo Grousy 
$\mathbf{n t}$

CMAPRER

PAGS

Toptes Diceuned bo tho Japande Group

sumary

sumary ................

99

IV THE RALTIONBHTP BETWEEN TEE DATA CBSEEVED

AMD PREVIONSLY PUBLISHED ATREOPOLOGICAL

nurentuls ...............

situatien Oxtentod Besponves .... 104

ioving Arrungenent:

Tape Beoondor

Tho Hinkeri -Di reotion Minimalstruoture Aepeot

gaspones to Terrination

the Attivie Dieplayed roman the Baslistutor

Atterdense

Rospense to Audio-VIsun

Teohnielian

Reaponate te Phraloal Condition of the Boen

suanery

Ceatruoting Patterne of Orcanization

Formed of the Two cxeap ....... 114

The Pattex of Oreanization in the Japanese Groapa

Diecuentien of the petterna of orginatention in the Afwb Group

Sumany, Oxganleatlonal Patterne

Pasallagatetio Baharior ...... 124

Verbal Intersetion Pattoras ..... 123

Enotion Interwed from Verbal Behavior Within the Coatext of the rotal

Behartoral situation........ 124

Content ................ 127 
$\nabla 11$

CHAPIER

PAOE

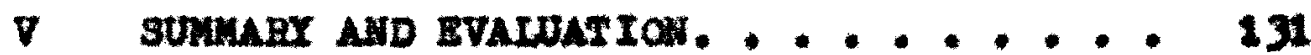

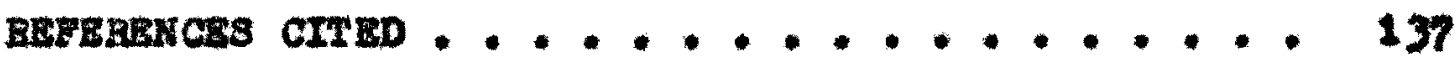




\section{LITS OF TABLBS}

TABI8 PAOE

I Nultivarte plotribution Chart Daploting the stininutiter and Difremanoe in the Churebersinter of tho Axb and the Jarmante and2 Grange........23 
ITse of Frouris

pravazs

PLGE

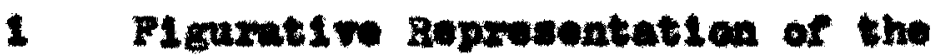

Japunoue orgutrationd Puttem in

the Proest HDms-so stuat ........ 52

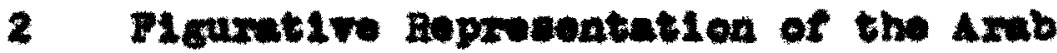

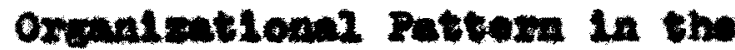

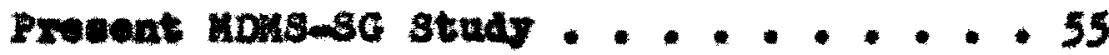

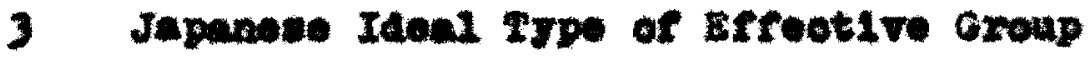

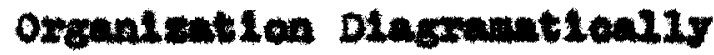

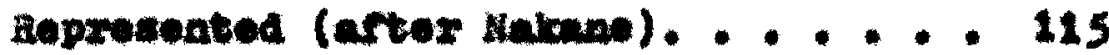

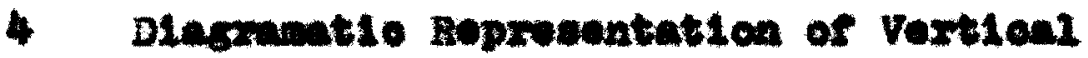

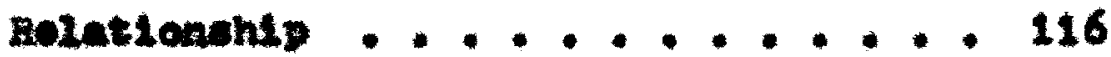

5 The Vortend Primelpal plactungtouly

Repsoneatod .................. 116 


\section{aturan 1}

Im moverexar

\section{Ax}

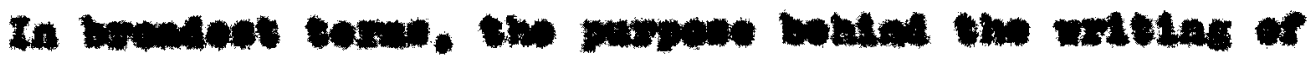

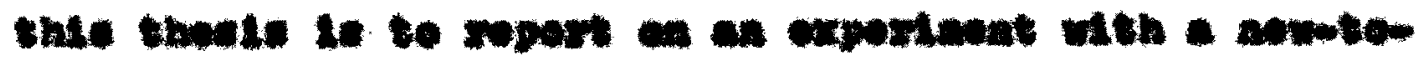

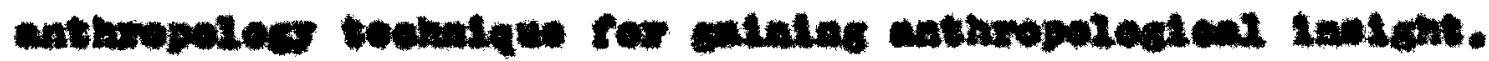

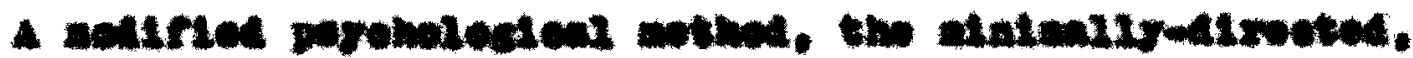

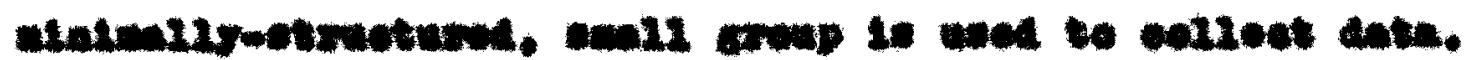

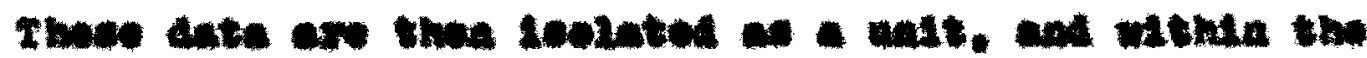

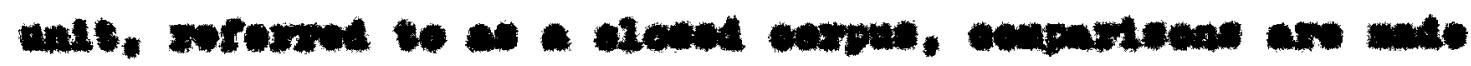

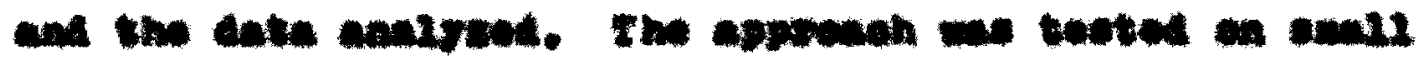

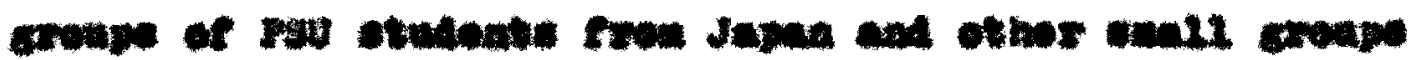

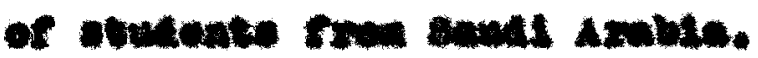

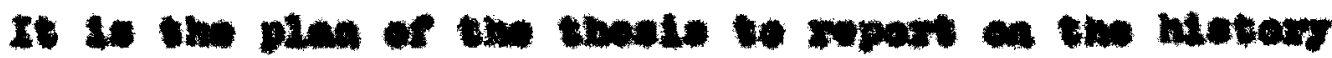

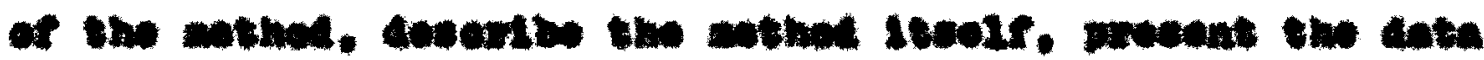

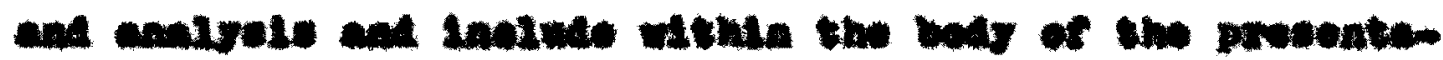

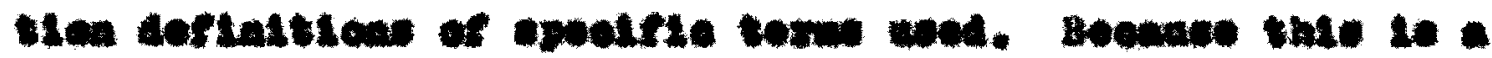

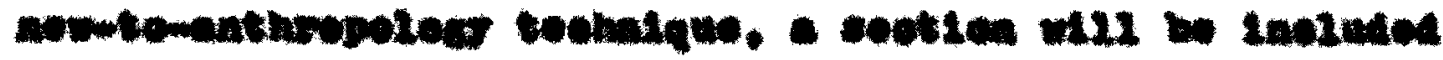

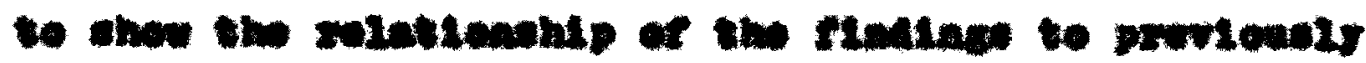

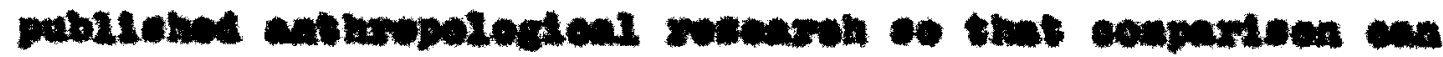

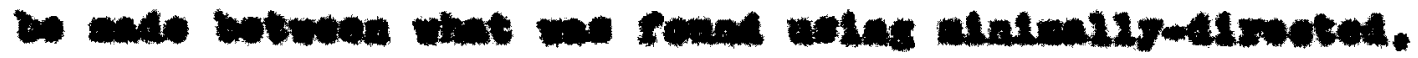

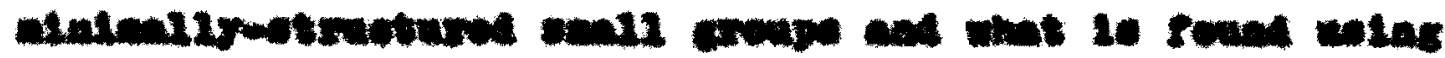


mox tradtional anthropologteal teohniques.

More epesifloally thie paper dovertbes the boharlor. prinalpalis the vertal bohavior, both oontent and atruoture, of two sumples of otudeate frem two alfrenent othale group. Amb and Japanese, In oxdex to wee what Afferences botween the two manplea anke thonselves apparent when the inveatigator ut1115es stringont toohnlqued (dorezoped in altaleal parohologr) to sininize his infiuonce on the exrop. 1.0. to prowent medelf from alreoting. controlling or 11mitlas pownible reapenses.

This atudy canoorns an Investigation of tho po-

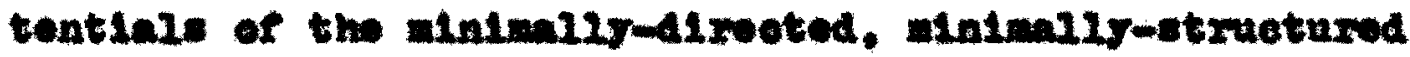

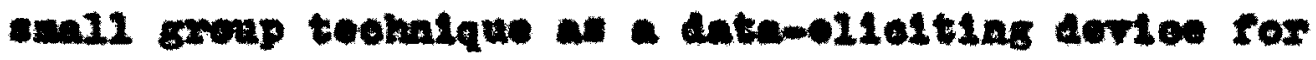
anthropolegteal researeh. Thie study lavelves the applioation of the teohnlque to undexwtind the boharioral phonemona exhibited by twe exltural sxoupa.

The prosent atud provies a camenutrmetion of a tool. It Is teohniealis not an exporinont ar a Inbozatory test,

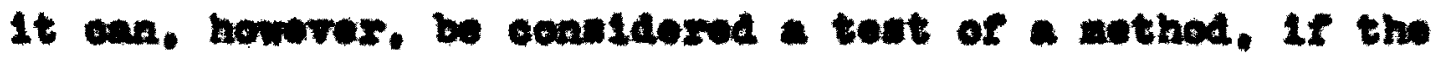
tew tert is dortinod breacis.

That boharion when is diatinetive and that which is aldive in the two gromp wil be igelated weins a cothod froquenty ut111sed in anthropologteal IIncuiation, the

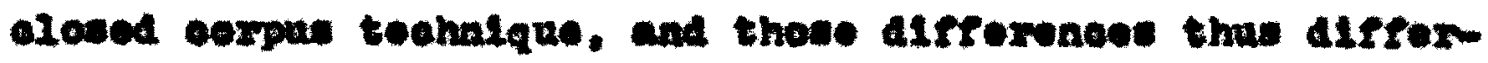
ontinted. Wll then be rolated when poosible to rindings of anthropolociste studing the oultures of the othnie groupe 
Invelved by differeat mane. In oxder to compars the types of ente ellosted.

In the following aubeotiea of the introduotoxy ohapter, a art hiotery of ethnolocical ante colleation nothed w11 be prosonted followed by a deseription of the upelfie poyahologten teohnlque enplored in tho present atudy. A alsongelon of tho ballo oonospte nininal-

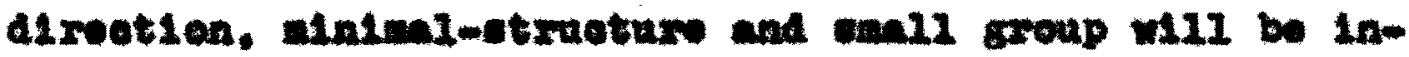
eluded. Bogause of the clese melationohlp botween the conoepto mininal otruotuxe and projeotive tochniques a

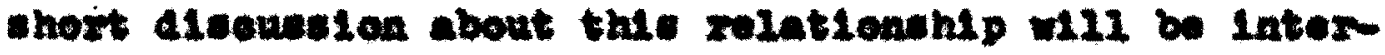
sporwed botwen seotions of this ohapter deroted to the

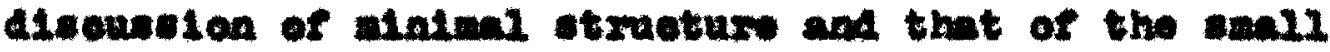
croup. The chapter w11 olose with a broad otatenont of the problen.

II. A BAIEF SUEVEY OF ERHNOLOGICAL DATA COLIECTING WETHODS

Varlowe wothod have been eaplored for obtainlng Afferent tjpes of etes in alfferont trpes of eltuation In the fleld of anthropologs. Moxe opeolfteally. In the

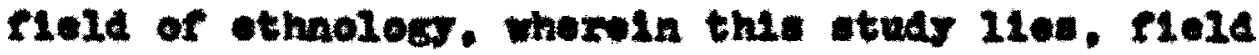
techalques Inviriablo Inelude the Indivldual Informal interviex, Alroet obeexmation and/or partiel pant ob eorvation, the latter lnoorporating the former. Orten, In adition, Inventorles, questionnalres, centue taking, 
weorde andrale and the historles of informante are weod. The rlezd of "payahologionl enthropologs." to whloh this atudy in solated, has, alnoe Ita inoeption, ut111zed many athode to obtali and interpsot data. Those inelude, In additien to the onos 1iated above, the ase of projeotive teohalques, enpeolaliy the horseheoh, and the TAT (w1th and

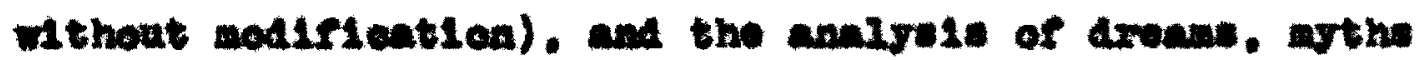
and art objooth. Inportant rewoaroh in the field Inoludes that of Hallowell (1942, 1945, 1949), Devoe (1960), Cuud11 (1949). Henry (1947), spinalex (1958) and woxe reoently. valinee (1970). Kaplan (1961). Hunt (1967) and Hex (1961) eaph edited oolloetsen of otwdies in the pormonality and

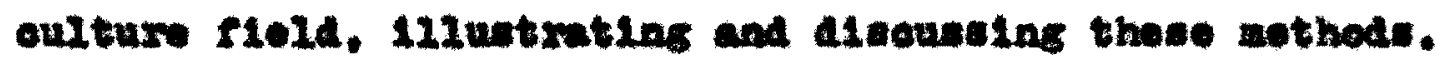

In the past those engend in poyohologion anthropoloex have for the wout part need pejohologlonl toohniquen and parohologteal thoerted to oxplatn anthropologleal phenosene. The pusent atudy follow the tradtion in that the technique uned for the collection of the reoord is

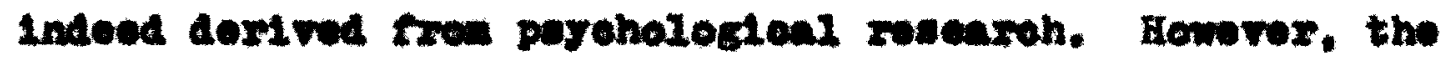
mothod of andrule is not bued on parohologloal theory but devaloped to woot tho anthropologionl goals. Malinowaki in he olmento dinousulen of wothods, stated at the final geal of the athnologlat ito arep the native polnt of riew, his

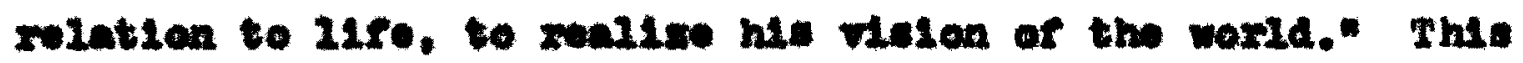
1. an woll the conoxal goul of the old Innguage and oulturo atudios (Baple 192., Whort 1956) whioh wexo Iater toxned 
ethnolinguiat1os (Hymes 1962), then othnoselenoe (stuxterant 1964, spradies 1969, Ooodenough 1956) and now oognltive anthropoloco (TJler 1969, Rowng and D'Andrade 1964). One of the objeative is to diseorer and desertbe both what is poreelrod as algnifieant for the poople of come oulture and how 1t 10 organlzod. Af pyler (1969:11)

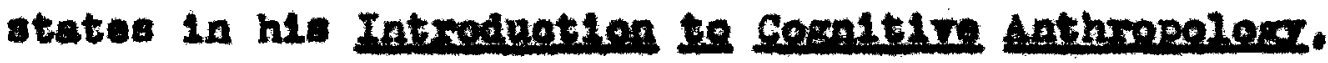

- . the anthropologiot mat avold loposing his own semant10 ontegerios on what he peroelves. wat attenpt to diseorex the cenantio world in which these people 117e. Thore are, then, two mas of bringling order out of apparent ohmos-inpege a proexinting onder on 1t. or dinegrer the order underlying it. Neariy all of eariler ant hropology was ohareoterized by the tiret mothod.

Cognitive anthropology and the present atudy are oharaoterlsed by the latter goal, that of arolding the imposition of external astegories on the data and of searohing for the order underlying 1t. The prosent study difrers from the eognitive atudies in that the sposfle mothodologion teohnlques of cognitive anthropolosg are not used.

III. DESCEIPTION OF PSYCHOLOGICAL TECHNIQUE BUPLOYBD

The apectio payohologienl teohnique used in this study is the minimally-direoted, minimally-struotured small group (haro-1n-arter reforred to al MDHB-SG). There are no pablieations that on orlent the reader to the anthropologien use of the MDAS-SG as this is an 
exploxatory vanture. Howerex, for backeround on the philosophy bohlad alatal drwotion, the miting of W11Lan Snyder (1947) and Carl Rogere (1948) on the non-

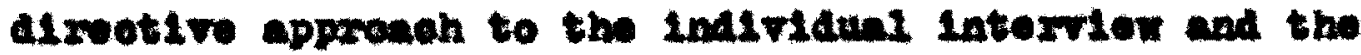
allent-oonterwe approsen oan bonulted. Gorolow. Hooh and Felechow (1952) wrote on the natuxe of nondimet17e group purahothexaps. They eoho Frake. Goodenough. Beplr and tho modern othnosolentlots in tholr appeal to sot at the otrueture and aleselfieation oratene of the people or pooplos belng atudied rathor than superInposins the ontegories of the lavetigator onte the data otud10d. For olarifleation the labelo ininimilydimoted, Alnimally-otruotured and anell group' w112 be aleovesed bolon in that oxter.

\section{Antina Daretion}

The torm Indendif-direoted has been oubetituted for

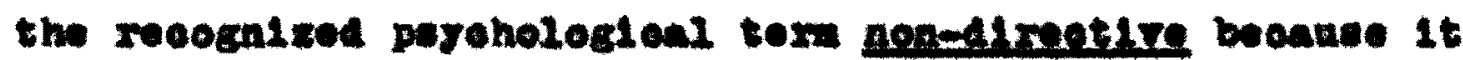
moxe sceurately desoribes what happens. Minimal-dirwotlea wee selooted prienrily so that the partiolpante belas obeorred had the greatent poestble freedon of oholee of

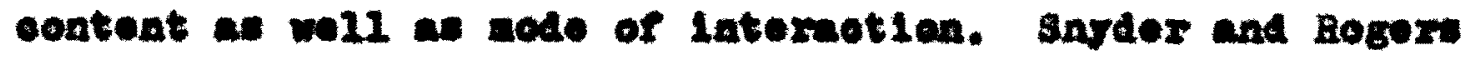
are olinioal payohologiate intervated in thoxepy. Ther and tholr followers tralnod others to be non-diswetive. It

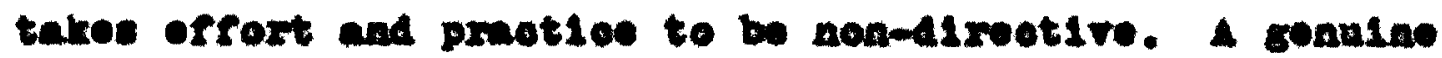

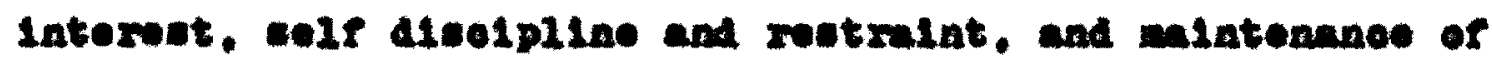


- non-judenontal att1tude and a ot toward objootivity and neutral1ty. all contribute to success in belag non11seot1re.

Hon-aireotiveness is ued here to desoribe the behariox of the Inveatigator whother ho works with one Individual at a tine or weveral almultangously. Although

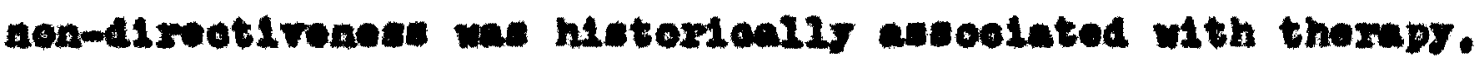
the conneotion lo not a noesenary one and in this case is unrolated.

\section{Mnina struatnx.}

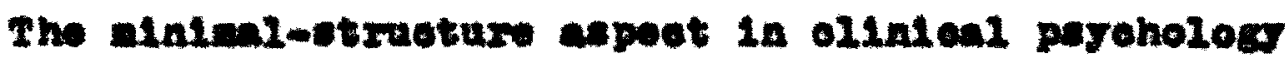
15 troated by Gaxdinor Lindxey (1961) In mo book

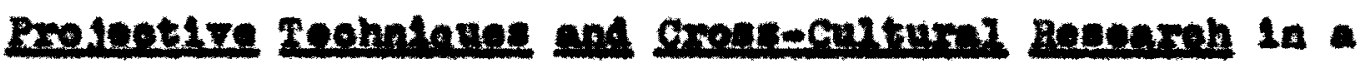
obapter disouestas thoorotion foundations.

Uee of the Ter Mntral stroture sxplatned. The term etzuoture is used here in a paychologioal sense, 1,e. - pleturs of a hunas belag ox a troe or ohnlx 10 noxo etruotured than a pleture of an lak blot. The 1megular odges, texture, eolor. ohape, ote. of tho Ink-blot are opan to - Iarger vamety of Interprotations and mosalag than is the plotux of a noxe ldentiflable objeat (1.e. In thle oulture. a plature of a otralght-baked ohalr.) It would be expooted that a bulnose wooting with an agond wovid bo mighy otruotured wherval if a fow of the monbers of tho same group who had attended the weoting later had corfoe 
together acd talked about whaterer thoy folt $11 \mathrm{ke}$ talking about, thor as a anal group would oxhiblt woh 2eas etruature. The nore 11elted the atruotare, the nore the

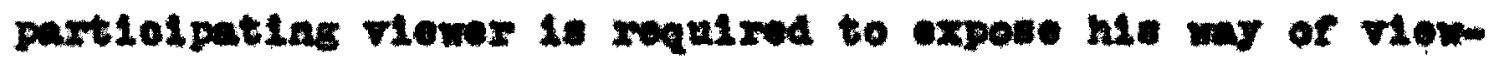
Ing all well as what ho soen. This inverwe relationship is baslo to thie researeh. Brexy projective technlque wed by paraholegiate ut1lises the prinolple of the 11mltation or atruature.

minimaily-otruotured" 10 also an attribute whioh is to a sxent extent under the alreet control of the investigater. It is a parpoely manpuzated abiguity. It Involves walting for leadorship to axtee whon it would be oaller for all oonoexned if the inveatigntor aluply took over. He wust raeliltate oomunleation ret rost the othor pertiolpants with the rosponsibility fox alrootion. It Involves moro than alting la the bekground and 11atening. It weane riaking borecten andor a riee of anxlety in others as well as in himself. It somotinos involvos not anking quostion or augsoting toplos for diaouselon in order to wee what toptos arise when the partielpante axe not pronpted.

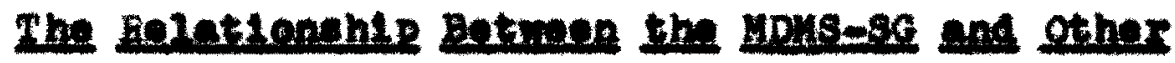

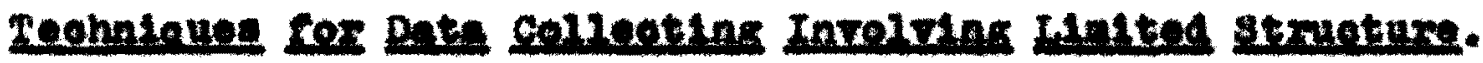
The Ilterntuse of pejohologion anthropolog abounde with the application of variou progeotive teohniqued, all enploring linitations of atruetur. 1.0. Rorsohnoh. 
Draw-amen test. T.A.T.. ocuplete-a-seatence, te., so 11elting etrueture per se 1s not now (Lindzey 1961). This Inventigation, howorer. is difroxent fros nost Investigations Inrolving the ooneppte "lindtation of atrueture" and "projeotive techalque" in that the mous-so In and of Iteolf is troated as a projottive dovioe. The projective derion 10 the stution 1 teele rather than, for example. a set or stianil on pleoes or papor. e.g. Bormehuoh, T.4.T. oto.

The Hows-86 is also related to the open-ended queatlon teohnique. Tho Moks-8G and proporly bo conoldered wo an extened on and modifiention of the provionely aentioned ecmplete-m-contenoe teohnlque (Coldbors 1965) and the opon-onded question teohnique both of whioh invelve the 11nitation of struotux., and ax in a brond senes prom jeotive in nature.

Sherif and cartwe $(1947,47)$ formulated the follow ing werieling hrpotheele.
- all othor thinge belng equal, the role played by Internal and soetal faotors deoreases with the atebility. olarity or etructurudnens of the stimu- Iue ol tuation and with the etrongth of franed or points of reforwase almendy ostablished.

This and its ooaverae it now generally coeopted. Pejohologtote, howerer, uewaily asawe that it is

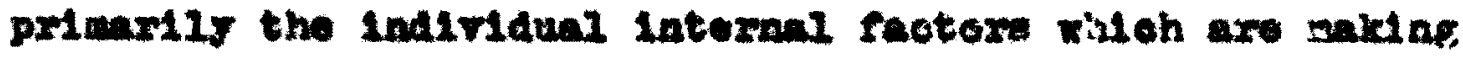
thanelves orident in minimaily otruotured altuation. 
The role played by soolal and eultural faotora 18 generally mininized as apoolfion loaraed by individunis. Paychologiate aro wualiy interosted in the indiridual, the norm, or the propose.

The anthropologlet, on the other hand, as a partielpant observer. If prinarily interented in the oodal or oultural faotoxs. He may unoonsolously we the mantphIation of degree of etructure and bonef1t fros the use but

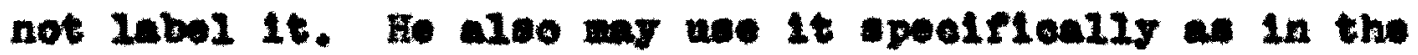
proseat inventigution as a tool to diesover oulturally relorat ata.

The uee of the MDMs-SG or an othar projective devioe eannot of couree separate thene facters for the inveat1gator. It is one of the objects of th1 atudy to ugseat a rosearoh dosign whioh would separate the Individual or Internal payohologioal motox from the woolal or oultural oner.

\section{Sneu arous}

Wh10 projeot17e tochniquee are wevally, but not almos, adniniatered and responded to Individunily. In this studr the respones to the stuntion are the rosponses of several people gathered almultanoously.

Definition of gavi Group. The tera mall group is used hore in 1te broad sonse to desoribe a gathoring of from three to apprexleately twenty people, Ineludins the 
partiolpant obeorver, whoh rosulte in sowothlng happening. The nueber of eotinge, tho number of people and what

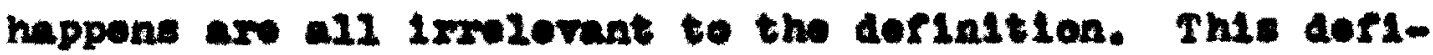
altion Io sindiar to that given by Bales (1950,33).

4 obell group is dotined as any number of persens ongaged in Intermotion with eaoh other in single

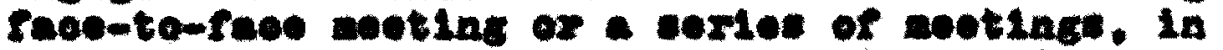
whioh eaoh nenber moelves enough inproeston or pereoption of enoh other nomber dietingt enough so that he oan. elthor at the tino or in Iater

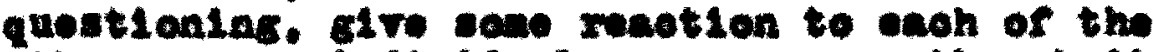
othere an an Indiridual pexeon. orea though it be caly to zoenll that the othor persen wa prosent.

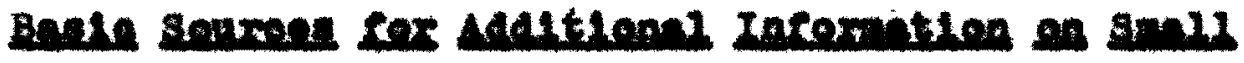
Gxomn. For additional Informetien on researeh on the small group, one alght aleo conmult, Hogrnth and Altann's

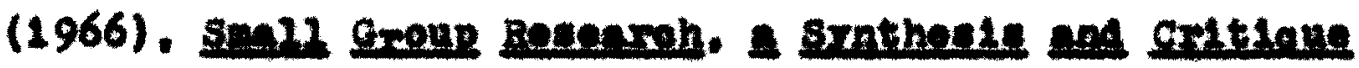

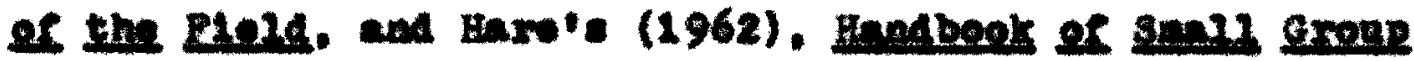
pecerreh. The foxes 11ets 2,108 soparate oxemplos of omall group reneareh and gives the purpose. procodure, rosults and atudy rarlebles if those ars rolevant, to sach or the studios. The Intter 11ate 1.385 group stadien under "gerermaees." Moorath and Altwan ars parohologlete. Haro 10 a eolologiat.

IV. HISTORY OF THE AMHROPOLOCTCAL SMALL GROUP

Not moh formal wall eroup researeh ha boon does in

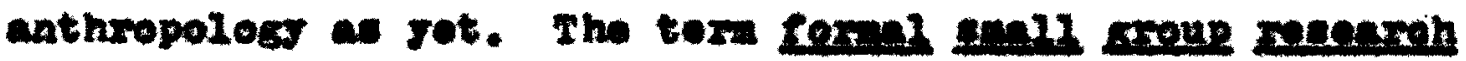
10 ued to differmatiate it from the prosese of elaply 
cacually talking to corenal people at the wane time in the coneral course of data gathoring in the atandard ethnoGrophie estuation.

Ervall (19630), Satmab (1970) and spradiey (1969) have all formod croupe for anthropolosteal purposes. Tholr celeotion of moabars. tho1r phrposes, tholr proesdures and

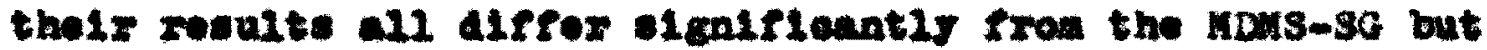
they are allke in that veleotion of Individunl reprosentatives of a Iarger othnis croup or onlture are. rolled upon to provide Infoxmation of Intereat to ethnogmaphexe.

Hobert B. Ekvall (1963) in the fall of 1960 under the aupleas of a Rookefoller Foundation grant brought a group of I Ibatan to the Univeralty of Vachington for a three rear poriod. Exvall uned the onall group approneh in his researoh. He conducted a conlare in which the partiol pante. no sad four Tibotane, Introdueod, dsoussed and olaselesed vaxious axpots of T2baten woolety and oulture. Dr. Ekvall (1963b!368) atatee.

Group liseweston, in mioh thanes and problend axe powed and dobuted bo thole who have been ande to ven that they aro gquale in collaborution (and who that boomo vituily intexonted in the rosulte of the proeens and the areenes of the projeot) 10 an extreanif effective fox of ellaltation. In suoh Alsouenlon, no ono's oplni on is saoxosanot, bat

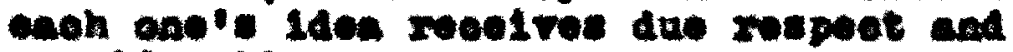
considention.

Elrva1, as a moult of his work with this greup was able to wite a book on TIbotan rollglous thanos and 
problom (1963a). a subjeot of parracunt lnterset to the partiolpants. HIs was the rirat published anthropologioal researoh whioh the investigator found in the 11 terature published ascoolated wth the formal nee of andil group mothodology. Besearohore fron ramioni diselplines besmo Interested and jolnod the conimar froe tine to tine. Jamon F. Downs. an anthropologist who joined the group in the vanner of 1963. publiabod on the role of antmale and on water ut1lization and rale in ribot, as a roalt of ha conteot wth Ekmal's croup (1962, 1963). Togothor they also otridted trade. anteal harbadry teghntques, nowsdisa and kinship.

Unlike the HDMs-go Ekrall's eroup wal oomposed of his former fleld Informate known to be rellable, knowledgeable and prestiglous. It wa atractured apparontiy in that

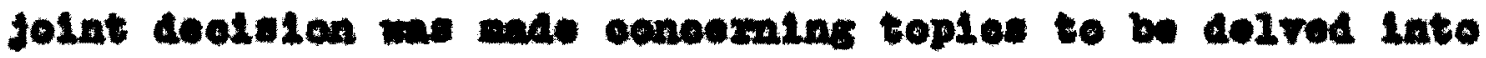

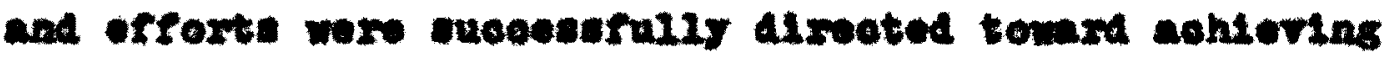
this objeotive cooporatively. It w121 be noted that this objeet2w an well as the athod alffor from that of this atraty.

In 2970, w1111en B. Sohmab ued onall group pro-

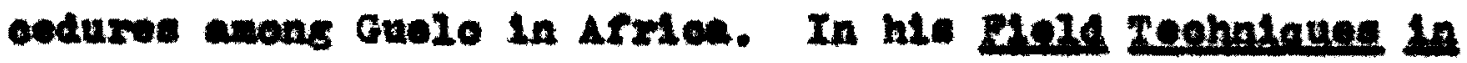

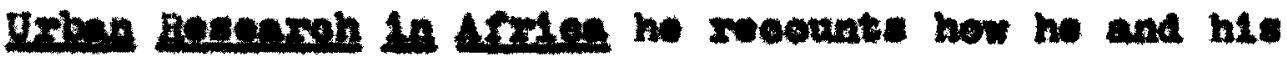
researoh teal, after thay ha taken a oonewe and InterFlownd a randen sanple, establishod a panel group sade up of twenty Afrieas who wore edueated, Ioh, inportant. 


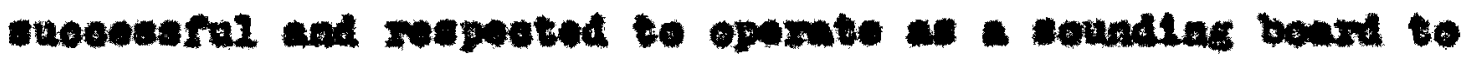

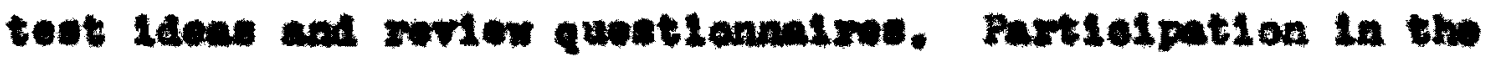

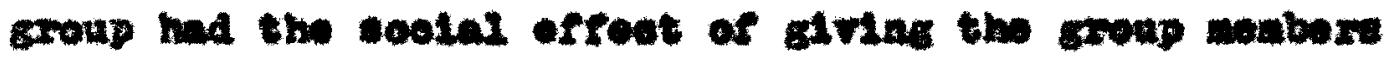

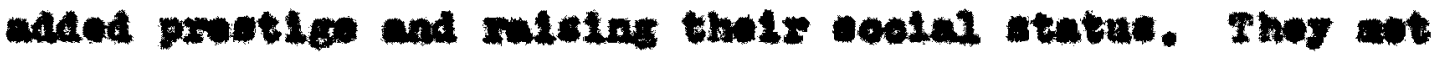

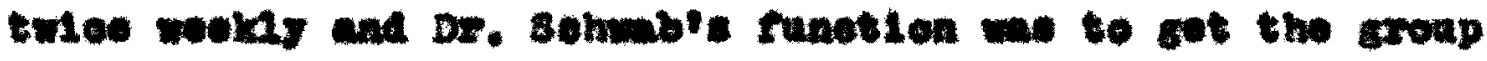

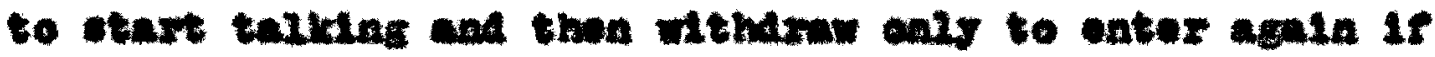

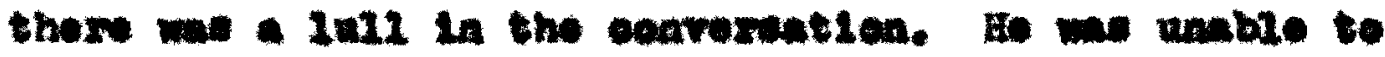

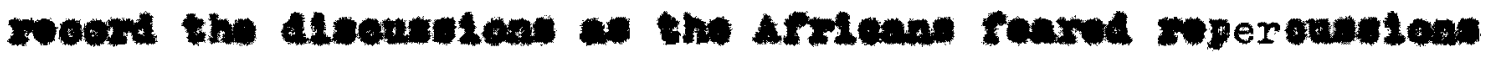
If the woeven foll inte the wrons bads.

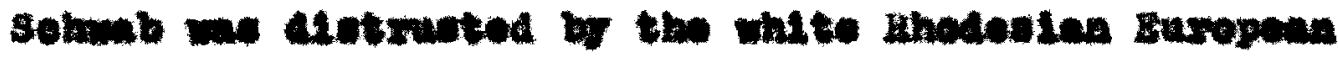

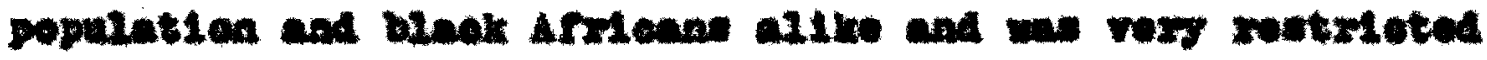

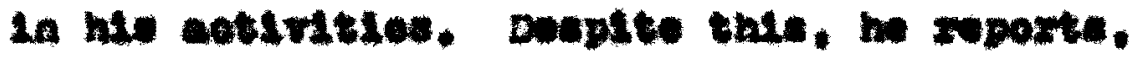

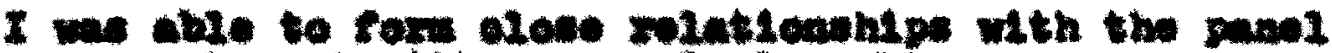

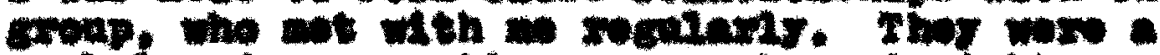

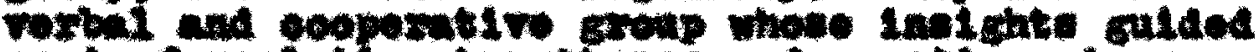

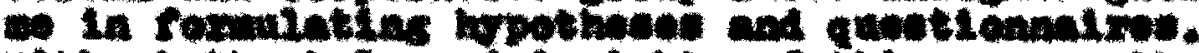
Whout the halp and inst thte of the croup. the

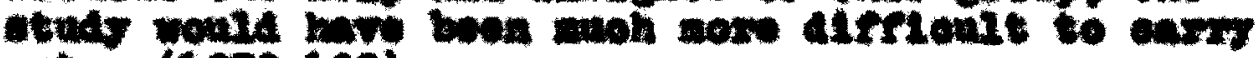
out. (19701100).

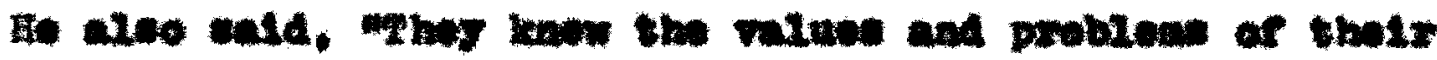

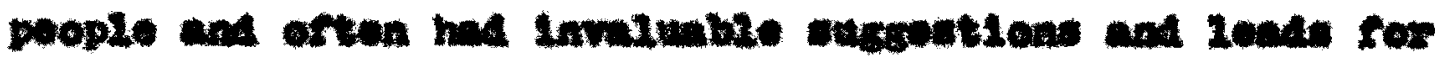

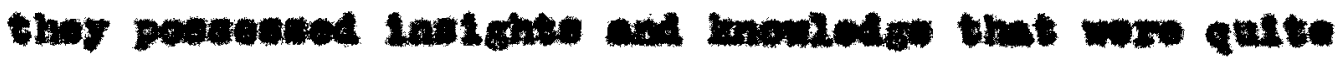

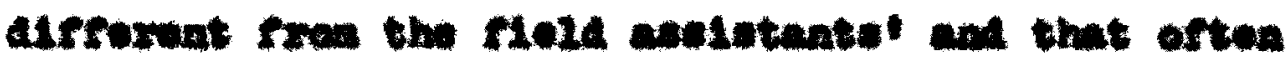

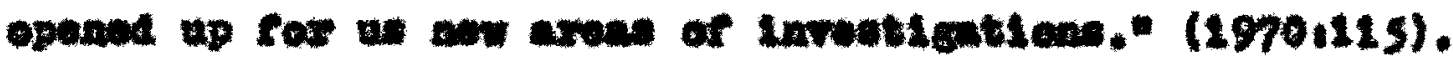

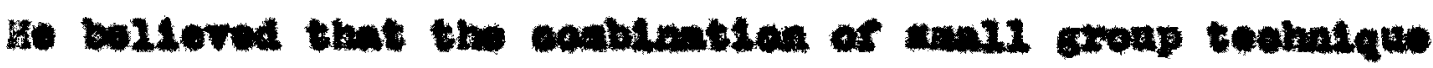

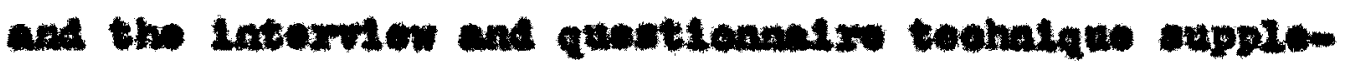

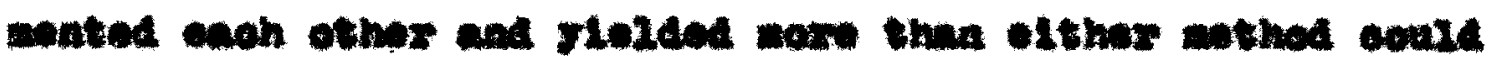
nave alone. 
Sohmb, It will be noted, also used a seleot, nonreprosentative, non-random aaple for his group. His boharlor with his group wes appervently sometimes that of nDUs-unall group convener or raoliltater. At other times, however, ho ellolted needed lnformation and holp from them.

Janes P. Spradiey in hls ethnoselenes atudy of the edaptive etratogies of urban nomads askod croups of in-

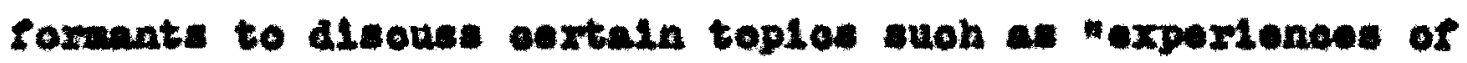

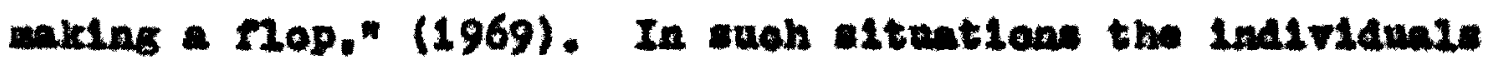
often talked anong thomedrex mithor than to the researeher.

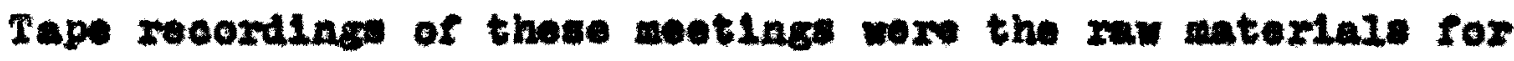
a counitive antegory aystens etuay.

\section{v. BROAD STATEMERT OF PROBLSH}

A. we have wentlened the ollnleal parehologist and ouluxil anthropologlat tond to viow bohavior Alfexuntiy.

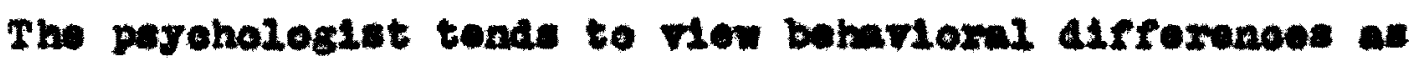
refleoting oonelow ar unoongelous motivations or nood of -posirte Individuale while tho enthropologist teads to con-

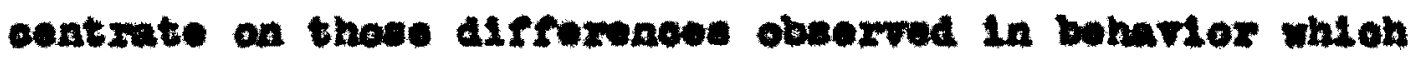
aro prianxif ascoolated with oultural conditioning. In this study a payohological technique is borrowed but the Vien of behariox is that of a oulturel anthropologiet pri-

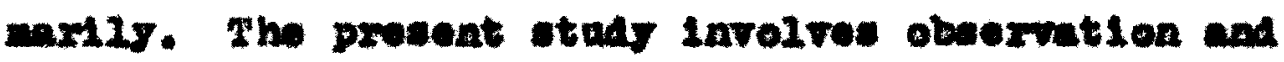

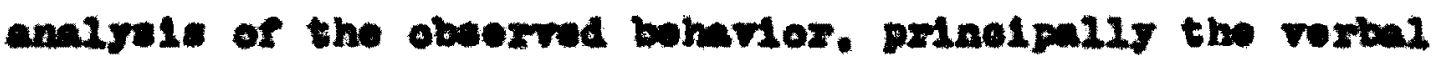
beharlor. of enall groupe of perwons rrom saudi Arable and 
emall groups of person from Japan. The boharlos exhibited In the Arab groups wen capared to that in the Japanose exoup in oxdor to detexing whleh aote of boharlor wox difforont and soomed to be solated to that whloh was apoolfloalis oultuxil and thaxefore of anthropologtoal acuosrn.

Tho boharior wthln the Amb eroups and the boharlox wthin the Japanose groupe wa alwo noted lnoldentally in oxder to dotermino that whloh wa due to an Indiridual's

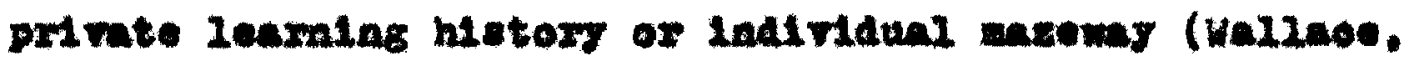
1963). 1.6. of epoeind sonoera to payohologlata. Indlvidua alfferonges within each group (within oach sroup as opposed to botween sxoups) although notod as belng of intervest to perahologiots wore not laterpreted or analyaed.

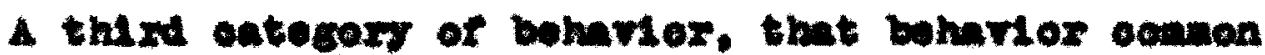
to both croupe we asoumed to be zolated to oono varinble pxosumbis in the prosent. arfoot1ng both groupe, zother

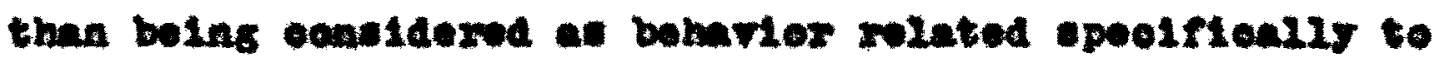
perohologioal of oulturml alfremenoen. As wa proviouely deseribed the HDHs-8G we weed with both groupe se both the

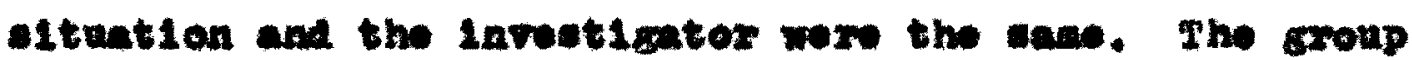
nonberrohip roquirowents wers hold constant also. Whan both

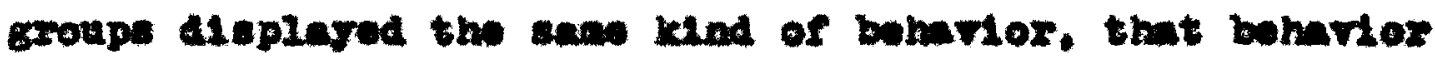

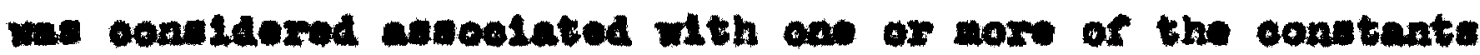
(the Mois-sG attuntion, the inveotigntor, the bielogieal human-pose of the paxtielpaste or the reot of tholx all 
belng Portland state UnIveralty forelgn students, eto.). The exact manner in whloh the boharlor of the Japanese and saud Arabs would be alike or different from each other was not possible to prediot. Given the two eleotions of Individuals from two ethalo groups, oertain fundamental differmoes would be expeoted, but what and to what extent. only the actual colng of the exersise could revenl.

It is asoumed that all othale group dieplay onrtaln bee10 attributes of thelr oulturos. One nould expoet that oren a haphazand selection of mombers of a given ethnio group would reflect sonothing of that laxger ethnse group of whloh they axe a part, and that those distingulahing attributes rould be exhlbited in the form of bohavioral Afferenoes between the two sroups. These differenoes in beharlor between the two acuples than were related to tho rladings of those anthropologiats who have etudied the othnio groupe involved by Alffoxent means.

It makes aonse to interpret ang of the beharlox patterne obeervable in wall sroups of the type 104 by perohologlate, eduentore and othor group facliltatora today an both the reavit of and a part of the greater oultural bakground of the Indirlduale involved. Inther

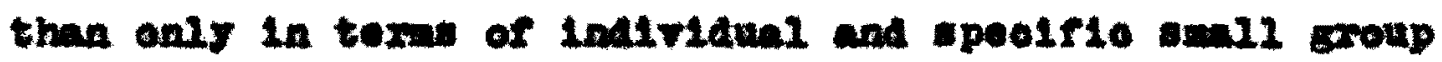
neede. An anthropologlet w111 any that reflectlon of one': oultural background would be obviows in anf small group but 
many invest1gators rall to note ite ignirloanos.

In non-anthropologloal reacaroh it has been usually Ignored or considered as one of the unoantrolled marlebles wh110 in reality it oould be one of the majox oontributing. faoter in undortandine hwan beharior.

Whan one constders the rast muber of amell aroup

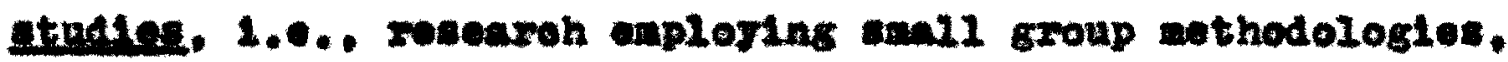
one aces that there are rittially no sall group otudies in the avaliable litexutare to elthor substantlate or rofect the notion thet alffervaoes in group boharlor we suoh axe assoglated with differwnoes in ethnie bolkground. For example. Mocmith and Altman (1966.107) in atudying in dotel2 evexy seventh seall group resenroh atudy fros a coxpue of 2,000 senall group resenvoh atudies found that in none of the 250 studies roviewed wa thore an atteapt to exanino

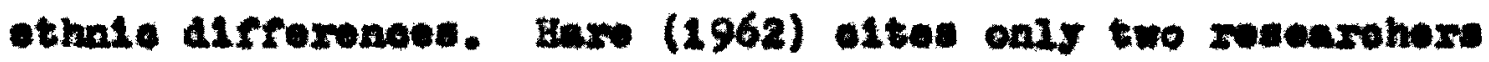
who have consexned thenselves whe othnle background, strodbook (1951), In has otudy of hubbua-nire intemetion In deoleson making in three oultuxes, and Grx (1951), In his pliot study of oulturel differonoes in an analyele of cosalttee anbor' boharior in four oultures. Thus, thie prosent study may sorve to partialiy 111 this Iacuand.

$$
\text { vI. SUMMARX }
$$

To sumonrise it w11 be noted that in this 
Introduotory ohaptes it has been stated that this Investigation purports to explore the MDusmso an an anthropological tool. The MDMs-so has ben deseribed a altuntion in whioh the invortentor inhibits himself frow diseoting tho sroup partiolpante. The altuation itaelf is ambiguoue or of IInted otrueture, 1.0. there is no ageada to that the group partielpants are toroed to drat upon tholr pormonal

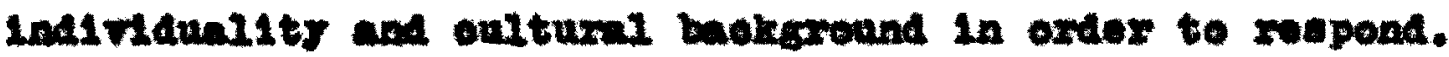
Thals behavior is thon obeorved and oatogorised inter 1) that boharios whioh is the was between the two eroups, 2) that bonatior which alfrereatiates one group from the othor

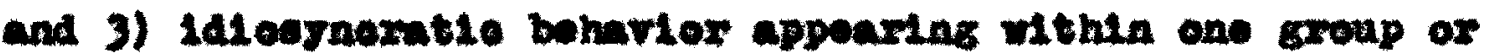
the other and asuned to bo rolated to some Indridunl poonziarity.

That behartor comen to or acoopted by nombers of one group bat alfrexunt from bohntiox caman to or cosepted by nombars of the othor group is then furthor oxaminod a belag of anthropolosieal interest. This boharios whioh Alfrezontiates the two croup is then related whon pousible to cate on the chareateriotios of the two oultures of orlgin of the unall group partlolpants. 


\section{CHAFER II}

MExHODOLOGY

It 10 diffienlt to formulate any tentable hypothads

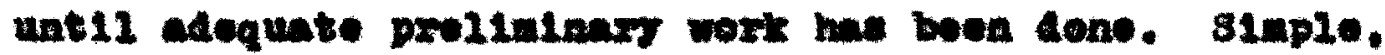
objeotive explextiory somenroh 10 a proxuquieste and the proesat otudy represents that phase.

In tho following pagos the nothodologs for both the

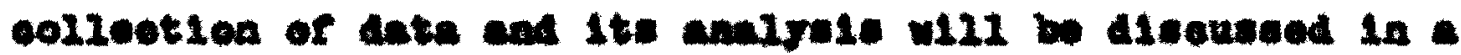

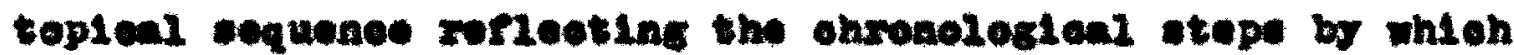
the study was dene. spoelal wose of paztioular torme and

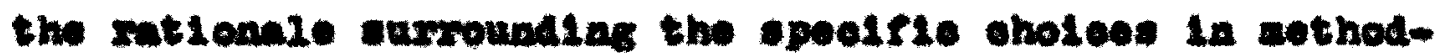
02007 w112 be explatinod. Dirrioultien oncountered wLI aleo be aleonses.

\section{THE SAMPLE gasscerton}

It is if oxide how to alcoune fint the seloction of the canple. The torn caple is wed hore in a atrietly anthomatleal soane, 1.0. as wone of a population. Thoxe

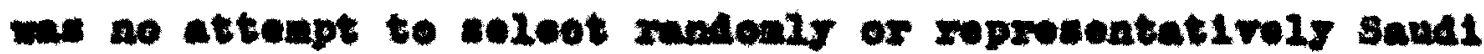

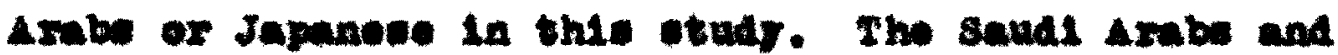

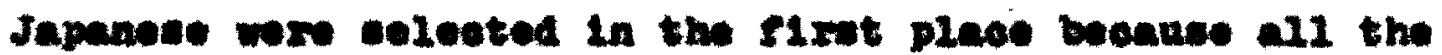
other ethnia croups reprosented at all at Portiand Stho

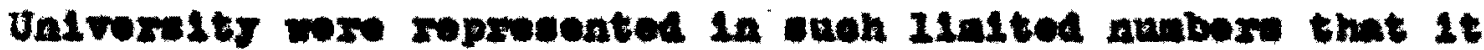


wa Impreotleal to attenpt to form a small group of any ethnlo group other than Arabe and Japanese.

By working direotiy with Mre. M. and Mr. C. of International Progrwas at Portind stete Univereity. P1rteen saud Armbe and firteen Japanose attonding Portland State Untrersity who, (1) could opeak Engliah, and (2) wore not onxolled in seme Portland state Univeralty olass at the meeting tian (arter 4,00 p.e.) were oontaeted by 1etter. Tho Japanese waxe told that a Kx. PLeree, a craduate student in anthropolog was writing hor master's thesis and wa Interosted in meoting the Japanose students at portiand State Univeraity. Sho manted to got to know then and wa Intervated in asrthlag thoy thought would bo

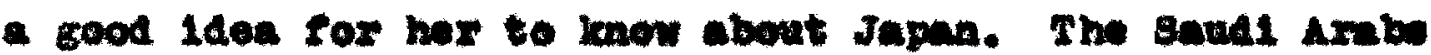
ware told the wame thing, but the words saud Armblen and Saud1 Armble were substituted for Japanose and Japan. Ther were told thoy would noet woeky for an hour for elx weoke at 4,00 p.t. In a peolr10 roca. Thoy wexe also told that this was not required of them by the sohool.

The Jeprnese who partiolpoted in the flret poting w112 be roformed to as amall group J-1. the J for Japanose.

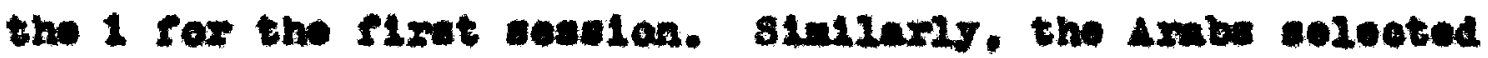
for the flect mooting wil be serexwed to collectively as anall group A-1. A for Arwb and 1 for the firvt ceeslon. (A-2 would then sofer to smb group, second ceoclen, ote.)

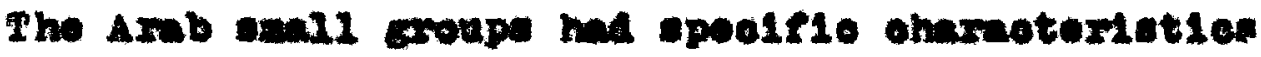


whoh distingatohod thos rros the Japanewe onnll croupe.

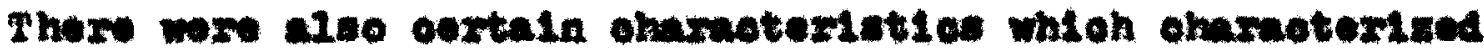
both croups. Thowe ax oharted in Table $I$.

All of the sumal Axwb lnow wah othor before ocalng

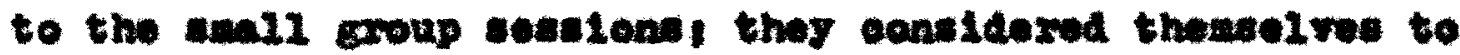
be Arabs, thoy wore all born in Saldi Arable and they wox. rndeod by Arab parents. Seme were ofty urod and same waro of nomale bakkground bat all wore Inaletent on the fact that they wex uated and Arwb. All of the Japanges know enoh other bafore coming to the amall group vesutens, they considerud thouselves to be Jepanosel thoy were born in Japar in olt1es and saleed of Jepanese pareate. All of the etndents involved in the projeet had been in the united State of Aevrloa between one month and throe yoarw, all of thom expected to wotarn to thatr native land to thoy all ware teapornxy restente hore on atudent rivas. Mone of

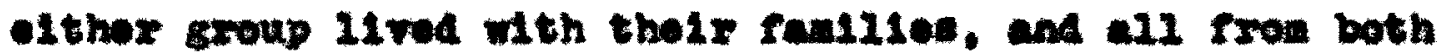
groups had been or were enrolled in apeeled Inglish for Porvign student prograna at Portlend State UnIroxalty. All wore botween the ages of elghteen acd twonty-a1x.

Aotual attondanoe howvor of purtoular individuale varied froe wak to wok. In tapt twien tho Axmbe brought gueste. Thoy brought a roxiean strdent to the firth soselon. and ther brought an Arob fron Kumalt to one of the meotinga. Mr. C. a monber of the saniniotzet1 ve otarf and Inetrunentel in soourlas the Amb informante roquested 


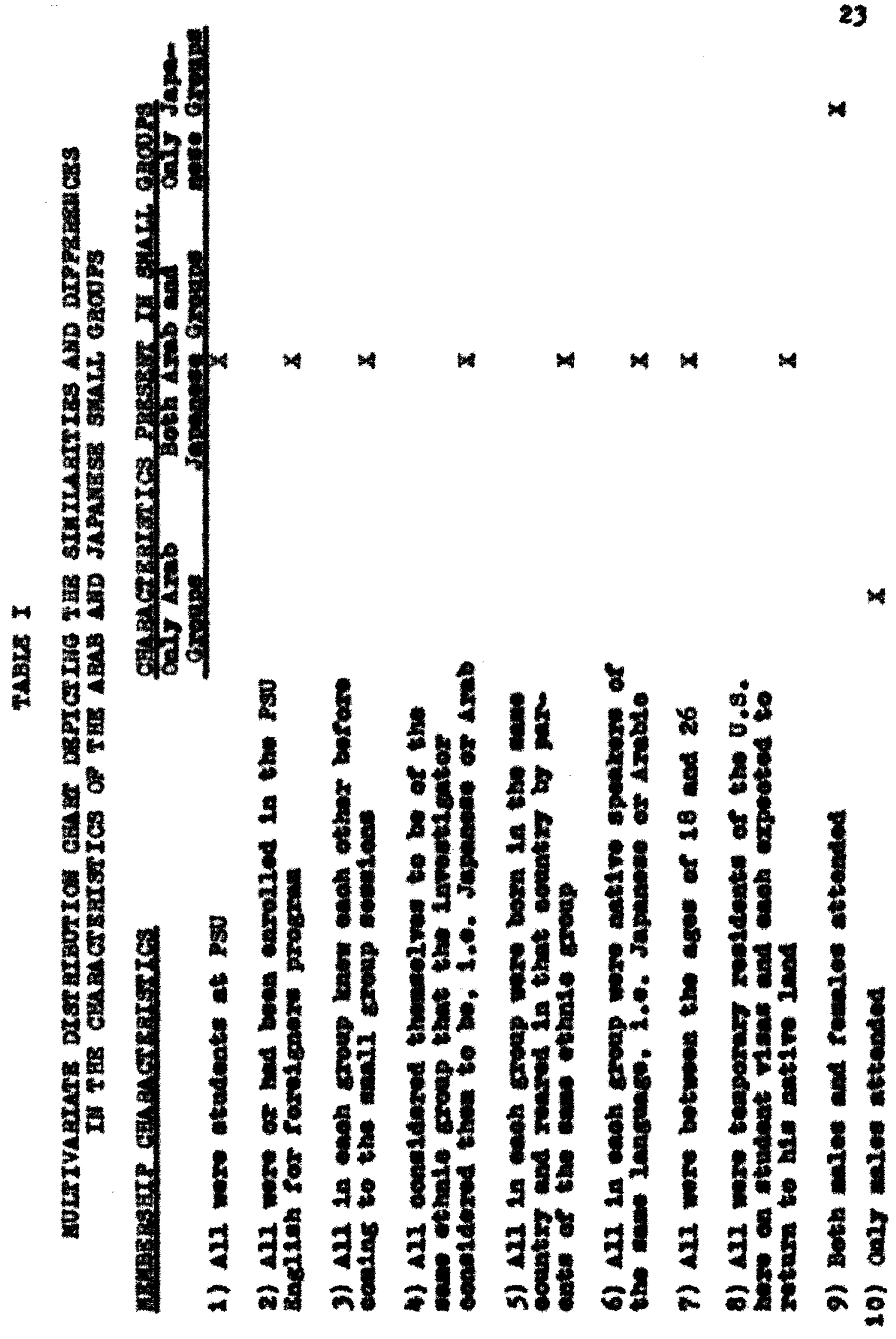


peralestion to observe part tine during som of the Arab eosulons. This nequent wanted. The erfoot his preagnes had on the data mut remain an unknown. Hi. verbal partiolpation wa alnimal, and no partloular change saseolated wth his appourting of loaving could be noted by the invoutigeter.

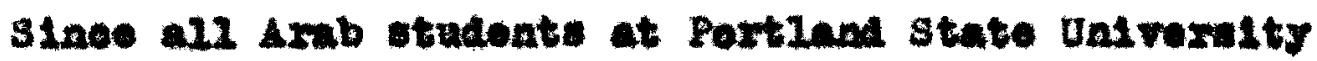

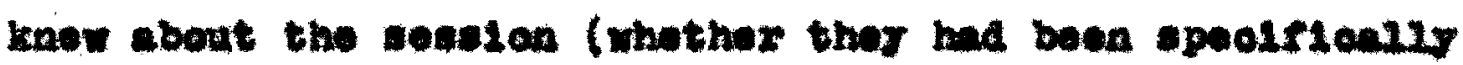
Infited ox not). and all Japanase know about the Japanose cesctoas. ans of elthex croup who wot the requareanents of

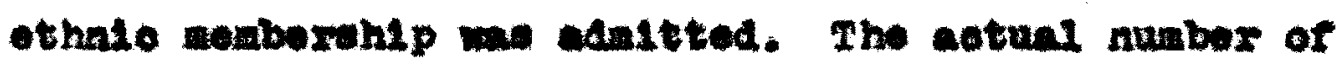
people attonding cosstons varled frem a mintun of rour to a maxtaum of alxtoen.

Undoririns the aseoptanes of the fuot of interalttent moaboxwip is tho asuaption that indiridual within any othalo sroup ar metualy subetitutable for eaeh other if all Indiviuns oonform to the requirwante of mobormip for the anall aroup.

It heppened that no Armb fonale nould consent to come. The forelgn atudent rooter at portland Stato Univexstty rex the spxtas of 1969 mowe that 100 than ono-ninth of the Arabe wre romile and woxe than one-thixd of the Japanese were fomale, wo one wight prodlet this posalbility. This reature too, hownver, oovid be inter pxoted an due to oultwral coaditicating a unnerried Axb men and women are rwxoly aeon togethox in publis in 
Sandi Arable.

The fast rowins that an additional unoontrolled variable we varoldably added-that or having the Arab sall group all all, expopt for the Investlentor and the Japansec amell group mixed. It It unfortunate, bat in this ease an unaroideble happening whioh oaly furthor researth can oomeot.

It 18 Impoxtant to oxanine theet almilarities and diffenenoes which will in the future bo termed aedbershtp requirenonts bounse Iater they $w 111$ be contrasted to the - inilaritios and difrexences enoountered in the rerbel. behartor between the two groupa.

II. THE PEYsTCAL SEXTIHG: THE LOCATIOA, FERQUENCX, AND BOUR OF KEETING

Enpty Foene at Poxt1and State Unlversity were soarce at the tive the rowearoh wa oondueted. The rook finaliy

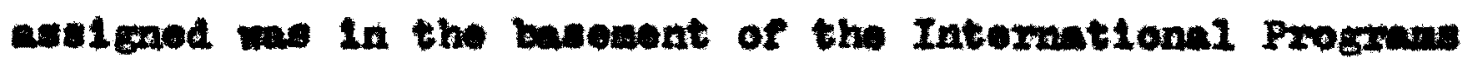
bullalng, a bullalng about to be tom dom, It wan abont twelve reet squire with a door at one alde and a wintew raciag out on a buag etxeot on the other alde. It was unued except for storage. eonseguontiy it wa nolsy. oluttored and dirty. It's prinelpal adrantage wa 1 ts proxialty to the Internatlonal Prograns offloe with which all the rorulgn students ware ranlilax. The question of how orten they should meet was 
xolated to the oholoe of nathod of analrs1s. 4 body of material wa noeded. If it ware too big it would be unweldy, and if $1 t$ wero too amall it would not provide adequate data. Thore wa no wy to dotexing the optinn number of eoculans pritor to explotion of the projoot. It wer deolded that ali mootings would be held wth the Jagmnoce and Armbe xoupootively and that olx nooting oas would orfor a sppotitive ohook. A preantion wa than twren by coing it alx tieod. Ang alptake that ooeuxrod

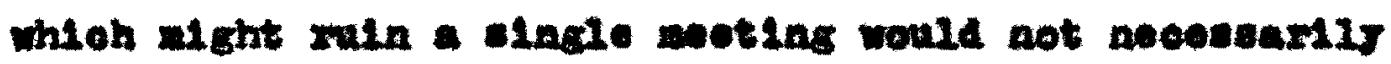
rath the projeot.

A. wth the we of ar projective toohnlque. thore we a wde Iat1tude in rospone oxpoeted. Bopotition of

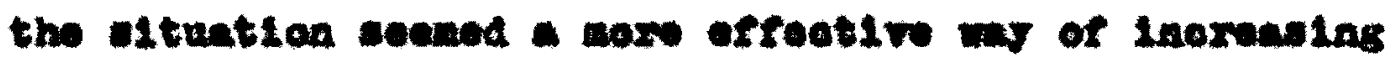
this Iatitude, thareby providing the lavostigeter wth a breador view of the phonouveologieal world of thowe inrolved. Thm thow wa both a 1axcer rolum of Information

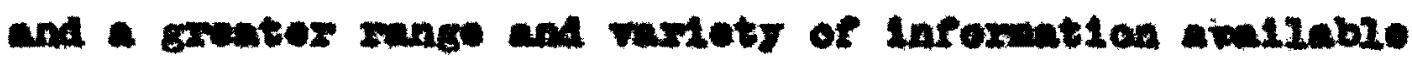
ror analys whout meort to opeolfie olleltatien. The hour betweea 4,00 and 5,00 p.a. wa busgonted beeanae conAleting olne chadulos wox least likely to ooenz at that houx. If it had beon later, the andiember alde dopart-

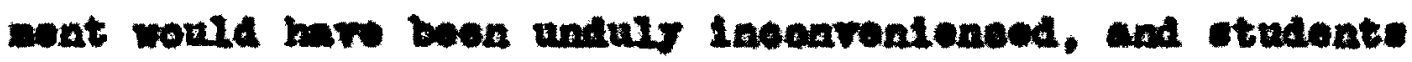

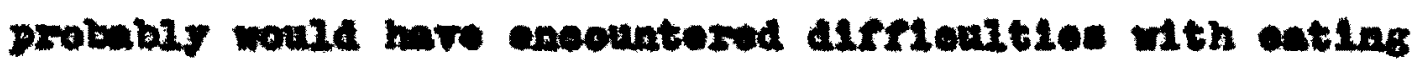
arxargenente and tranaportution.

In sotuality those groupe of Amba and Japanote wex. 
studied in the spring torw, 1969. The wescloal were epproximately one hour eaoh. Bech Japanese Eroup aeselon

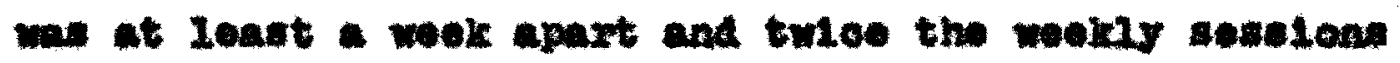
were poetponed or canoelled, onoe becaves only ane perwon oame and onee at the regueat of the partlelpante for

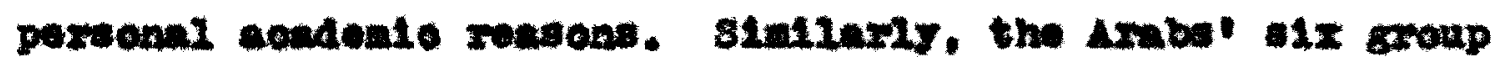

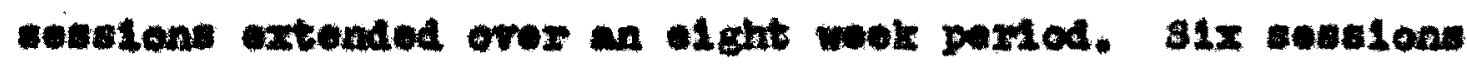

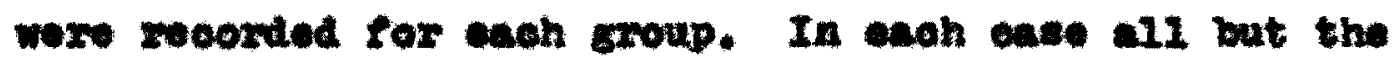
firth seasion took pino in the Pextland stato Univereity

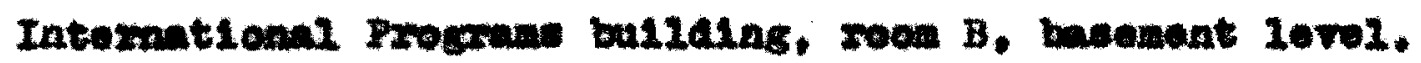
The fifth session teok pine in the how of the Invertigutor at the arcestion of the Intoxnational Programe adninistrative otact an a token of eppreolution to the

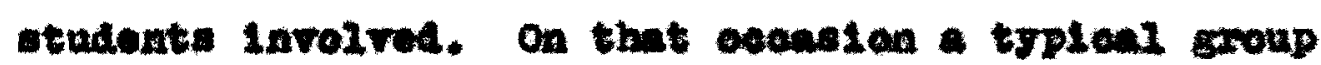
cescion we mold, bat befoxe and arter the weonlon the partielpants wax entextalned and sexved refroemments.

III. HBCORDING IEE MATERIAL

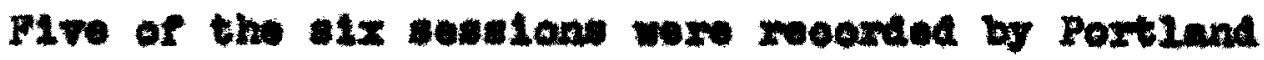

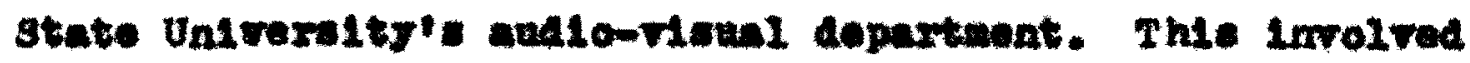
the prosence of an oxtro perwon wth rovording equipment and morophones. In owoh sace the teohnialen ald not inter-

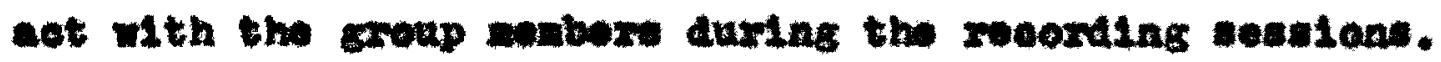

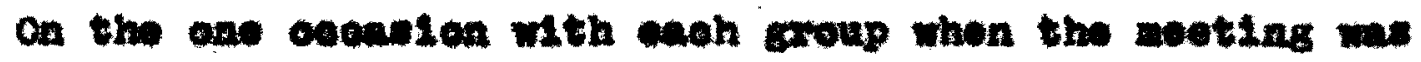
held in the Inveatlgator's how, the roostling wa handed by the group frollitatex mather than by the audio-risual 
dopartiont.

Recordings wore oonsidered neodimery in order to reduoe the Ineritable distortion that oocure through seleotive mowory. Thoy also rendered it posmible for othars to ohpok the lavestigator's coumoy and objectivity. It should be noted hare thet desplte precautions taken the tapes wox not totally intelligible. Bmoksround nolven. the faot of soveral poople talking elmultanooundy, Alfroultios on the paxt of the studeate in uelag Bnglieh, and In ane onse a malrunotion of rwooxding apparmtus all contributed to this diffioulty. Eloven of the tweive tapes wore between 95 and 98 pereent traneoribuble, but the tape of the fourth Japanose seselon we almont totally Inoouprom honolide. The tape ware not now and tho rooording heed in this oase falled to exace all of what had proviourly been

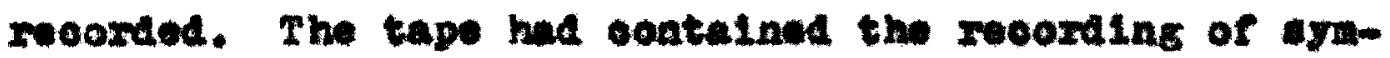
phong and tho exnet wond of the Japanone group neabera wore barely audible through the muste. The malfunotion was not dlaoorered ant11 the Investigntor we transerfblas the tapes werexul woole after tho sotual roooxilng had beon sade. Bxtensive notes had boen taken as uswal imoodiately arter the seenion in quostion and proved Invalabile in

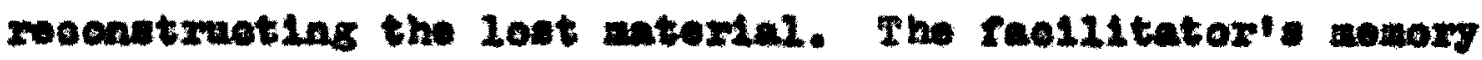
of this cension we oheoked in Inter cosrersation wth three of the exroup partielpants. 
wrote up what had oocurred within the group sotting. origlnaliy the note taking activity we doslgned for the imodiate on-golng pexwowal we of the inventigator. SInee a tape reoorder was not readily avaliable for listening to the taper between sesulons it was to the faoliltator's adrantage to have a readily acoagelble conventent sot of notes to refer to pmox to oneh sosalon, about provious

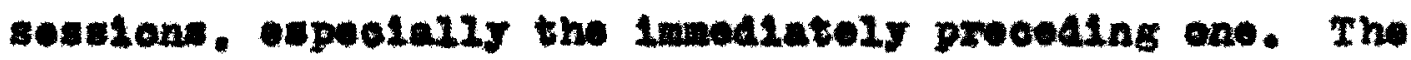
notes Included atatements ebout who wa thore, and who sald what or soted in what wy. Sowotines a desoription of tho

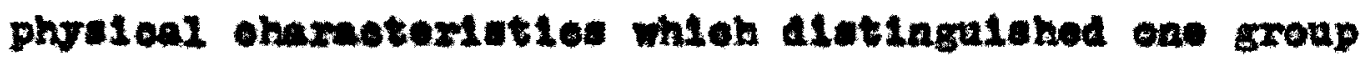
nember from another in the ores of the inventigntor was inoluded. This helped her xomomber the partlolpants as

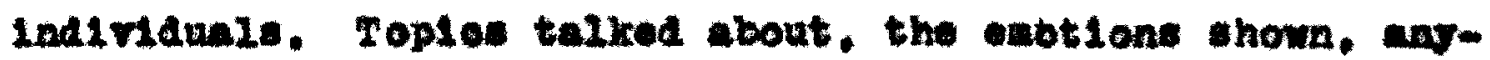
thing that lapresed the Inventigator we elther worthy of note of as somothing to look into or ohook on mas jotted down. Somotines the notes elmply Aupliented what was latex to be transersbed fron the tapas. Obeaslonally non-rooul beharior or rerbal behavior related to the session but ooduring Imediately prior to what was belas rooorded or Imediatels following it wa inaluded. Ihus, these notes and the tape reoordings conntituted the totel reoord ox cerpus of material ut1lised we enta in this inventigntion.

IV. SKALC GROUP CHARACTERISTICS AND TABIR RELATIONBHIP TO THE ROTE AMD/OR BEHAVIOR OF THE GROUP FACILITAT OB IN THE HDU8-SG SITUATION 
The rolationship between the faeli1tator's beharior and minimal direotion-minimal struotuxe have been disouses briefly in chapter I. The only tines direotion and atruoturing were attempted (and then minimaily) in this utudy was when the anxiety or infrequently the ourlosity of the Investigator eade it seeningly imporsible to refrain from 1t. Por exmple, when things were so boring that the investigator reared the group webere who ald oome would not roturn, ahe would atruoture in the psyohom

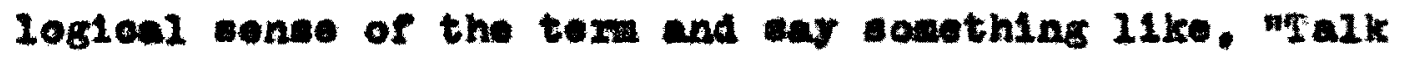
about anything you'd IIre to talk about, anything about roureelves or jour oountry that rou think I uhould know or would be Intereated In," or "Palk about what rou talk about usually, only talk in Baglish,"

It 111 be noted that in amall group work there are a number of variables or oharacteriatios whleh an be Influenoed and partially anipulated by the group convenor or racliltator. He oan infiuence the lovel of partiolpation. 1.0. he oan eubtly or obrlouely ahift the lorel frou abetrat to conerote or from Intellectual to omotional or voe verwa. Many ourront gxoups strive for what 18 samet1men reforrod to as "gut-1ere1" partiolpution. For oxanple. both tho old and now etyle Bogerlan eroupe and tho groupe patterned after H11I's Intermotion Matrix (H111. 1962) plave opeolal vilue on exproustos foellag and on getting nore pereonaly involved of gettlag lato deoper 
moxo "geaningful" matorial. Thore was no attompt mado with - Ither the Arabs or Japanese to aohlove any partioular lorel In this study. Instead the 2nrestigator noted the 10vel and did not ane any atterpt to ohange it. Bxistentialiy oriented groupe (Buber 1959, hay 1959) todey tend to strese the "here and now." The earliex paychounalyt10ul groups (Wolf 1949) stresed the past. espeolally as It rolated to the present. In the prosent study, both the $A$ rabe and Japanese wexe told that the Lavestigntor wanted to get to know them and to Iearn about their country of origin. Thoy woro asked to just talk. Liniting toplos of apeoch to 11scuestion of aotions oovurring in any peolfio tine period such an the presont, future or pat wo conalderud inappropriate because it alght be too western-oviture oriented. Intensity and unirerwality or Involvenent are two other cheracteriaties whioh oan be Influenoed by the faollitetor. The an Interoultural Commalention Woricwhop training groups (ICWs) (Claxk 1970) have wa ono of their goals the involvomont of each and every paxtiolpant in a group. Sensitivity group alfer in that nowally partiolpante deolde for thomelves if and when thoy 111 verbally part101pate. In both the $\Delta \mathrm{mb}$ and Japanese sanll groups. group nombere wero encouraged to partiolpate but partiolpation wa not an objeotive. The Inveatigntor might nod at a partloulariy quiet mowber and any $m$. . . and would you 21ke to add anything?" or "Bave gov had an experlenoe like 
thatf" While atrong soletanes to partielpation masxoapoted, partielpation we not left entirely to the 11:axetion of the croup mosber. If thowe present KDKs-So's were to be xunked aleag with sonativity group on the loft of the ceale and ICW's at the $21 \mathrm{ght}$, they would fall to the right of the widale.

Thare wat as attoupt ande on tho part of the croup

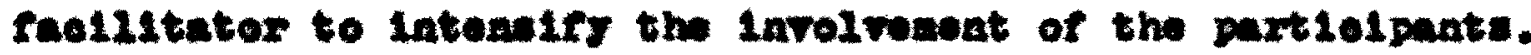
Ievele of ancioty an conotines be purposely inoreneed or doexeaned by the group taliltatex by using varions teohnlques. Whon anxioty we arouned in rouponse to sotions of the rasil1tatex. It we govezully for the purpose of alleming the renpenibility for the topled of conrowation to ston fron

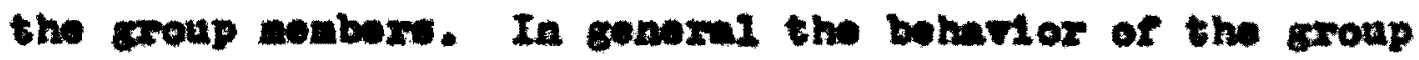
faoll1tator wa warn, acepting and didy supportive. Suoh things as "ros, I bellowe I ean understand that" and "Den't worxy about rour Bngl1h, 1t's 0.K," were sald.

The bullalns of trupt and triendehtp anong sroup nonbers is conoldexat as an inportent objective In ICW croupe and Vationi rralating Laborntory (MTL) sroupa, as

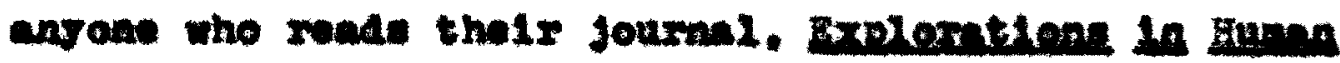
Rolation, Irining and Barewh oan attert to. Thax are - number of known exeroleos whioh raclittate thie. In the prosent study, no tine we deroted to the dovelopent of this mutual undorstanding. It we not known how ladividn10 with a difrorent eultural bokground would roupond to 
exorelses suoh a thle, and it wa outelde the roaln of the provent etudy to rind out.

Bnoounter or canfrentation wex nolthar explieltis: or Inplieltiy condoned by the reollitator al is the oase In many earment groupe. Thase an have oocurxed in the

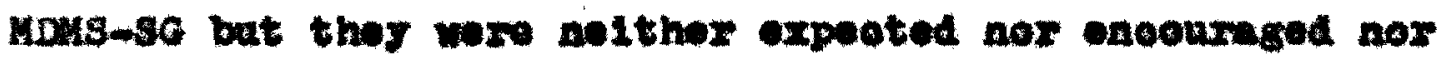
Aleoouraged. Those Intexnotion teohnlques used wers appaxatily both raniliax andox comfoxtable for the partiolpente. Yo intormation wa interpreted to the group by the Eroup faollitater and no one we oncoureged to tall hew he

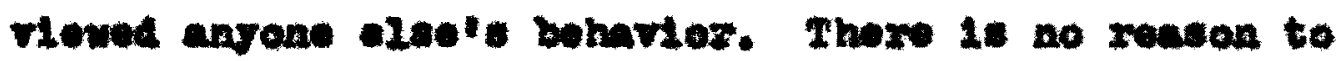
bel1eve that the partiolpante involved in elthar the Axub or Japanea croape did not Intermot following a pattern conoleered appropriate in thels oun submoultur.

It w11 be noted, then, that the boharlor of the

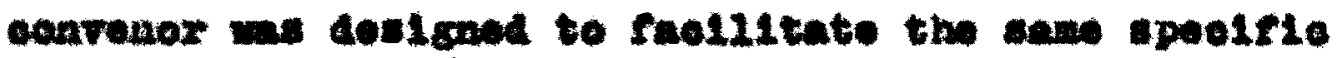
ohnmotertetio in all the wovions with the Arabe and in

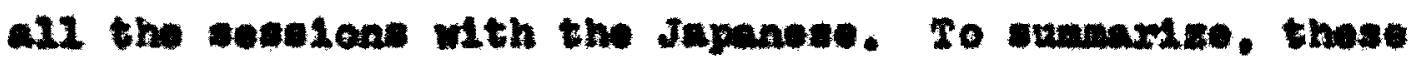

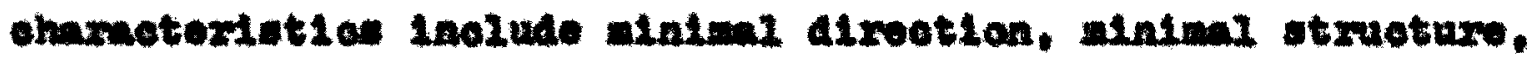
a noutral attitude toward confrontation and enoounter. andial wee of toohniques for intenatriation of involve-

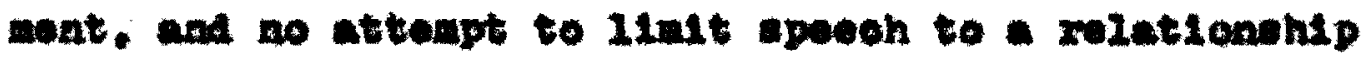

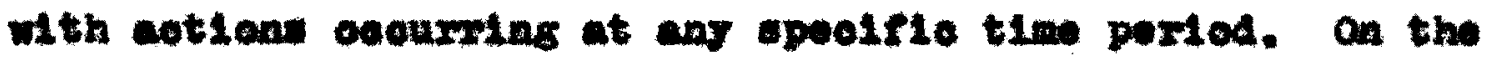

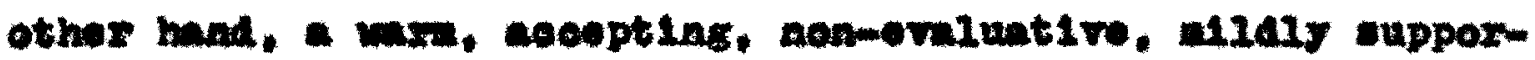
t1re stmolphore we oxoated and sowe attompt. though IInited, wa mat to engage all sroup monberw In verbal 
boharlox. Wo emphese wes pleoed on devioplne autial trust between sroup nombers nox was epectal ralue placed on achlering olther the emotlonal or Intelleotual level of Internetion.

V. THE METHODOLOAY BMPLOKED II TEE ANALYSIS

The rDHB-se provided a stuation in whioh those croup moxbert wexe froe to ohoese tholf om toples to talk about. to axprose watever anotion thoy ohose to exprese, to Internot wth the group fadiltator and wth woh other In whatever wor onlted thom, and to organles thangelves or not as they ohout. In the proeser, thetr reactions to the eltuation were obedrwale, and a body of material wo gathoxed ror analyale.

The olosed coxpus teaknlque, a sothod boxromed rrom anthropologtoal-1inguletion, It oultable for the analysis of data saoh as thls. The teohnique lnvolves welng all of - gathered bods of Ifformation and nothins outalde of 1 t. In this cere all that wa Intelizgible in the tape rooont-

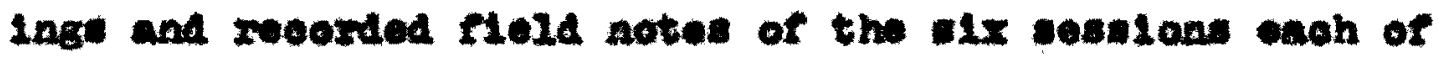
the Axb and Japanewe croup constitute the total olowed corpise. One of the oharapteristion of this teohnique is that one fores himele to handis overy sentence of utteranoe in oxder to avala clatortion by aleotlon of anly thoue Items which would strongthen ax-oonosivad Idea frow within the deta. In this type of study the 
investigntor takes the new unolarelfied data and studion it

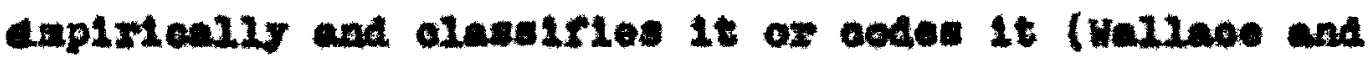
Roberte 1963:129) ualas a post ontegorisation systen (Horas and Lippott 1954.399) abcording to whatever Inhorwat order the data londa itself. Port sategorization is a toohnique of developing eategery arston in the proeses of atuaying cone sort of total xosond. The analyet thon aoourately

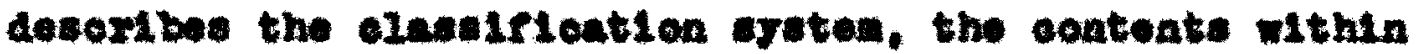

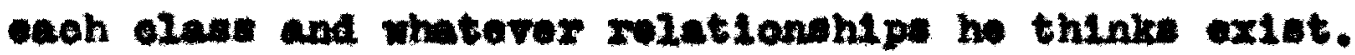
(Harma 1951. Plexe 1970). Its pxinaipal admatages axe, (1) It reduces the aumber of raxiabled on worto wth and (2) It objeotifles cats in that the intervet of the Inveat1gator does not oontrol the veleotion of materiels to be analrzed Hnoe IIntted begment is completely annjyzed and

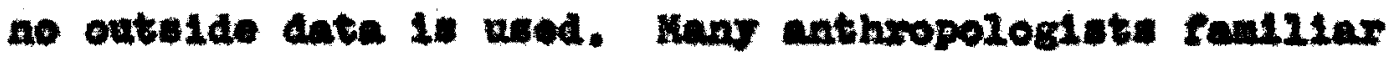
Ath the nothodolos of atruotural Iingulaties have applied Closed corpue analyis (Soln and Dundes 1964. F1ke 1967. Ha11 and Nottio 1955) among others ues it oonelstent1y. With reapect to the provent atudy, by welns the alosed oorpes tookalque one way 16oldte boharior whioh ocours in both the Arrb and Japanese croupe and antue that the

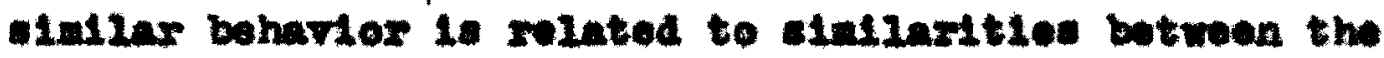
Arabe and Japanese group anmers suoh ws the faot that they aro all Portland State University forolgn atudonte 1iring awny fram howe. Secondy. br usling the teohnique one mar also laolate both the Afferenaes within the Armb group or 
within the Japanese sroup. If one Individual only displays a certaln trpe of beharior (one Armb stuttered), one an asewne (although not prove) nocossarily that it is an Individual poouliarity, and if severmi diaplay it, it 16 probably safo to assume that it io not an indirldunl poouliarity. If oertaln boharior 18 apparentiy nooptable to all group monbere and displajed by all or moverml sroup nombere. It 1s probubly anfo to tentatively aseune that it 1s both oulturally appropriate and not ldlosyerntio behavlor. Thiraly, one oan laolate that behavior comon to the Armb group and contmat it to the leolated behavior common to the Japanose group and thoxoby note the differonoes in the verbal boharior botween the Arab and Japanese onall groups. Tho torme Japanose or Arab oulture w111 be used hore in the sane sone that coodenough (1965) and Sohnolder (1965) spock of Amortean and Yankeo kinahlp terwe. It 1s part of the working hypothesis thut alffer encos so isolated w1Il bo due to one of the following aotuil difrozences botween the Artbe and Japanese seleoted, (1) culturel sonborshlp. (2) nox, or (3) somo othor unoontrolled vartable about whioh wo know nothing. There is of couxe no way to prove conolueively that the Alfrexenoes oberved between the two groups are eulturally derived. One oan, howevex, corrolate what one find wth what is knowa about the onltures in question. 


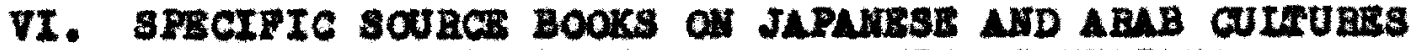
UEBD FOR COMPABIBOA UITH BEHAVIOR EXHIBTEDD IH THE amult, GROOPB

Both Axbu and Japanose have beon otudiod by anthxom pologtets. Becanes of the enormity of the tack it was ceolded that a lint would be pleoed on the atudies whioh would be unod for the mevearth. Sorexal books on Japanowe opltuxe ware weleoted as prinelpul wourees for ocaparisons.

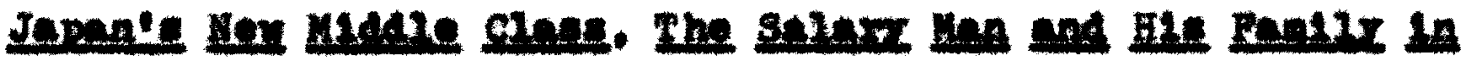

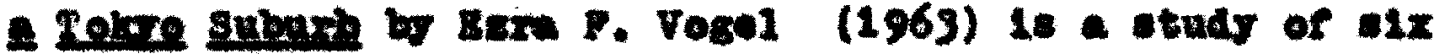

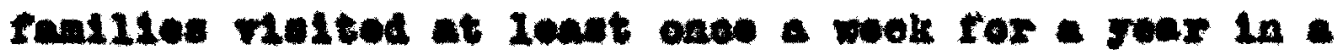

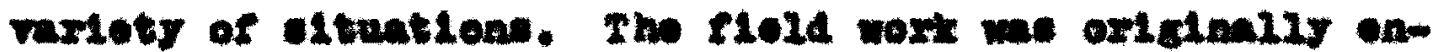
gaged in to dotermano Japanoce ranily pattorns in oxter to oontinat thone with thowe of other othat croupe. It was part of a Iarge studi under Spalgel and LIndkhohn of the Dopartmont of soalel Belationd, Earvard Unt vexulty. Thlo book wie perthep noet userul ar the aeleation of peoplo

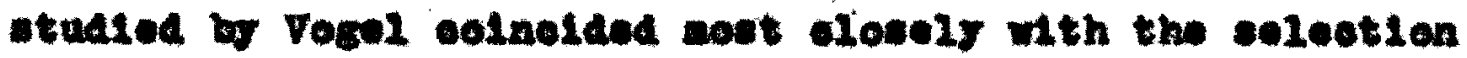
of Japanoue parsone in the prosent otudy. The Chroenthonen and the smont. Patterne of Jepanes culture. w Benodiet (1946) was aloo dhosen es it is an anthropologloal oluante and an exmple of atud of Japanose oulture whon a Nelt to Japan wa Imprection on

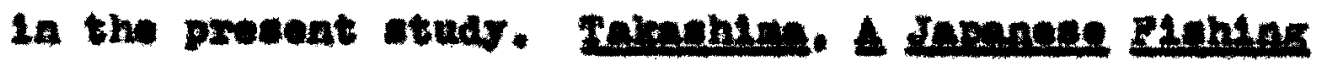

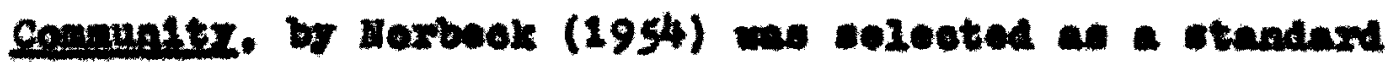

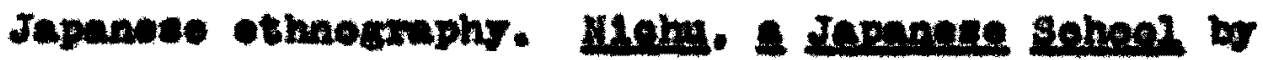


81ngleton (1967) If consldered by the anther to be a modern otbnolog of a sohool. This is a Algrosalea fram the oonrentlogal 1deal of whet conotitutes an othnographlo stady. at 20 the present atudy. Finaly. A Durchter of the Benurd. by Etou Inagalu 8ustnoto, an antoblogrephleal cooonat (1928) by a former Japanose language and history Inatrater at colubble we werul.

Beleoting anthropolesteally orlonted booke about sagdl Arabla wa nors diffiealt. Thore are no othro-

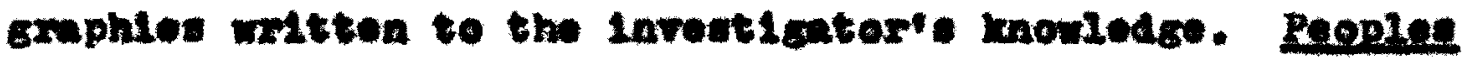

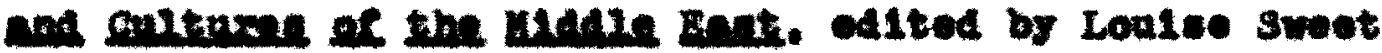

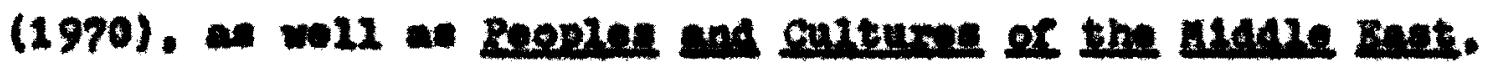
br Alloa shiloh (1969) (ane title) ar oolloptione of artieles on the anthropolos of tho Midale Eant. I fow of tho artioles in each pextaln apeosfionily to saudi arabla. Those which do are for tho wost part problea ortented or cover ono

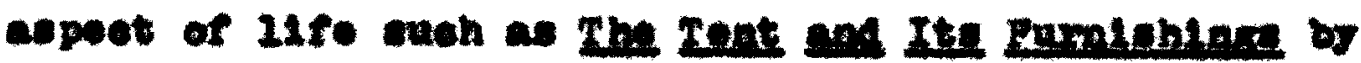

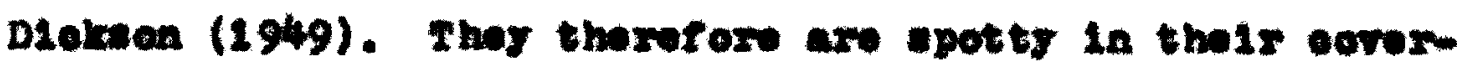
age but fron the panaty of avaliable data woxe need douplte the foot that thoy ald not lond thonelves wall to - compariaen with obmozratiow made welng the MDMs-80.

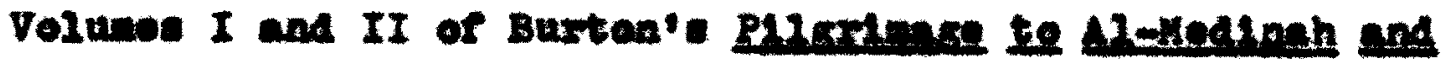

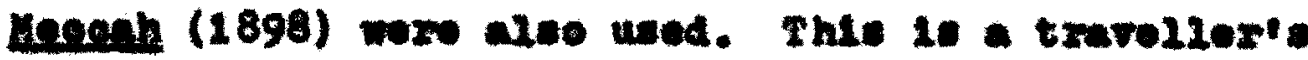
acoovat and he leng been oonalderve enthropologlenl2y

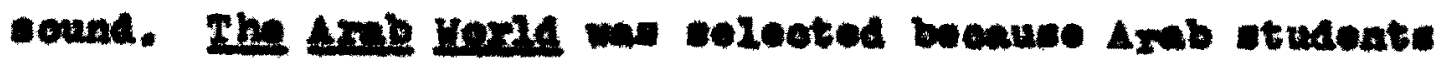

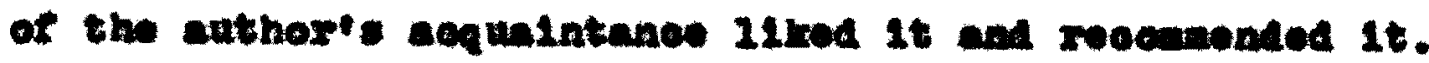


Coon's Garnan (1958) is a atandard anthropologienl text on the Hidale Eavt. It and servexil other referenoes portalining to Armbe in and outalde of sond Ambia wi2 be olted.

One of the prineipal problom in atteupting to rolate the rosults of the pronent atudy mith that of other atuales is that the atudes thomelved ax inecaparable, therefore the elesses of rosulte do not ovexlap. By walns only those 1tom on which the Arabe and Japanose differ, the laveatigator 18 ot111 left with 1teas which ho know through his experienee are trploall Amb or Japanese. but for whioh he eannot find mention in the othnogruphien. (The invostigator wa a rusident of Japan for one jear and of the Middie Bast

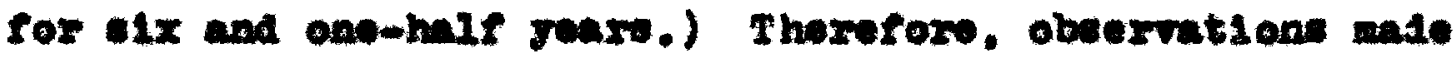
In both Saud Arabla and Japan by the Inveatigator w111 bo also olted when applienble.

\section{SUHAFE}

To sunmarise the toples ooverod in the ecthodologieal

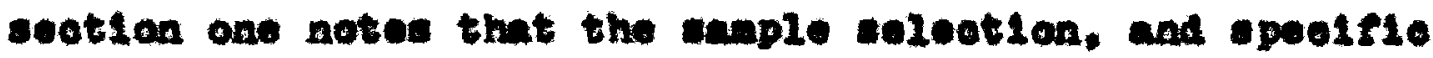

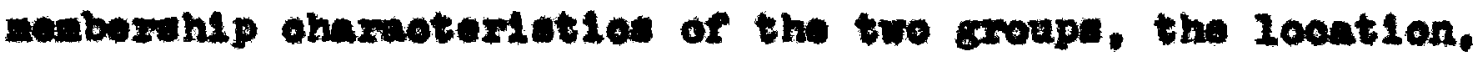
frequeney. and hour of mooting. as well we the reoording of waterials wexs all explalnod. Thore was alsousalon of both

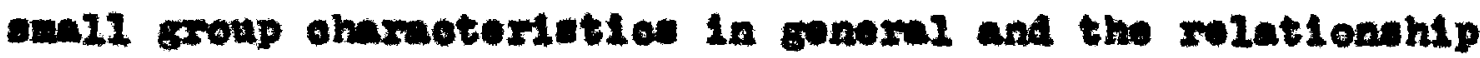
between those oharnoteristies and the beharior of the group faoliltator. Thos conomiltios woxe in turn rolated to the spoolf10 MDMS-8G eltuation with the $A \mathrm{mb}$ and Jepanese 
otudente in thie present invewtigation. other detingulehIns ohmreteriation of the opeotrie sroup In question wore dotalled. The olosed corpwe mothod was deflned and 1 ta specirlo applieation to the date cathared by the HDAs-30 teohnlqued we explatied. Finally, the Houres books on Japanose and Arbb exltures uned for eaparimon with the Afferantial bohmiler axhlbited betwon the two groups wor mentsoned.

To roviow, this atred is an appliteation of a perchom logleal sxoup teohnique modifled and used to underetand the verbal and other boherioxal phenamen exhibited by two "oultural" groups, ano Arab and one Japenese. An attempt 10 made to 1solete what is Alstinotivil Japanees or Arab by dolng a elowed coxpus analyela of eneh not of group serelons and thon oomparing the bote for aldilamties and differonoes. The difrerenose are then celeoted out for oorrelation wth Information gathored about Armb and Japanose oulture frow other courees, One oan ut111ze the woxking hypothese that the Amb group 1211 opontaneously

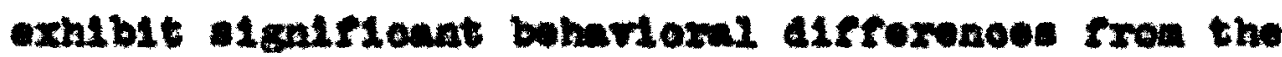
Japanose sxoup under Hors-SC conditlone and thet those differwnoes will be related to the othnie bekground of that lareer population of whoh they arw a part. If the two groups are substantially alfroxont and the differenoes are In the Alreotion of the alfrexenees between the two ethnie groups frea whioh thay ouse, the ascunptlon, wh1le not 
proved, w11 be abstantially strengthened.

In the following pages these eindinritied and affer-noer between the Arab and Japenese amall groups w11 be exaninod. Their ayoten or organlsling thewselvos wthin the group and the interaotien patterne thoy exhib1t will be

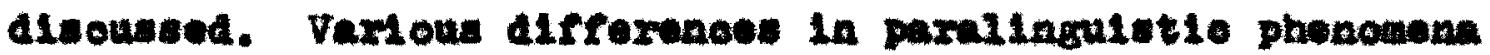
w11 be noted. The emotion whloh ther dieplay wi11 be

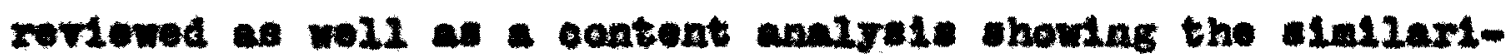
t10s and alfrexonoes in the materlale talked about by the two sxoupe. 412 of the above differwees w112 then be exeutnod and related to work by other researohar who have studied the enlture of the countries of exigin of the partiolpante in oxter that it my be posible to show whether under the KDMS-SG eonditions, anple wil glold the ane or a difforent type of Information. It whould boted that the toplos to be difoussed which are antionod in the provloul paragraph rosulted frow the post oategorization proeses and were induatirely derived rroa the data. 


\section{CHAPISR III}

\section{DATA AND AMLYrsis}

It w11 be ronombered that the prosent study is an axplomtory atudy. Thox wa no a prior list of Alnonslone or anpets to be obserwed, the ategorlas wor. induetively arrived at during and after the procese of

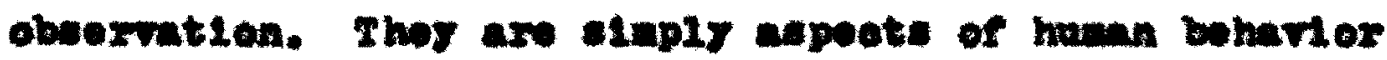

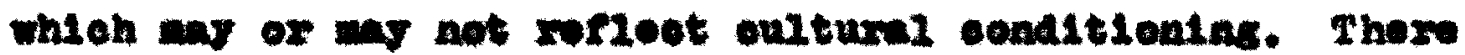

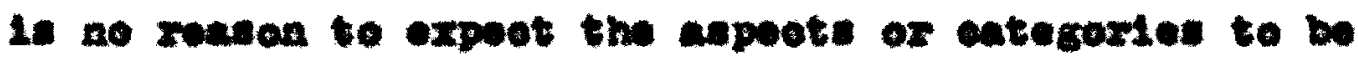
Ielated to each othox. Thoy woxe thore and wox obeorved and soported on. For dldatlo parpeses however one can

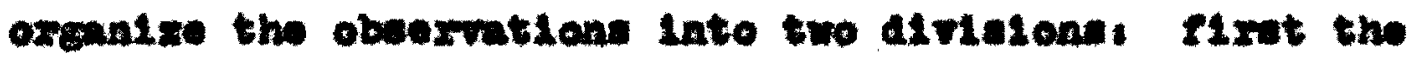
nox Inoluetre altwatlon extented oberrmations, and

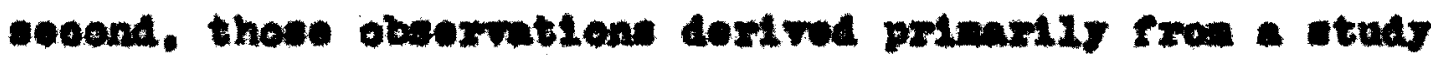
of the tapes. The fomer asn be nathor alvided into observetions of the gxoup wanbors rogotions to these

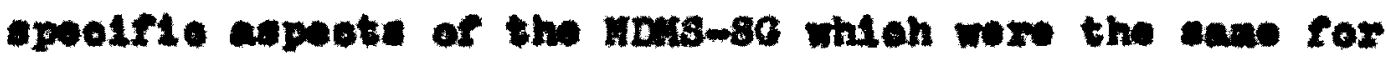
exoh eroup, that is, the wooting arxangenents, the tape reooxder, the tape toohulelan, the roon, the linlted etrueture aspot of the KDMsusG. ote. on the one hand and the cxoup': wothod of orgunizins ltoelf on the othor. Tho eapeote 111 be decoribed in dotell Intex, but to give an overmall pletwre to the roader thor w11 be 21 sted 
here now. They inolude parailnguletio oberrations sede on the two groupe, an anlyale of tholr Interaction patterns, a llating of the exotions expressed in ewoh group, and oontent andrela whoh laoludes a disouselion of thelr problows. In wah are the entiro oorpus la examinod, and the group are compaxed for almilaritiol and oontratted for differenoes. In the following ohapter, the olmilarities axe then related, when posalble, to eltuations comon to both groupe and the atreronese to thalr othnis beokgrounds.

\section{THE SITUATION-OBIEMTED OBSEEVAT IONS}

The wDHs-8G has beon prevtously likened to a prom jeotlve technlque. In all projective toohnlques, both the rerbal bohavior in response to the preatented otleulus and the sonerri beharior In respone to the total altuation is noted and conaldered to rorleot tho ladridmality of the person tested. sinilariy. In the andrats of the MDis-30 teohalque. both the rexbel bharlor durias the hours of Intensive obeervation and the rosponses to seleeted aspecte of the total altuation are noted and considerve to frotloot the othnie orlgine of the group intolved.

If lndidinale within on group or the other alfrored in tholr reaponte to some atiunlus iten the difference would be Inbeliod an Individual difforenoe and be oleasteded as pohologien. but if the lndividuale whthln one group on mosec differed in tholr responses to a 


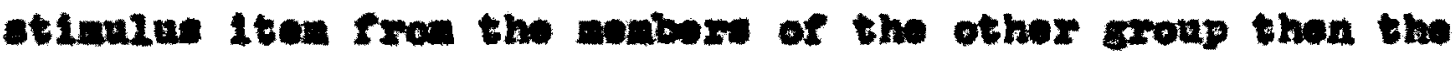

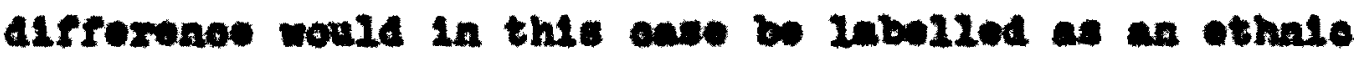

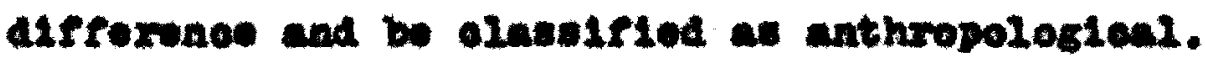

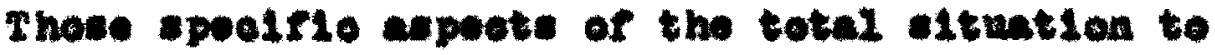

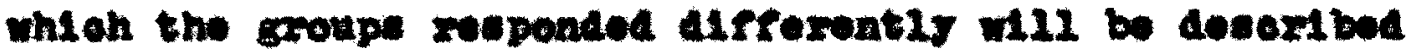

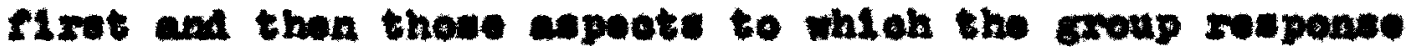
ne the cane w11 bo montioned.

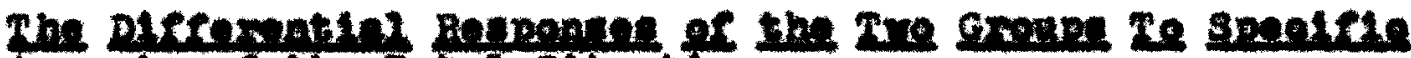

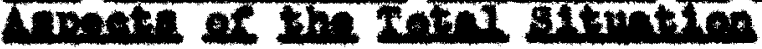

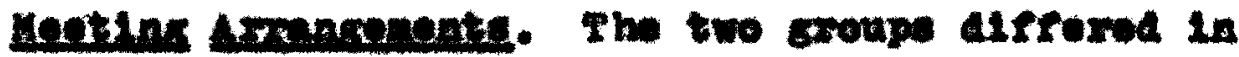

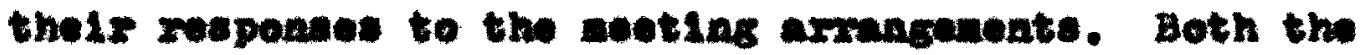

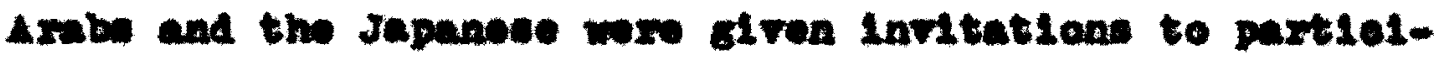
pate in wht wio roprosented to b a croap ith othox

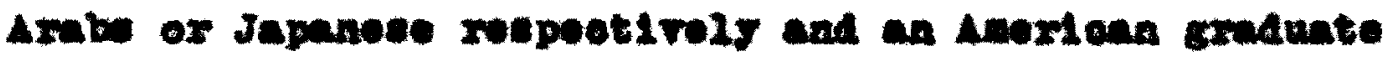

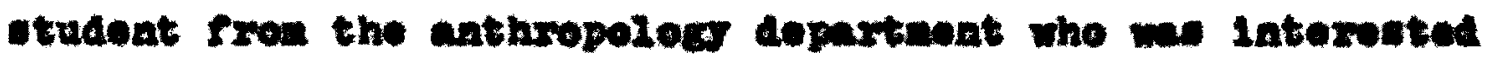

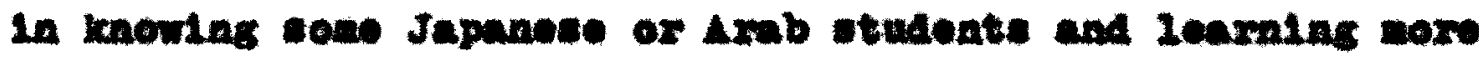
about thetr oounter and ware.

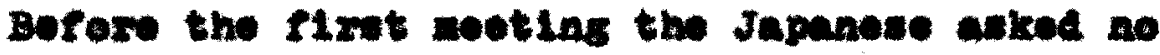

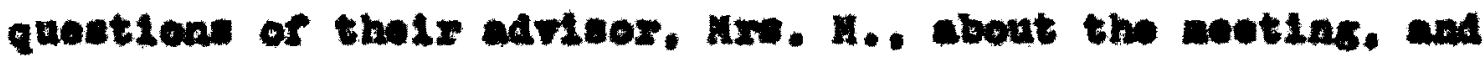

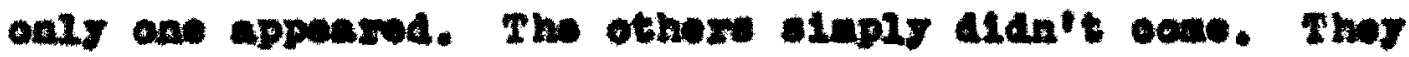

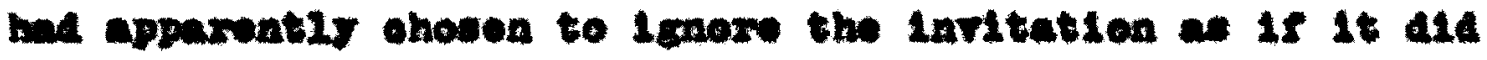

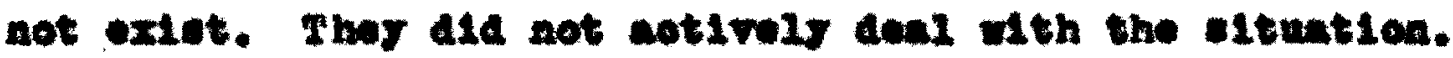

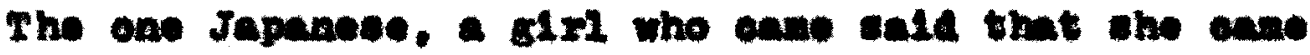

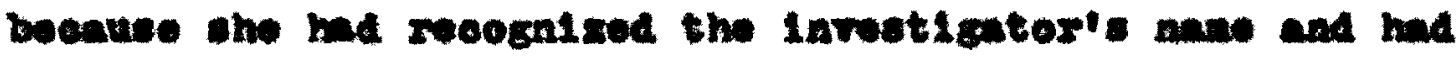

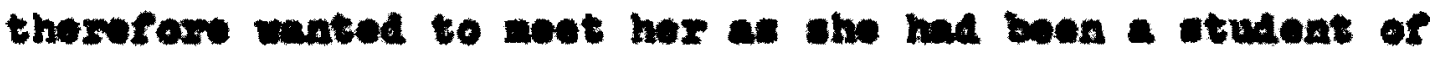

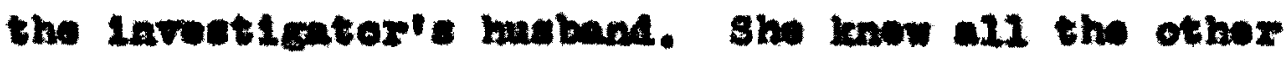


Japanose studeats on the 11ut and went out, called som up and wthin firteon aluntes rour moxe Jepanese otudents had arrived.

On the other hand sone of thi Lrmbe appareaty

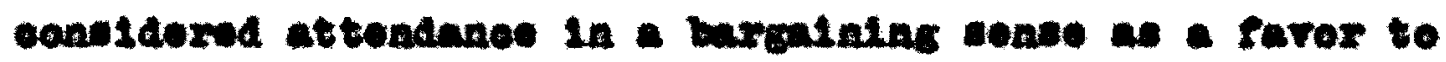
Nr. C.. tholx advieor. He roported that anay of the Axb itudeate had queatiens about the benef1te of attendanee.

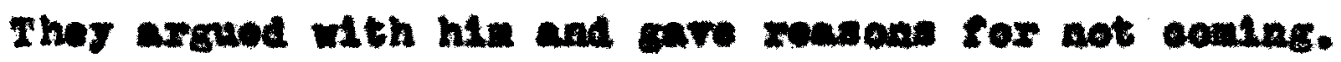
Servexul wexe soported to have ald that thoy would eowe If sothing alse one up or to have ade stetesonte which would aliow then to ohuge tholr alna at the last monent. One

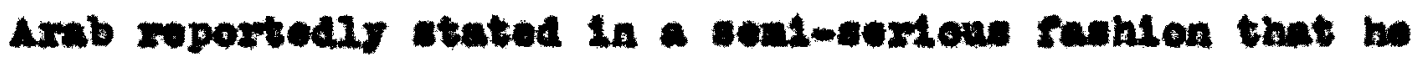

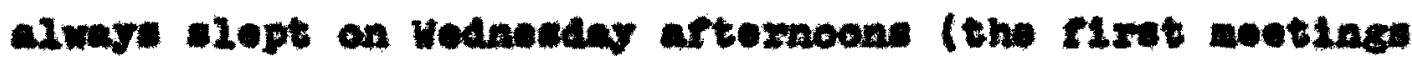
wow on wodnesare).

Desplte the requerte for additional inforation and

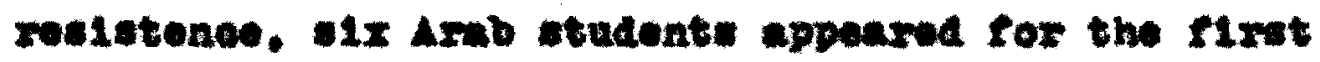
noting.

Tape Beneptex. The resotione of the two croup to the tape weorder wa ent1roly alfrorent. The Japanose pald ne attention to it othar than to nove olocer to the worophone when arked to do so. Cabe. When the andioIsual toohalelan Ieft the roon thor abrod if the croup faolittator wated it onttobed on and thon owtebod it on.

The 4 rabe wated to know who ouned the wohine. what the tapes wers to be thed for and expeolely if thoy wow 
to be paxt of a radio or TV program. San vanted to has thetr roleos after the coseleat. There seoned to be no objection to its wee, but explanations wors roquected.

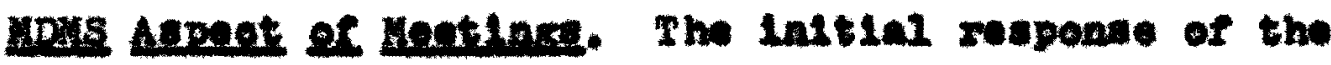
Arbb group as woll as the Japanose croup to the ninimal Almotion alminal atmoture anpot of the omall croup sosulons woro different. The Japanese otudente seonlagiy IIrad the mootinge. Thoy ald not ank quentione about the puxpose of the apeting. That thor could be with tholr

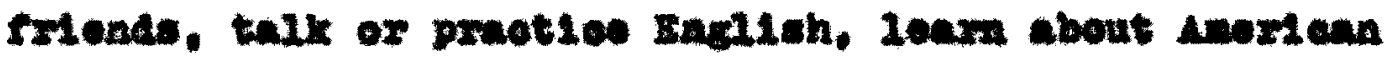

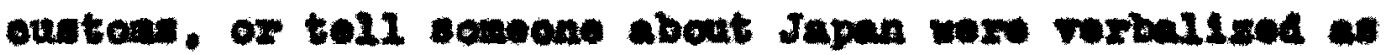
boner1te. Twe montioned that it was a now expertenes for thon to be so frank.

The Arabe on the othor bud arked quostione 21ke.

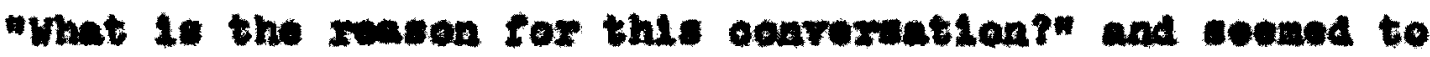
be looking for an unopolen purpose. The flewt Armb cession whe opened by arrage of questions. "What's colng oar" "Ion w1II sak ue some questions" "What's

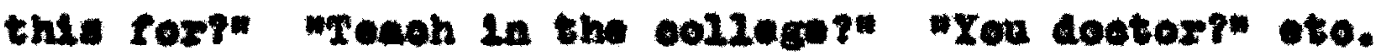
Each dimot quootion wa anowerve, Thoy waxe told aguln that the Inrogtigater wated to not som Armbe and got to

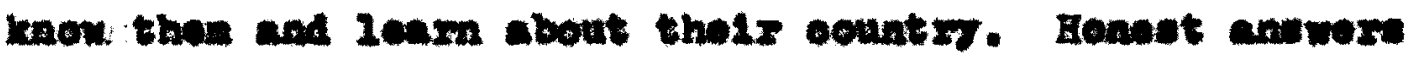
waxe Aron to faotual quontioas. Anowere to thene quonttons soend to male then nor cenfortabie.

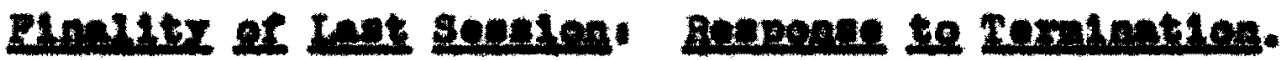

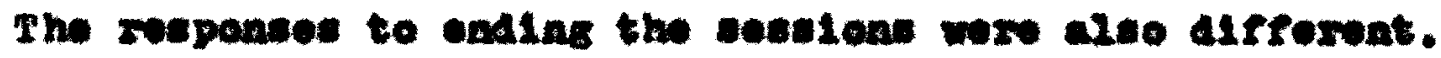


Arter the elxth aecting the Jeganose group deosded that thoy would $11 k$ te centinue actlac on a wooky bels and por-

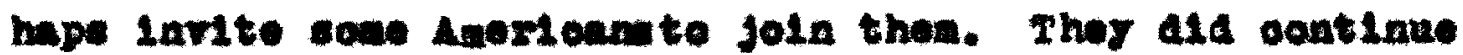
to wout for aix now months.

The Amb sroup's leot neeting wa alnost twied the

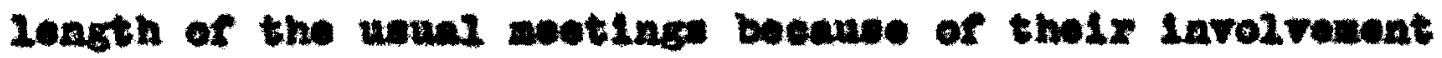
In tho decunsted thoy wore having. bat when thoy onded 1t. thore was no requete for a continution.

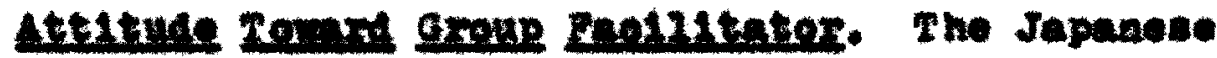
group attitude toward the freliftator wa conolotent. Sho

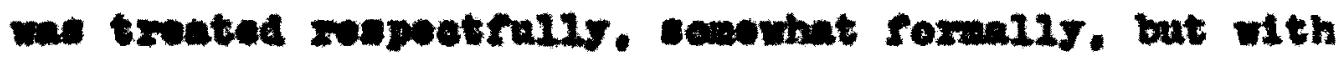
naxmeth.

The Armbe' attitudes temard the sxoup faelistater in thie proseat otudy variod, and those variation orten wexo related to the teple under diecussion. On eaoh oecention whon ane group aomber we alone mth the raoliltator. the

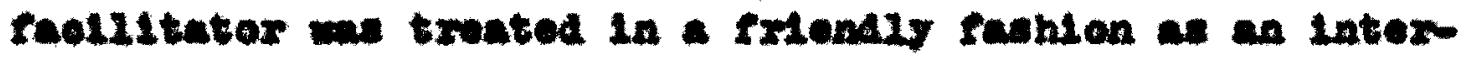
onting Individual of a an indridend who we lnterosted in the Individual exoup nonbor. Hownves. durtas group

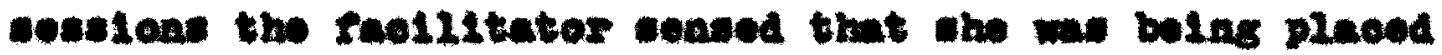
In vargles rolen by the group nonbers. She we once

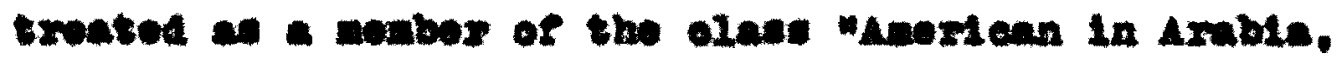

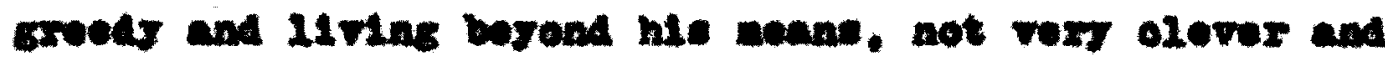
conplatalug" and cace os "a paxwea who nocded oducating

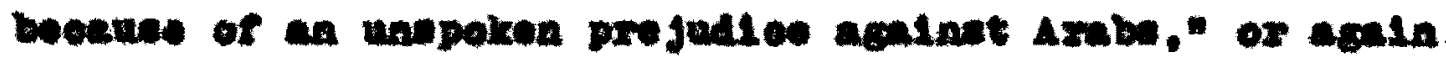
ar "an Englioh tenchor whe we powexleos." One gxoup member 
protended to be a teacher and tried to ari11 the raoliltator on pronunolation. Porhape tho raoliltator mas a "poxeon whose status and potential for anger had to bo ohooked to al at one time or anothar. Sowotines the was "a poxwon who alght underetand tholx problewe and be Influential in thelr solution" or " "poreen whom thor could cell on thalr

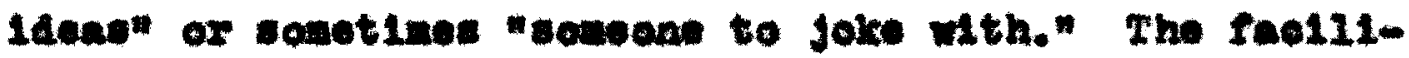
tator alwo wa not reaved to at all at tines while the group weabers Intermeted for long pertode of tine with each other.

Attendenge. The avernge auber of people per seasion In the Armb croup axeseded that of the Japanase expoup. Tho

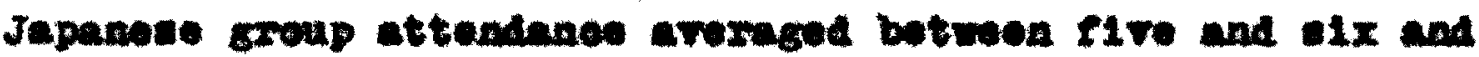

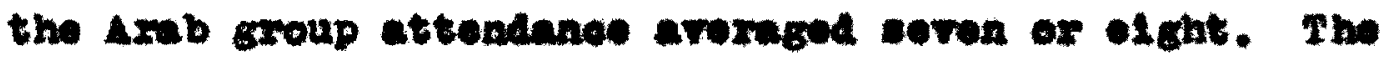
total number of partiolpante in the 1 rwb croup was orer twloe the total for the Japanese group. approximatedy twenty-thwe ceapered wth ton. The abubere aro an approxination beeque the lavestigator did not mat to take

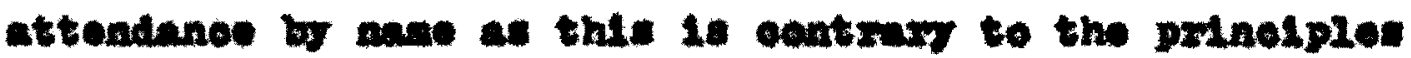

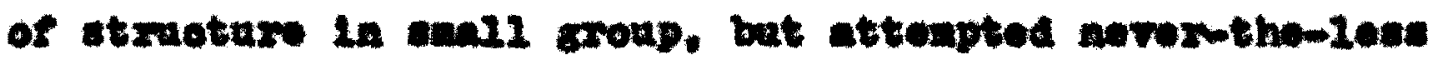
to ronouber taoes and distinguloh botween and note faniliar and now snoup nombers.

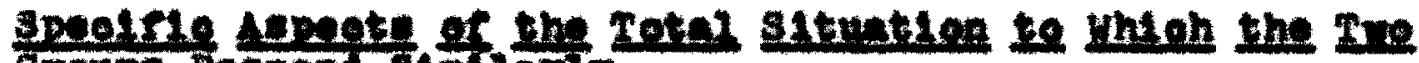

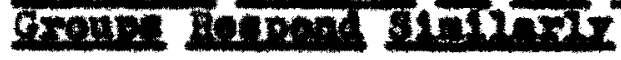

Those wore oaly two epeolfte especte of the total attuation ldentified to which the two creupe sooponded 
Inilarly. These wexe the physloal ooadtion of the roon and the prosenof of the audlom ribual teohntelen. The roetIng plese wal a bullding sohoduled to bo torm down. It war - seall nolsy oluttered ducty roen. The Armba squesed in and 18nored the phyeloal oonditions. The Japanese bohaved In the wame rankion although comotinos they comented about the dift. Mombers from both groupe osendonally sat on papers wioh they pleced on the shalre, but neither gxoup auggeated moring to a aloer moen or oleaning that one.

Both croups ignowe the ande-riavel toohniolen. Bunnax

The two groupe than. seleoted on the bals of difrex-

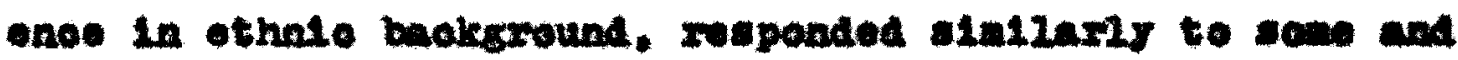
difrexently to other epeotfien held oosutant through so-

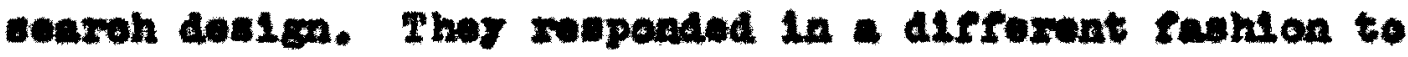

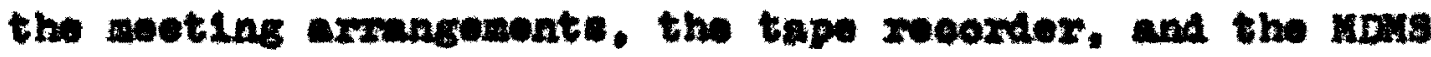
anpeot of the wetinge. Tholr attitudes townd the invontigntor and tomnd a sontinuation of seselons difforva alle atteadune partioniars. The two sroups rosponded eldilariy to the phriteal conditien of the roed and the

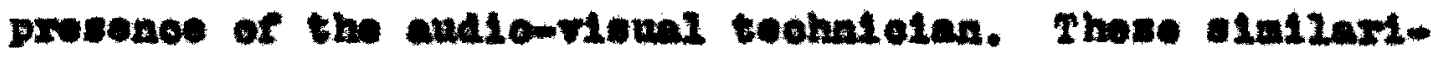

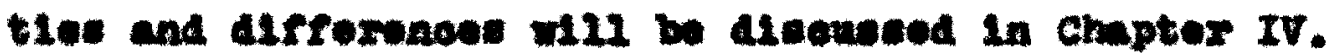
An we previously wontloned. a considerntion of the orgentation wthin the Armb group and Athln the Jepanane 6roup w12 be doueribad noxt. 


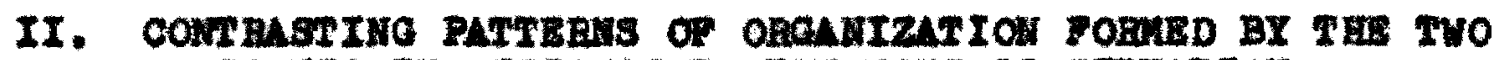

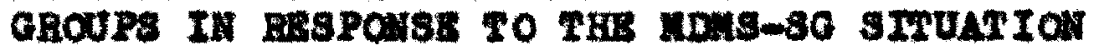

The Affementivi weponses of the two expape to Ident1flable otimull, 1.e. the row, the tepe reoerdex, ote.. have boen alsounced in tho proviow seotion. Tho patterns of organization, however, esanot be sarrowed down

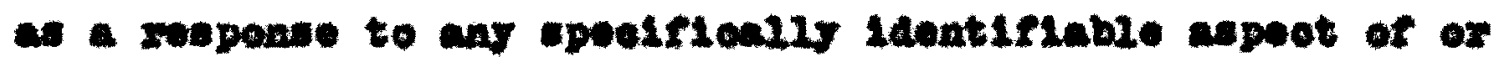
stinuins Mthin the MDHS-36 stuation. Sueh pattoras howorer ax obaervable onl undor coudtitions of liatted Arvetion and IInfted atrueture on the part of the anthrom pologlst whathor ho 10 working in the rield or in a nous-30 stuntion.

Liniting both diseotion and otrueturing on the part

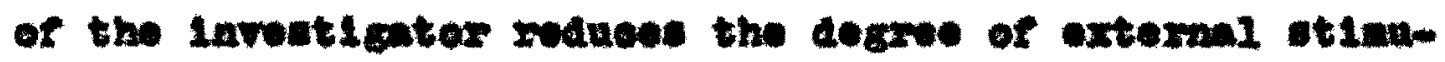
1at1en. Al the degres of dimetion and atmeturing appromohos sero. the etimul poouliar to and provided by group radiltator approsehou zero. If the Lnvestigntor 1eade and struotugen a group attuntion, ho is providing

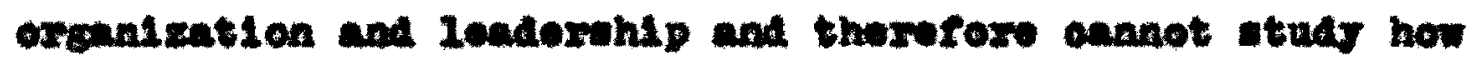

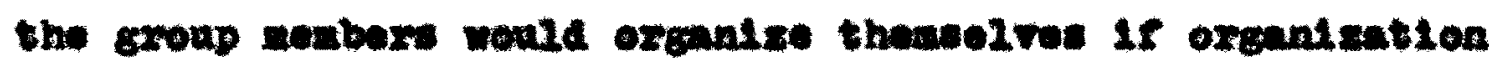
wore not provided or spolied out, beenes the oreanlestion Inposed oy the Investientor would ston trou tho oulture of the Inventigater.

By Lintide otzroture la a group, the group faoli1tator an obeorve how the group monbers oxgendse thomedres

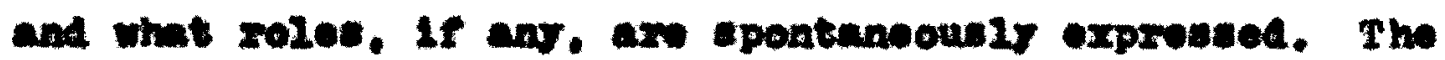




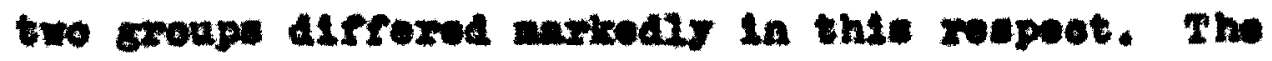
Japanose group r120t and thon the Amb group w11 be deseribea.

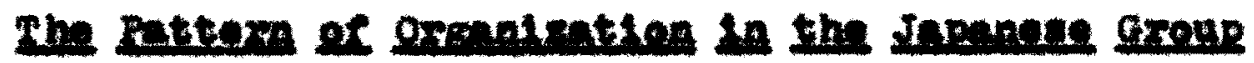

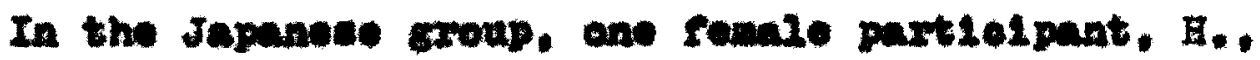
asted as combetween or Ilain roprosentative between the croup and the group raollitator. She alled or perwonally contagted tho othore and molnded thom to somo and sowe-

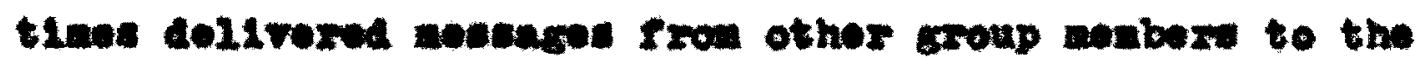
radiltater. Whon tho sroup faeliltator attampted to con-

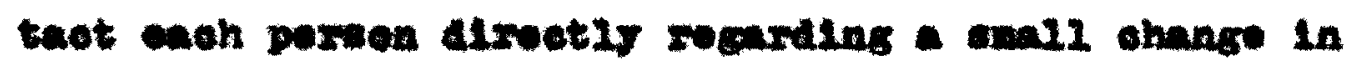

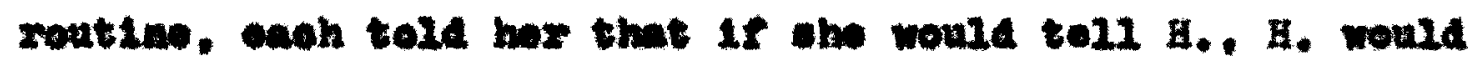

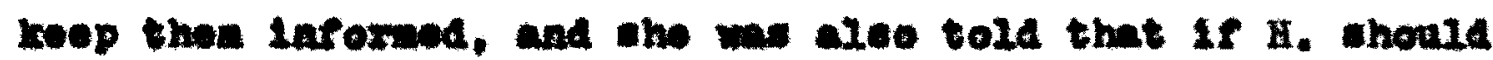

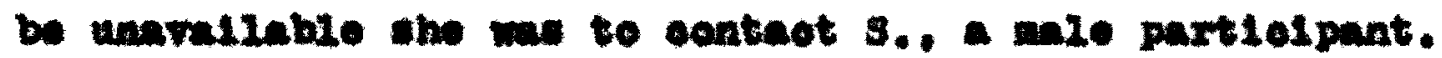
(H. had been If the Ualted states leager than ane of the othore. She wa knom to be efrialent and rollable and the

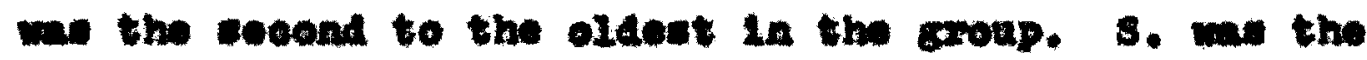
oldost. He had been in the United states only a fow sonthe

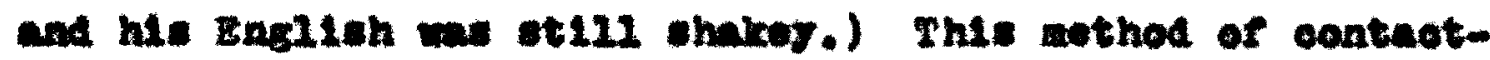
Ins the exoup and miating moesages almape worted. Note the dingun in regure 1.

H. orten apoke for the group with the groupl: concent. Onoe the fool21tator asked a quetion about Japan of throe

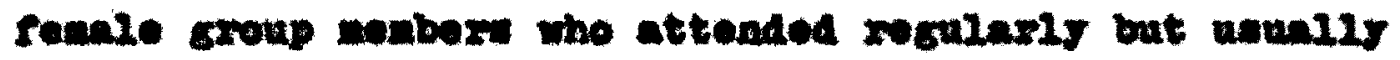
opoks only mon spokst to. One annwerved by ouring that if 
Japanese

Llevon Eoprocentertive

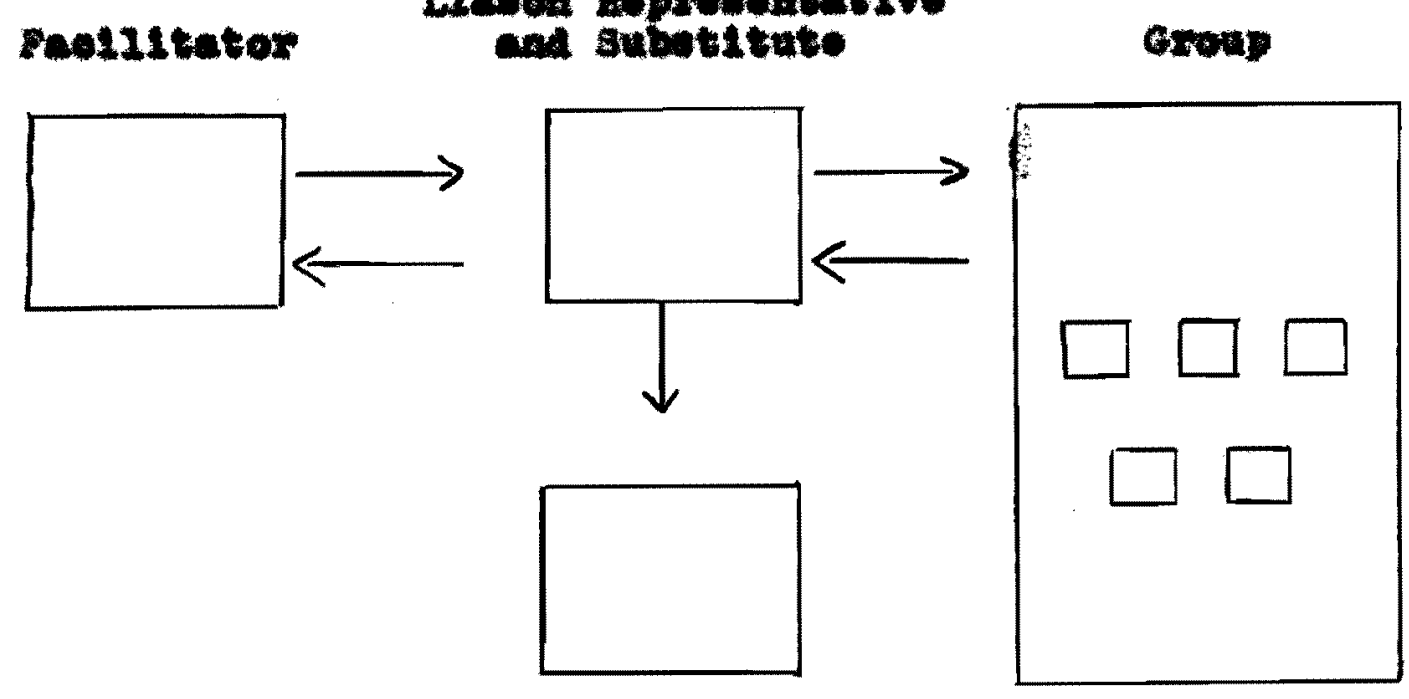

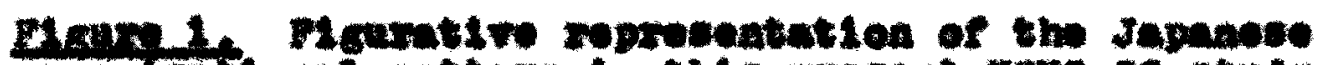

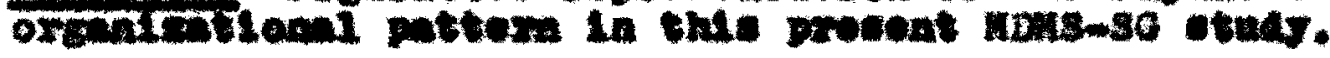

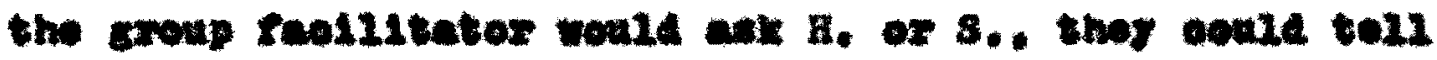

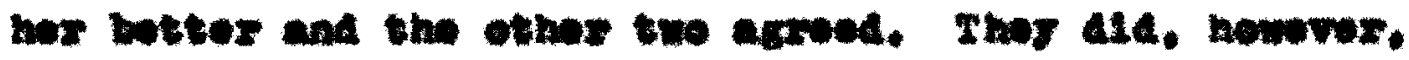

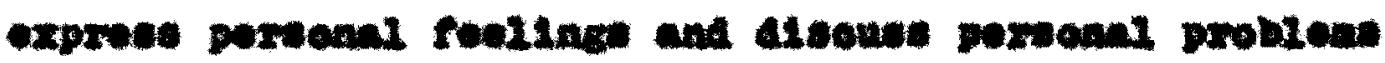
thoy had.

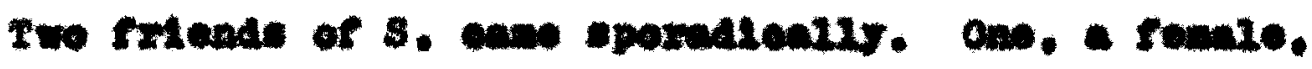

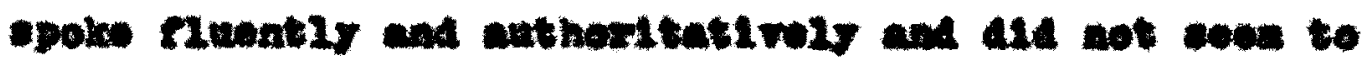

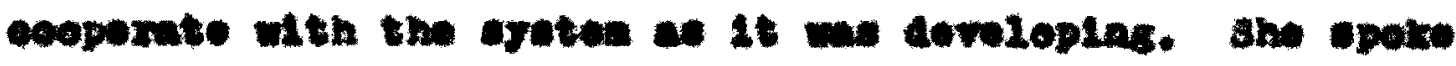

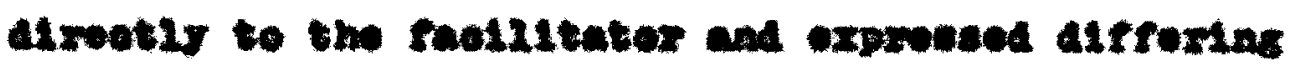
optaten and ow Infornatson then on cume. The other

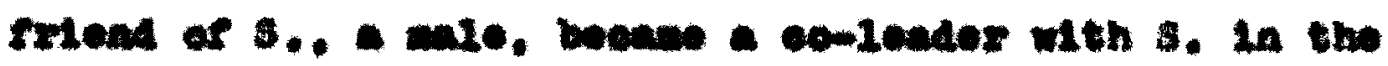

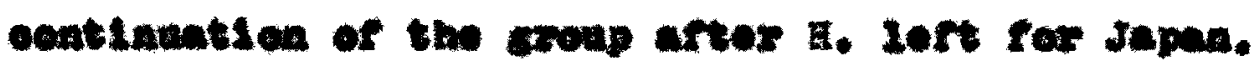

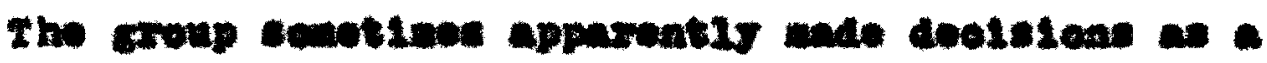

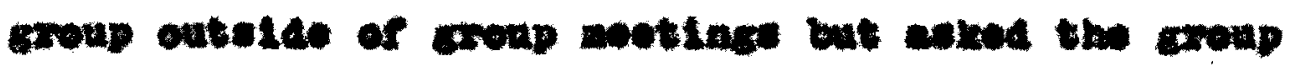

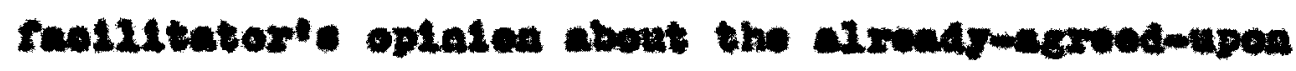


deoleton durlag the aeting. The deolelon to continue the

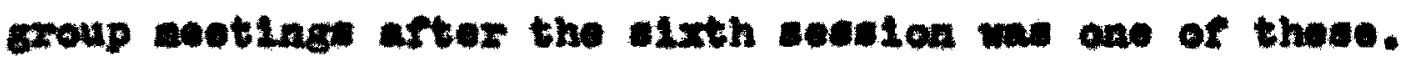
Anothor wa a desialon to not hare a eoting duxing a test woek, and the thind we about havins a eviclyakl party.

The Pattere of oxmatration uned in the Amb Grop.

The Axab group'a exganizational pottexse were on-

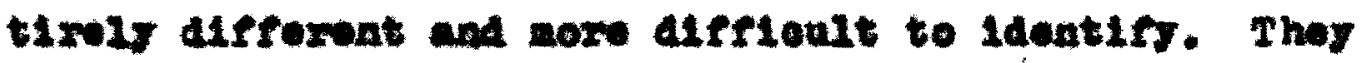
asked the group facllititer to work through Mr. C.. thalr edvieor. "who know than all," This proved orflolent alnow the turnover of andership we groster than that of the Jepanges group.

Durling the seselone, howrex, Mx. C. partletpated

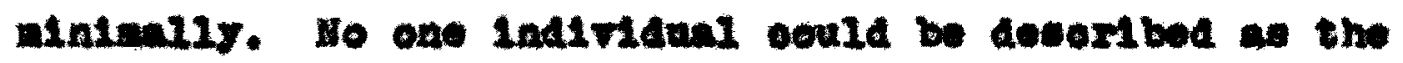

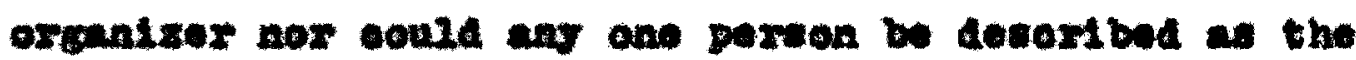

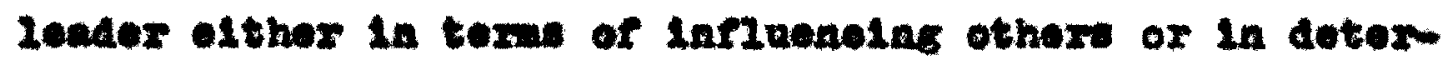
aning topios for disoundion. Tho eldewt of the joung mon, when he attended, talked mors than anjone olse, he had been in the United states loagest and had good cownand of Englimh bat he did not wean to load the otherw. In enoh sosalon at least two Armbe, and in one seasion five Armbe,

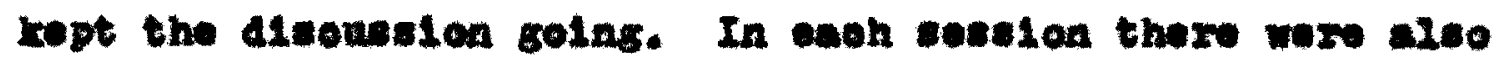
almare soe qulet onos. Tho partielpante in group A-1 wex.. an the aroxage, rounger. al judged by eppeaxnoe than those

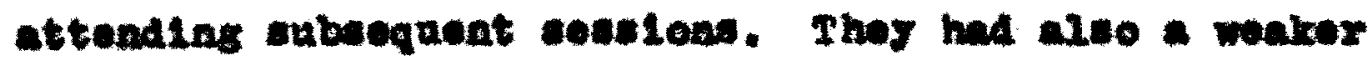
comand of Eagileh. However, the two Individualn who woxo 
nost rerbal durleg aosalon A-1 wex not verbal duriag

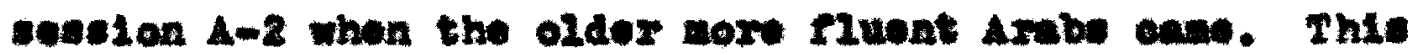
ooourred dosplte tho ract that the older Axnbe wore guoste zather than having been oxtginally invited by the gxoup racli1tator.

The talkat2 a postion on save wbject and then wah would defond he position or argue the mexte of me oplatons. They tended

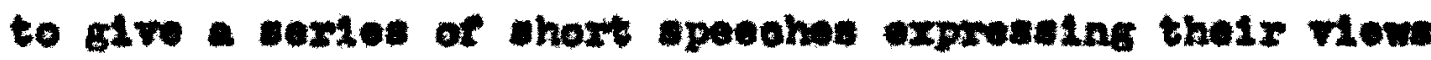

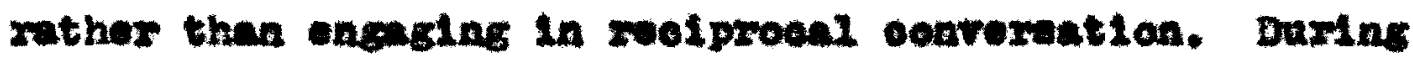
overy aesalen Individuals competed to expreas thelr riews. No one soeved partieviariy InRinoned by those speches. generally, although oseasionily the spenker would medify hie oplnion to lnelude anothar polnt of rier. orten otherw ald not rowot at all. Onee a joung an allontly roud a nowepaper and no ane noomed to notion it.

One roung wan whe had raxy roeatily oene to the United states attended rogularly. He almare soomed to be oware of what wa bolng eald and although ho did not epock orton, whon he ald, ho we Ilntened to. Ho seenod to sum up problem or act a arbitrator. Ho brought wor frionde to the group then unrono alea asd. Onos ho told the group that the faollitator wated thon to talk as they would in

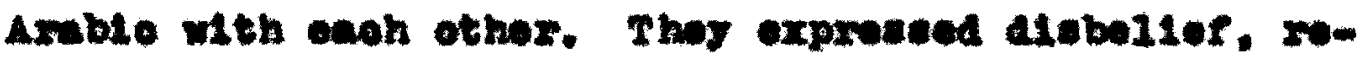

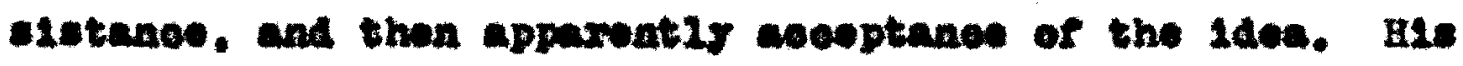
rolse we quitet and conotines he apole only a fow sontonoce 
In a hour. He wa the only quiet one to Inrluonee the

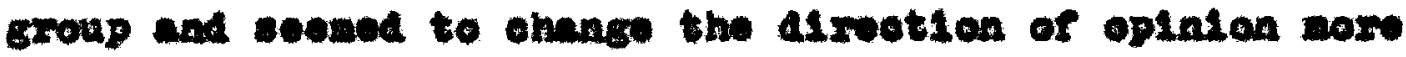
than thoes whe 2eotured. Ho we, however, not eoweldered

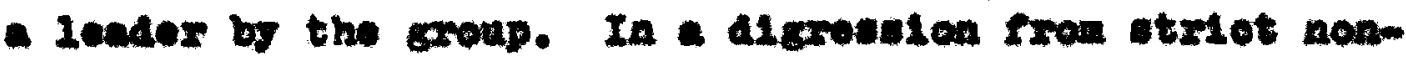

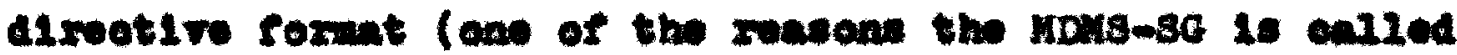

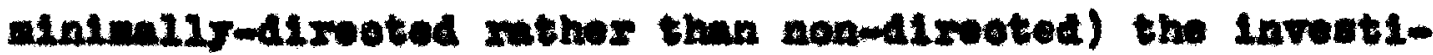
gater anked the group whe ther conalioxed the zeader or 10adors of the croup. The nombers of the group renteted laontifying anjone of the group an a londex.

F1 gure 2 engente the $A$ mb oreanientional pattern anouned in tholr noMs $-8 G$.

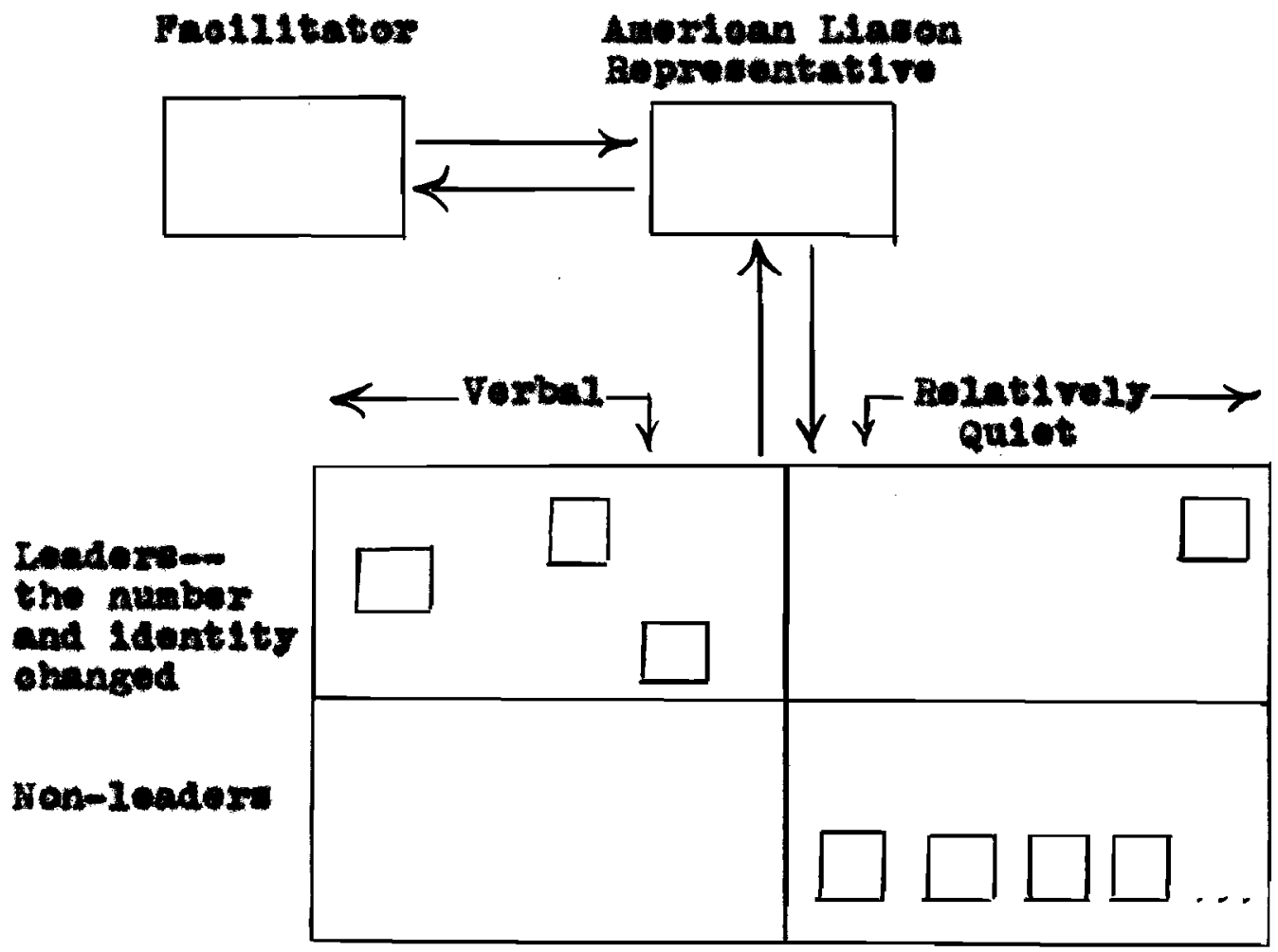

Ploum 2. Figurnt1 re reprenentation of Arab orearrational pattern in this present kDis-sG studs. 
Different poople ane to elfforvat motinge, but aorer-tho-10es those seenod to be a thread of continulty throughout the cextes. The inventigater after seaston ones acked twe rouns won whothor or not thoy talked anons thoseolves abont the acotinge. thinklas this alght have contributed to the continutity and one eald thoy did, and the other sald thor ald not. The aubjeot we nover dieounsed at a noting. but the asevaption we ande that there

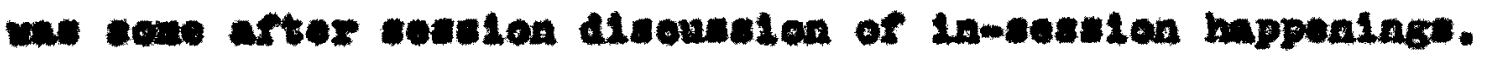

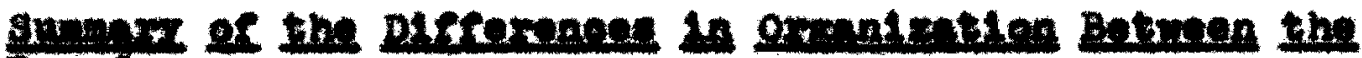
The arata

It w11 be noted that the organlextional patterna or the two Group alffornd radienily. Thoy wore allke oaly In that thor both donicnated an Individual to aot af Ilasen represeatative. The Japanase, hemever, used Japanese

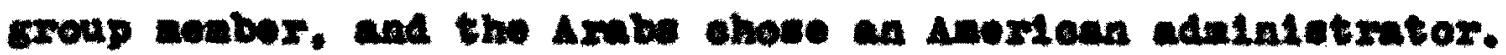

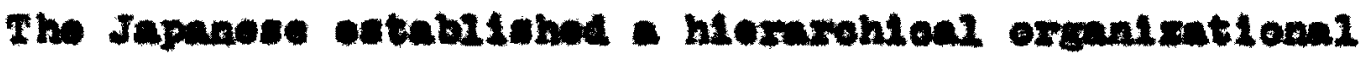
patters whioh Invelved only on dineonting nomber. The Armbe difled thomelves Into thowe who sonpoted and those who did not and thon those who coupoted, compoted

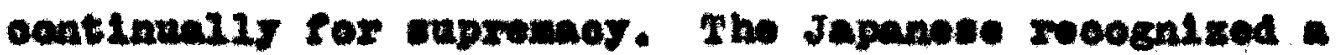
Ionder and the Armbe meruead to rooogntse a Leader and exprosed beller in froedon to think and aot Individunily. The anxt paxt of the data soetion enocapaeses the oberrmthen: and andrele of the rorbel batwortor of the two croup. 


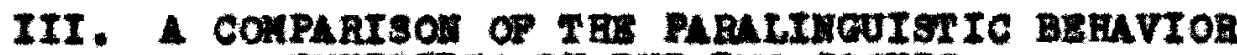
BXHIBITBD BY THB TWO GROOPS

Whon the data fren the Axwb group wa eonpared with the date from the Japanose sroup. It besene obvlous that

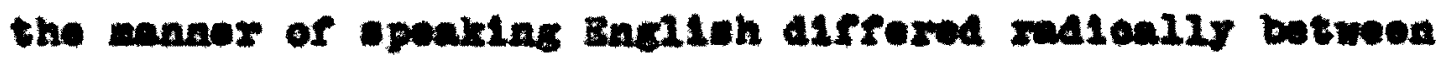

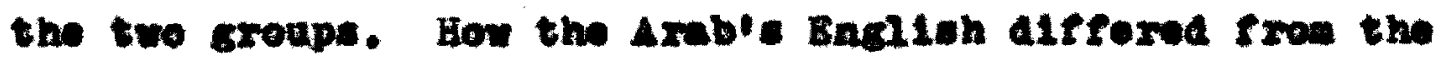
Englioh of the Japanone we not roadily appareat, but by I1etenlng to enallor and oneller eognonte and by conparing

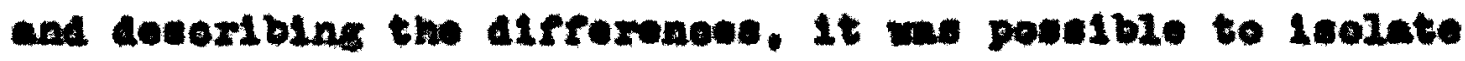
the facete of alffervnoe. The leolated racets of differones wore then oheoked on cach tape throughout tho oorpus ror coneletenoy. (Granatieal and phonologleal alfreronoes wero expeoted, noted and dinxegarded an Irrolevant to the parposes of the present atudy as this is not a oleveleal atudy in linguiation). The obaerved and dosoribed Ilngulet10 phonomene antioned bove rall under the rabrio paraliagulaties. Parallagulatios to dorinod by Narto Pel

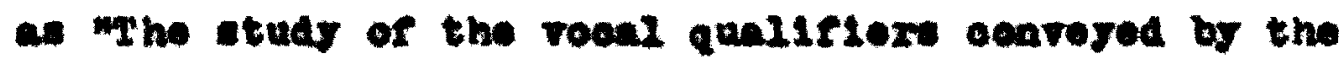
veles, but not through worte of pltoh 1ovel or intonation. - (1966193) Tho torm in wed allghtiy alfrerently by alfforont obholary, bat it wil be uned hom to xurex to what 10 lert of apeech whon ane 1 gnowes both the etriet kinesios or bedy Iangrage and the part of language whioh 10 etruetured. 1.e. phoneave, Inolnding aupereogmentel phononos, morphones apd eratex. Inoluded $\mathbf{1 1 1}$ bo the wy one opeake, the rolued. plton (not ineludiag pitoh 
phonoses). tompo, Iength of utternnoe and response to allenees between utteranoes.

A prolininary paralinguiotio analjals of certaln asposts of the Arab and Japanose group date wa made. It was of partlouler intervet beouse most of the nenbers of both Groupe had taken the wane epoken English ooureos at Portinad state Univeralty. We wight Infer therefore that

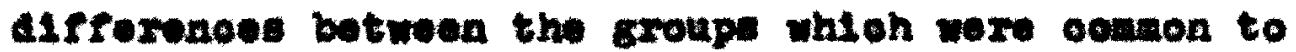
members of one sxoup or the othar would be oulturaly derlved rather than a funotion of the wa they learned to epeak English.

Curetul andrale of the two exoups showed that the Amb sroup on the whole epoke wore louly than the

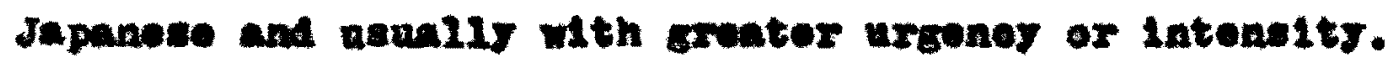

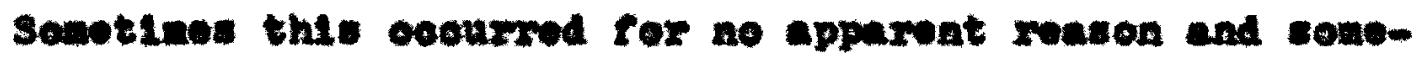

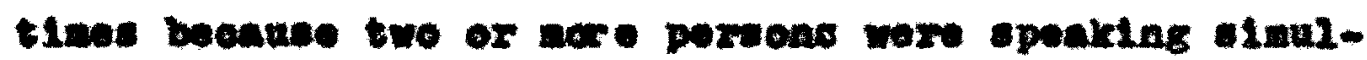

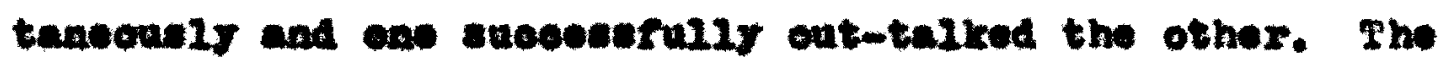
Japanese almout almye opoke one at time and with lene

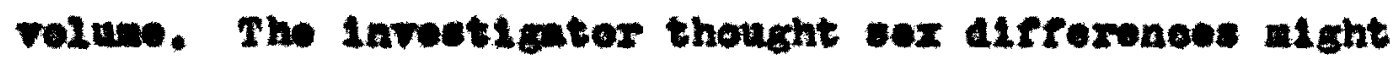
ecoount for the Alffowono betwen the groupe, that is that wan wight bo expeoted to talk wox loudy than wosen. Howerex, a reaheok of the enterlale proved that this 1 dee wa lnoowret. That Japanese whoh wa epoken loudy and Latentely (1t oocurrod on two tapes) was spoken by two

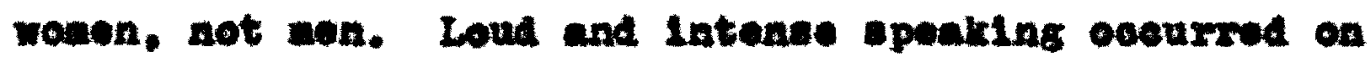
orery Amb tape although a fov Individnal Araba spoko 
costr.

The Intonation range for the group we rreater and aors rarlable for the $\Delta x \mathrm{~b}$ group than that of the Japanose.

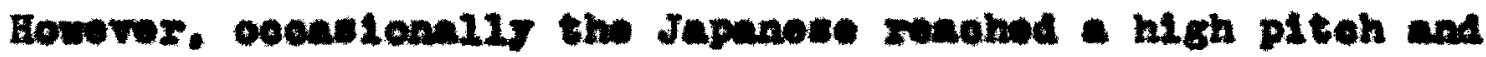

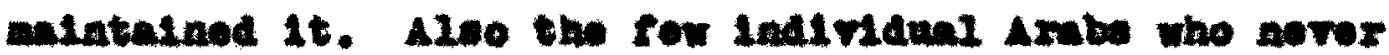
Inleed thalr voloes notleombly in rolun alto ald not notleably rary tholr piton.

The Axwb had a Mgher woxte por alute rate than the

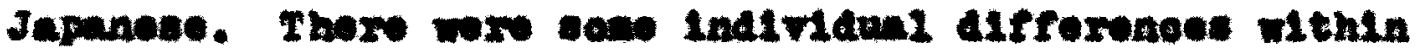

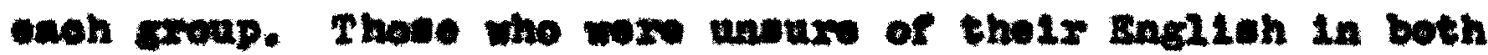

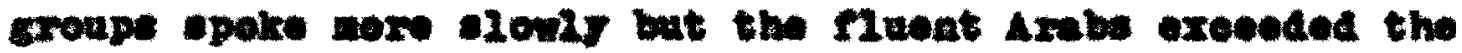
Iluont Japanese in speed of epeoch.

The two Groupe alfrowe warkody in the avorags longth of attermace. The Amb exonp nonbers often coatlanod to

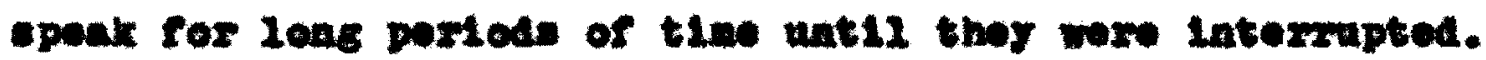

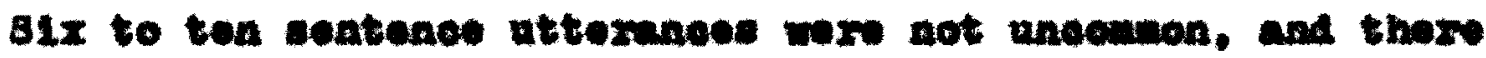
wore ceme uttermase twatr-f1 re sentences lons. Ine Japa-

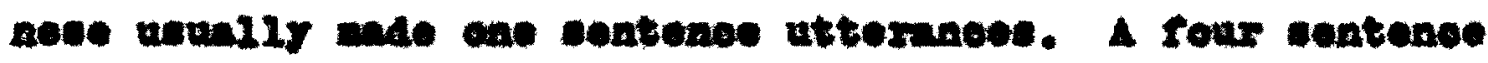
uttorwnes wasured.

The leagth of tine oedurxing botween uttornaces

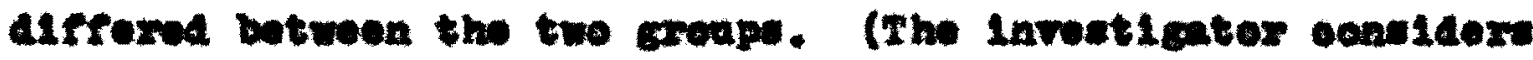
the obserwation of allenes te be part of the paralingulet10 obervations.) It we noted that both the frequeney of. and tho duration of ellonee wa creater is the Japanose eroup than in the Arab group. The Arwb rilled spaes of tine duxting whioh rerbalization wa not oevuxing vith elearing 
thelf threats, and Ith Ianghe or nof nes fran sovenonts of ohalrs. ote. On the Japanese tapos openslonally a ellenee

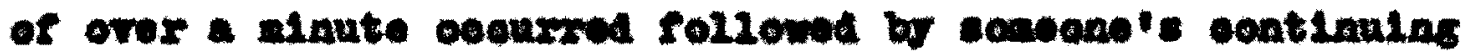
- converation or atarting a now tople as If no slience had oocurred.

One Axb froquentiy repeated purt: of hie seatenos, 1.8. No. no, no, I'n not caring, tho thing - tho thing the thing. I'n not arring the is the - this the - this is

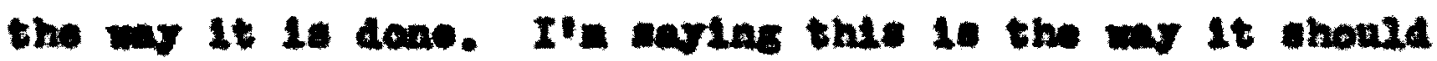
be dene." severw othore in the Amb group ald almilarly

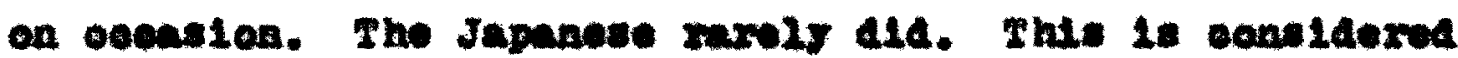
by the Investigntor to be an Indiriduel phonomon. Thow wat so opportinity to see whother or not thla Amb ropeatiod parte of seatonoos in Axnblo.

\section{Sinmax:}

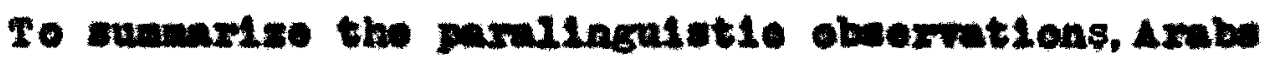

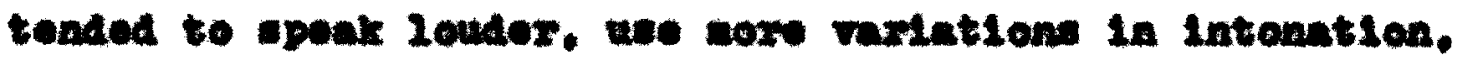
tall fortor and for loagor porled of tine and arold periede of elloned noxe than the jepanese. The Japanese spoke at a lower teapo wth lous rolume and latonation veriation. Thoy used shorter uttermese and tended to coept ellenoe st a naturul part of eponking. The appot. paralinguletios, Is an inoluelve antegery nane for the obourved apolifios which diffored

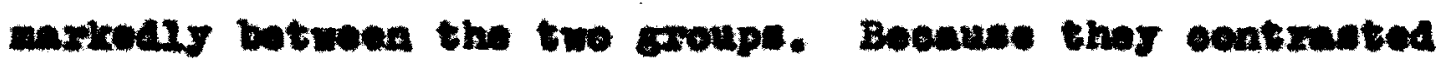


oharply and wexe group phoaowond rather than stagle

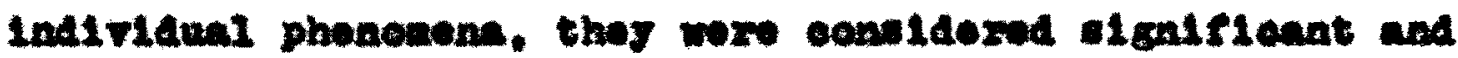
thoxprox poeslble zerlection of the two larger othale population frow mich the owaller group wex selooted.

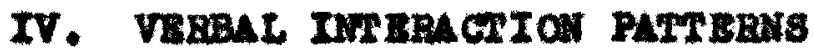

Prelintary obeomations of the $A x b$ broup and the Japaneas sroup ade it apparont that the Individuale wthIn eagh exoup treated wah other differently. 2.e. tholr Intersetion pattoras afterva.

41 pooplo ween to exhlbt oorteln intermotion patterw. In all oultuses information, optalens and/or sugsontlone axe exohanged. Also, provunably, antegonlen and olowenese, ote. ar verbally axpreased. Yot thore coes

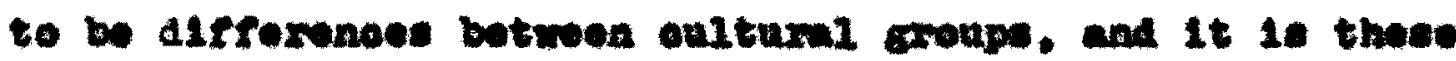
Alfforenees whtoh are cxantand hax.

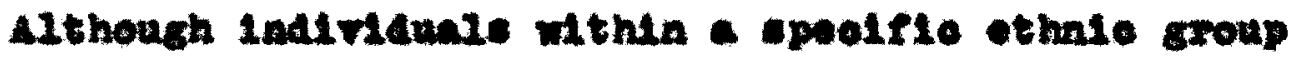

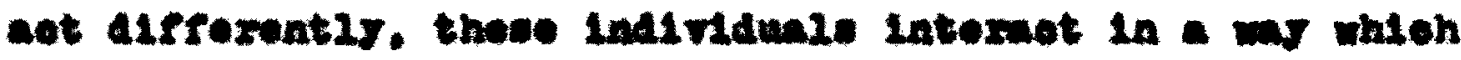

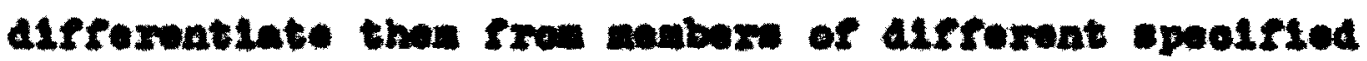
othate expupe and, es wth dialeots of Inngueges, the dogree of rolntednows botween thale sroupe could be teated.

It 20 alee expested that in difrorent extuatlons Arromet trpes of Intermotion axe wed in rerying degrees. and aro connldexed by a people to be appropritate to - Exover or Iovanr degroe. 
If wonbers from cach of twe othnis group are ctron a

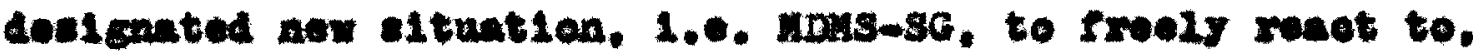
the laternotion pattora thor oxhible and the total pattera of reaction exhibited. 1.6. A comparison of the rrequeney of the types of Intoractions involved, should tell we lot abent the internetion patterne of the iarger othale unite roprosented of the anall croupe in the provent atudy.

The Intoraetion paterna ware andraed in two steps. the one otep uppleantine the other. Fixt. the trpes of

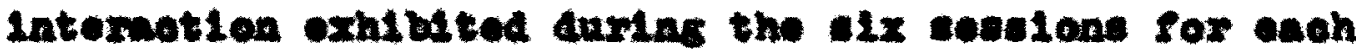

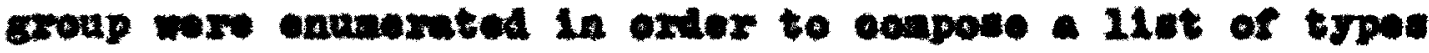
of Intermotloas and then a presenosmbeneno count wa mede In ordor to charwoterixe and contrevt tho two groups. Thon those Itoas whioh oocurred in both croups wers sated as to froquenoy of ooourrones.

It should be nentionod that there id affioulty inrolved in diatinguluhtas exprenelen of exotion and inter-

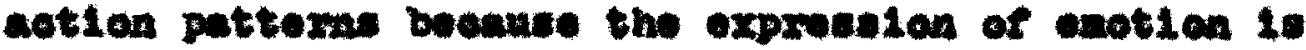
conotino the inftiation of an Intermotion, conotinos tho roault and aonotinos a conocidtant abpot of a total ovent and not rolated to the propess of latexuetion. Wha a total oront is analyaed into constituont parts. Its

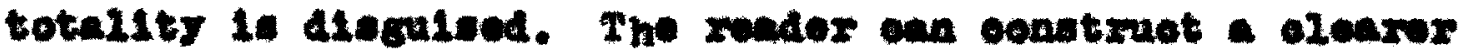
ploture of each group and of the cantmet botween these two croupe arter be has sead tho entixe study involving the

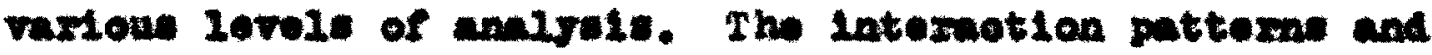


the andyele of enotion whloh follow, of. seotion ontitled

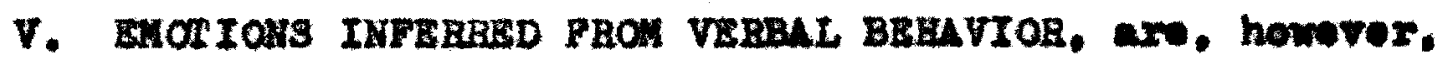
olosely selated.

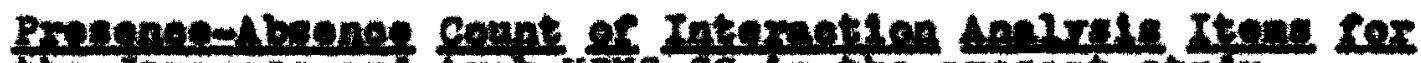

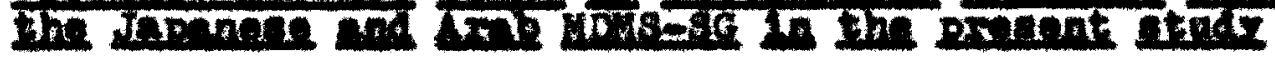

The fixet 1toms to be 11ated w11 be those exhibited only by the Japanese in the Jepanese Momb-SG.

1. Toasing and joking Ileltod to Intormotion betwean wales and fenalos. Intiated by elther.

2. Apologites made for having a drforont oplnion.

3. Attompt at egrement on some lerel indtiated

after each expreasion of Alfrexting oplnion.

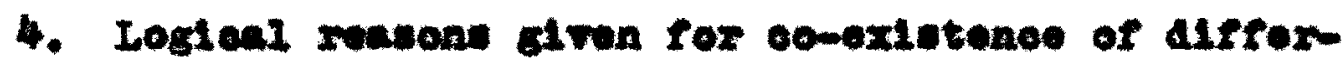
ing Laeas.

5. Rospot and atatue siven to faoli1tator and Ileson repreacentative.

6. Pear of group xojeotion exhibited.

7. Vortal expreselion of worry and constelvity to other'a rwatlone mat.

8. Lonolineus verbalised.

9. Dosim for hurmonlou relationshlpe rerbelised.

10. "Ban han" sounds as if to enoournge enother poxwen to contlane to rexbellso to aseurs hin of the Inttlator's presenoe prodnoed.

The ltow whoh follow are those itow oxhiblted only by the Axbe in the Amb KDMS-8G and not by the Japanese. 
1. Compotition.

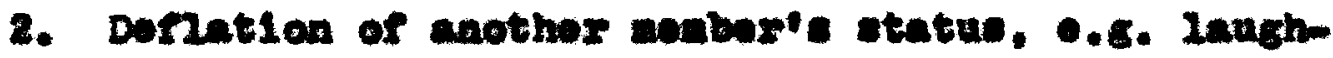
Ing at anothar'a anbarrusenont.

3. Contrualotion of other exoup menber without sotieenoe.

4. 8elf-esentive bonatior.

5. Uee of expletives.

6. Jes of domand forme of contenees.

7. Prosontation of Alfrortus information or oplnion with no attenpt to roveh eroup acroenent.

8. Controatatien.

9. Defonse of pectiton with foot and $10 \mathrm{gle}$.

10. Persuantoa.

11. Joklng and tearlug botweon both malo-fonale and enlomale.

12. Stating demand in the abotrmot.

13. Angwerting "now to "olthor or questions bofore aneworing thou.

14. Vorbalizing cosine to arold talktas about a apearle tople.

15. Exproveion of zegret.

16. Questioning to elarifs intent of otherr.

17. Exprosesion of having bean naralziz treated.

It 1s olear fron the above two llete that the range of Intermotion patteras oxhibited wa grouter for the Armbe than for the Japanese. It wa aleo olear that the 
Interaotion patterne for the two gropp alfror radiedily.

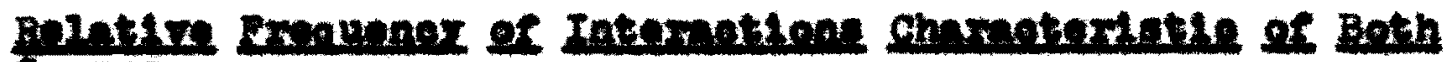
Crange

It Is readily soen that ourtaln itom oocurxed only In the Japanese croup and othore appeaxud only in the Axab croups. A thind list wa cenplied of ltons whioh ooourred with both groupd. In oxder to desexibe the ohnrwoter of the sroup nore socurately. those itend oocurring in both groups woxe rated by the lavout1gator on a rating seale

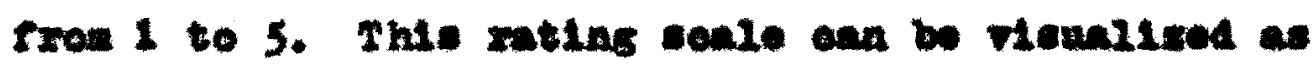
rollow:

\begin{tabular}{|c|c|c|c|c|}
\hline $\mathbf{J}$ & & $A-J$ & & $\mathbf{A}$ \\
\hline 1 & 2 & $\begin{array}{l}3 \\
\text { ex }\end{array}$ & 4 & 5 \\
\hline 31 & J2 & $\mathbf{A} \mathbf{J}$ & $\Delta 4$ & 45 \\
\hline
\end{tabular}

4 rating of J3 indleated that the Armbe and Japanose in tho prowont study could not be dirrorontiated the ono frow the other in reapert to the Itea wth the J3A rating. A

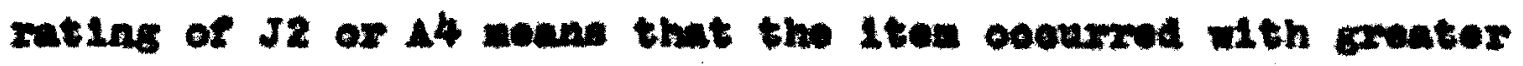
rroquenoy in the Japanous or Axab croup sonpestively bat not orten enough to bo alearly difrorontiating. A rating of $\mathrm{N}$ Indieated that in the prosent study this iten oceurred 
nowe than twice as often anong the Japanose an it copurred

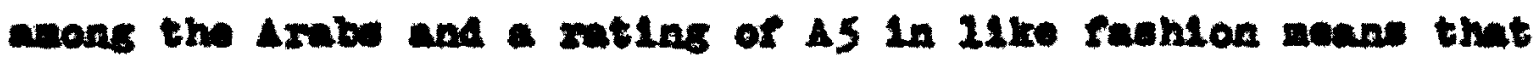

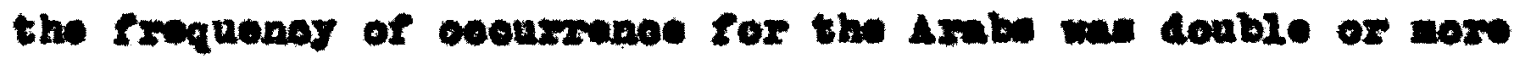
than that for tho Japanese croupe. Thus the It and 45 stem can be conulderod a dirferontiating.

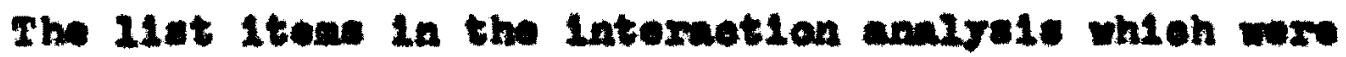
cenen to both groupe followe. The 1tone are 11sted, and whon noeseany for olardty. explatined.

Plxat those itowe wioh did not alfrementiate ane Exoup from the other. all reoeiving a mitas of J3, w11 bo equeorated.

Both Groape!

1. Bxpronend 14 res and proferwaen.

2. Bxproseced dostres.

3. Panoed judgente, nocetive and posttive, 1.e. expronsed approval or disapproval.

4. Showed exbarrmasuent by hositating and glecilng.

5. Gave infoxmation.

6. Bxprovered opintons.

7. Bxprosed postive motsen.

8. Apologized for the quality of thelr Eaglioh.

9. Oeoaslonalis Iapaed late thelr om languages.

10. Alked for help ance.

Tho $\mathrm{J} 2$ and 44 1towe 111 be 11 atod noxt. beginning with J2. The Japanose, wore thas the Axabs. 
1. Hequested opinions of others (rare in both groups and usually direoted to the investigator).

2. Fequested information, 1noluding. "What did he say ?"

3. Made apologies.

4. Gave greet1ngs.

5. Reminisood.

6. Told of achierements of family nembers.

The 44 118t of 1nteraction 1tems follows. The Arabe, more than the Japanese,

1. Gave orit101sm.

2. Offered augsestions (rare).

3. Attempted to discover the raoliltator's wants.

4. Expressed disl1kes.

Further study wth a different oorpus w111 be necessaxy to determine whether or not the J2 and 44 1tems should be olassifled as difforentiating or not.

Finally the J1 and As 1ters w11l be 11ated. The J1 1tems, wh1le ocourring in both groups ooourred with over twice as muoh frequenoy in the Japanese group as in the Arab group.

The Japanose, more than tulce of often as the Arabs,

1. Told of acoompliahmonts of other members of the group.

2. Attempted roonolliation following any contradiotion. 
3. Asroed.

4. cellaborated.

5. Telked for somene alve.

6. Spontaneounly introdued frlende or self to reodiltator.

The Axwbe, wore than twles as orten al the Japanose, 1. Repented thouselves apparently for the purpose of

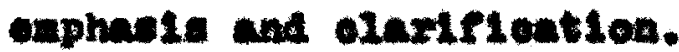

2. Interrupted anothor monber's opeoch.

3. Wade epesohes or tolllogulzed.

4. Ianghed at joke: and homorous situation.

5. Provdly boated of aohlewononte, progress and hanttage of thols conatry.

6. Exproesod Alueatiarwotion.

7. Bxprosed Intensity and exoltesent.

8. Disagreat.

Thewe lavt two 11ate. II and A5, along with the flret

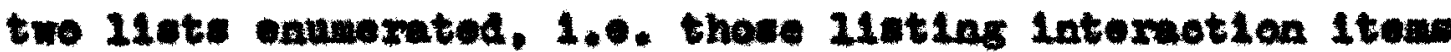
oxhlbtted only by Axwb and onl by Jepanese en togethax be conidexed to oharatexize the contrusting and thorerore

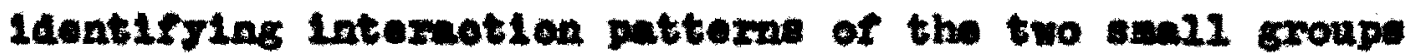
under atudr.

It is surprieing that the number of difforent interetion patterns exhibited by the two groupe individunily exeecde the number axhibited by both gxoup in conson. However, it 1e possible that Intermetion amalyele of group 
from varlove oultures would provide indight: into those opolifle acte in intexpersonal relationahipe that poople from alfrexting background find unoontortable or alfeloult. rot eannot quite put thelr ringer on.

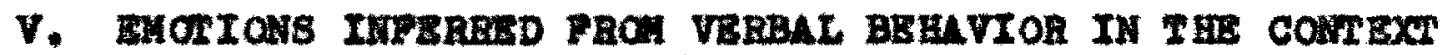
OF THE TOAAL BEHAVIORAL sTrUATION

In the wotion ent1t104 IV. VERBL ImERACrION PATrEars the aloes relationohip botwen the study of oxprosulon of onotlon and Intermotion patterns was contioned.

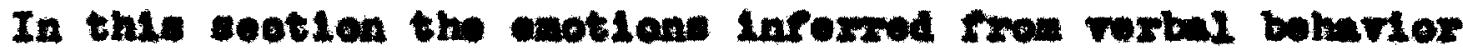
In total context will be disoussod, both thoue whioh initlated interwotion as well as thoes apparentiy reauling

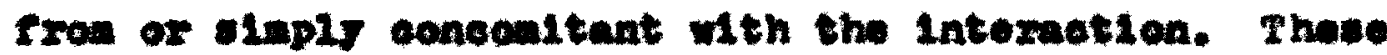
enotions w11 be rolated to the sotwal centent matrial

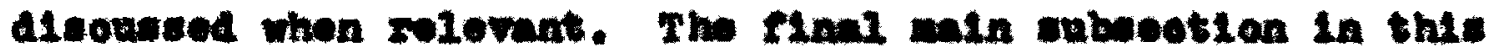
ohaptox, 1.0. VI. Combir aruLrsIs, W11 contaln *

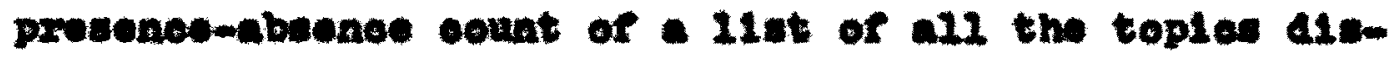
oused by oach gxoup. Sinos those top1 on miated to onotlonal exprouston w11 be alconaned hore, there 111 of noousity be allght oreriap.

It w1II be ranonbered that the KDHS-SG eltuation wan woh that the expreasion of enotion, 1.0. "getting on the enotional Ierel" wa nelthor onoournged nox dseournged. Thore was no attenpt to Intenglfy Involvenent or

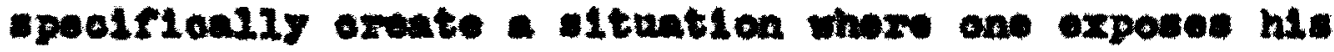


problows or his feelinge, as is the case with wany ourmont group atudies. It 1s, however, basio to the theory behlnd all projeotive teohniques that by doorbaning the struotuze

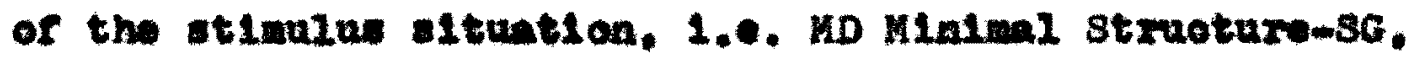
the Indirldunis expesed tond to conplete the lnociaplete whole. To do thie thoy axan on tholr oultural backerounde and Individual permonalitiee.

The oultural bolkground and individwal perwonalition are corted by using the wane teohnique as hal beon used on onoh of the othar vubeotion of chapter III. Enotlon unique to we perton in a exoup are oonsidered Individual. and wationed a belns unique to the sample. Those anotion comnon to monbox in both gropp are consldered ralated to a altuation alailar for both groups, auch a thelr belng foxel ga atudente away from home. And thowe - motlon comon to monbaze withln a group. but contxuttins Ith those emottons commen to menber of the other croup. aro comidered dietinotive for the croup and rolated to differwnes in seleotion of anple. In this onse ethnio orfele. Fuxthor Aleovedion w11 appear in the disouselon ceotion.

The enotlons wore inforred froe the benather. prinelpaliy the rerbel boharlox, of the sxoup partiolpants. The terw Inferxed is uned for two reasons. Plint, beance

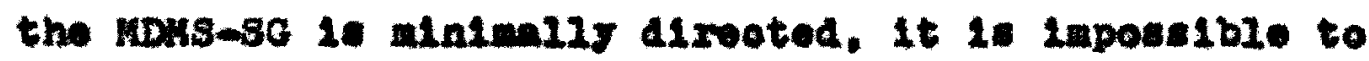
proserre the alnimal diroetion attribute and elmultaneounly 
probe. Interpret and cheak one's Interpretation of onotlon. Becond15. the Investignter antegorised enotion In Englinh teren. Fhore 20 no reason to aseune that what has been

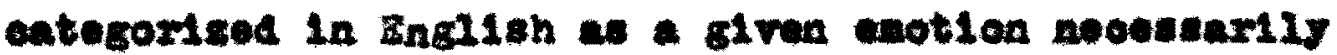
atches the Armblo or Japanose category. One proanably Ienres to Iabel his own exotlons by bolng told what ho 10 feeling based on wowone lbe's observation of him in a total sltuation. When Iabele for omotions annot be Alseot2y transiated froe on languge to another. It is 11kely that what is antegorized within a lebel aleo

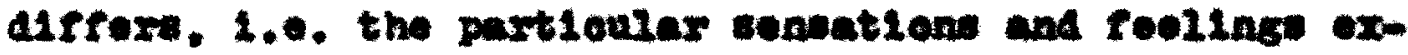
portenced. Whioh emotion: expmereneod are exproseod and how they are oxprouned an also diffor from oulture to oulture. and the way in whioh thoy alres has othnologleal signirloanoo.

In this study the 2abole used. 2.0. the universe of feellage or enotion used for the beharior obeorved. Is

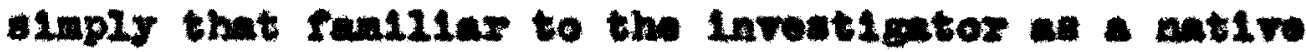
opecter of the Englion Inaguage. Sinoe this is a postontegorization, exploxators atudy, nelng one of the orten ueed linte oould alegules the unlquenese of the differonese between the twe group. In adation the avallable liste

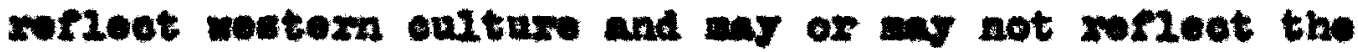

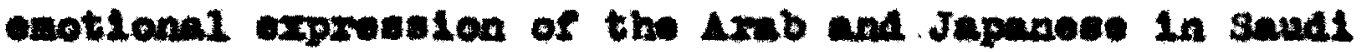
Axable or Japan or the spoirls Armbe and Japanese inrolved in this prosent MDAS-86 researoh projeot. 
The twelve rooorded tape were lietened to, and the Invoat1gator attempted to underetand. Iabel, and oomp1Io a IIst in Eaglish of each difterent reeling exprossed. In aldition to the verbal ones on the tepes, observations made during the eotual grovp seaslons wero rosorded in the rield notes. Additional oues other than rerbal oues also communasted enotion and $\mathbf{1 1 2}$ be mentioned whon pertinent. There wa no ettempt mado to do an in depth analyale of unoonwelou motivation or to mire eduouted cunsees of intennity 10vols of alnimally exprosece enotion. Only thoos obvicus

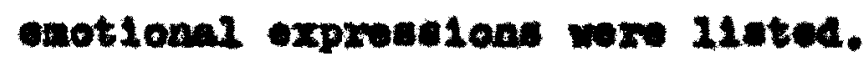

Three 110t: wil roliow. The flrut 11at inoludes those enotiont and reelings comon to both groupe. Whan an

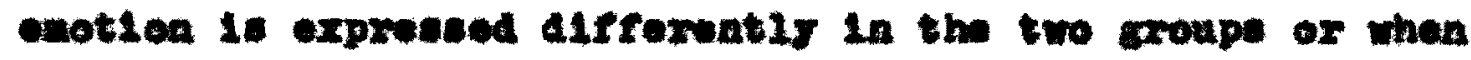
wone reeling in eleaely anoeleted wth enother foeling in one of the two groupa, thila w11 be antioned.

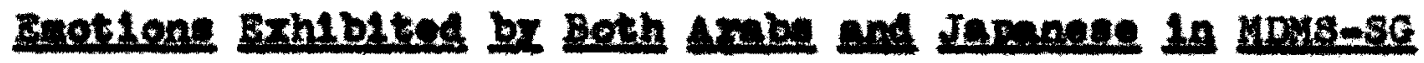
Both groupa exhibited.

1. Nostalgla for the fansilar oonory of thatr howeland, patt sohool life and excuratons, inferxed fron conteat. raolal exprosalons and tone of rolos.

2. Longlnge to soe thatr fallies, verbalized as

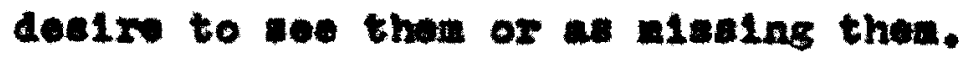

3. Huager for faverite national foods. This is Ineladod a a feoling boause it was awelt upon by both 


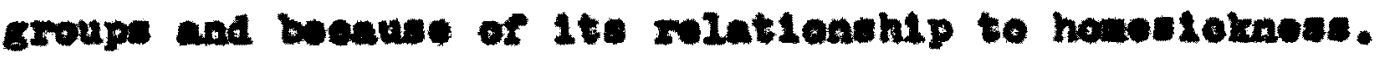
In nolthex croup was it aseodated with itose one or two

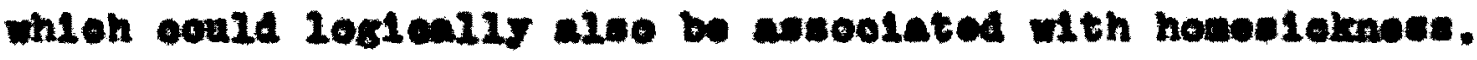
4. Boentaont. Inferred by alseuselon about discourteous treatnot and Inok of inoers interset shown to then by Amorteane.

5. Fxide in tholr fandiles unown by tollins of peot achlorenonts and honoxw of fandy menbers as well as by charing parte of woont lotter and nowapaper ollpplnge. (Thle we noxe froquent in the Japanoes exoup.)

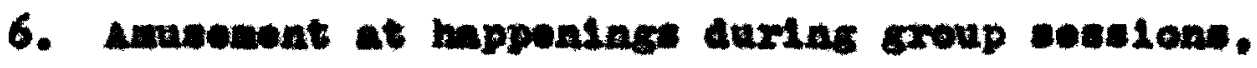
Intorred from andies, oheokies, Gedoe or Iaughter.

7. Pxlde In tholr howoland and anotent history and elvilization. Inforrod from oontent in both groupa and rerbulized at prial by the Ambe.

8. Recitive onetion soceolated with alsounelns thing they 11 wo andor approve of, Inferred from roloo quality and conornd donecuor.

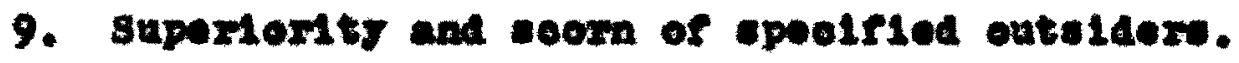

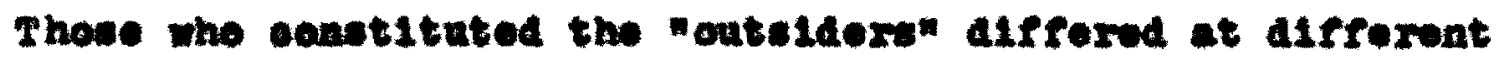
tiase and for each sroup. Thls we lafexred in both groupe from both coatent, and enanors of opocklas. In tape J2, g. sare. "I think Anortion Gire aro 2aok in coanon

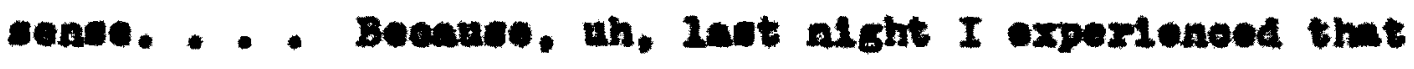
one of 18 roonmatoe' fxlonde one to our roon at 3,00 in morning." I. enre, Hina" (In disapproved tone). Thon H. 
continues, "And ay roomete ase obe continue talkine "t1d

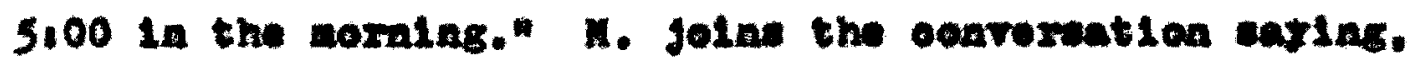
"Hen." Thon H. eara, "It we although thor whrepered it anros to very 1rritated. I didn't ear anthlng at all bat. (pauce) Japanose glrle aover do wuoh rind of thinge," $y$.

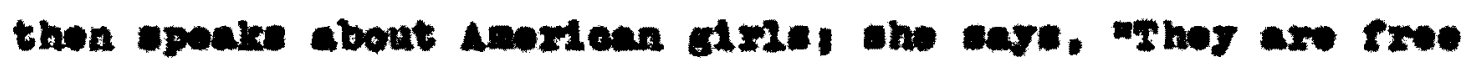
froa fanily, authority. . . they are crods." H. roplles, II wos. but you can undoretand, glrle 18 do not do that lind of thing." Although both croups peces judgente

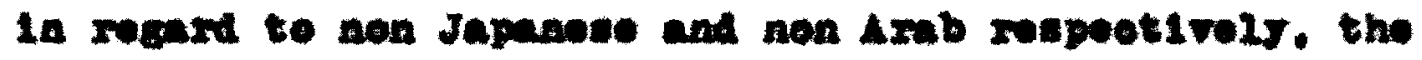
Arwbe did co worv often and wh grouter frodon.

10. Bonign onv ecmblnod with adnimetion of epeotris Amoriean convondences, ofrielont ritohon, ote. Ihie was Inforrod frea verballand pralee comblned with stateneate of with and/or desire.

11. Strong enphamis on thadr 14ent1ty at an Axwb or Japanese. This wa nore often rerballsed by Arabe and we acoanpanted in tho eave of the Amb by rerbaligutlow in defente of Axb henox. Awong the Japanese the feelinge of

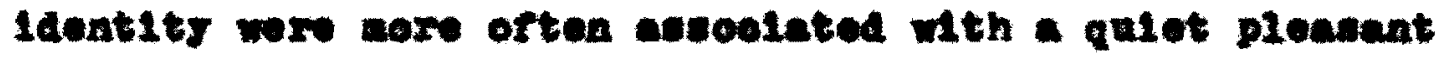
anotion inforrod to bo contentant.

12. Curtensty about the Ilfe of the fadiltator. The Arabe exhibited these feeling eore froquentif than the Japanese and it wa exprosed by both is the form of queations.

13. Worny and concern, these exotion nere rexballsed 
by both groups. They oould also be lnfermed from the oontent anterlal. The Arabe and Japanose showed concern over different toplos. Iho Japanose ginle were oonoerned ebout the1r opportuntties for marringe belng endangered by thelr

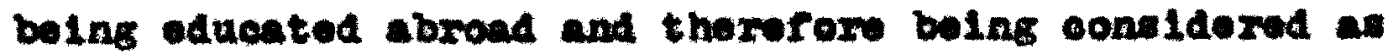
Inoking in tradtional virtues valued by the Japanese sueh as enrneas. Armbe were worried about tholr relationahip with thatr rathore. A disenesion of the apecifie vorries and conoerne w11I be elaborated upon in VI. CaNTEHr ANuIYsLs.

14. Bubarmaseat. This we rerbelised in the Jepanoes group and in both groups inferred from behaviox whloh ranged fro glgslos and ahteting in oas's seat and oesting the downmerd to slumpling, blushing. and oovering the face.

15. Anger. Anger was not verbalized by olthor group. Anger we Inferwed the inveatigator from oontext, Inoluding oontont. body movenonte, faolal exproselon, and roles quallty. In the Japanose group only three of the

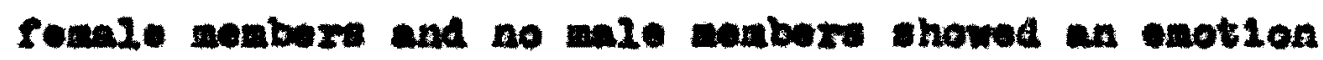
labelod by the Inventlgator as anger. Thekr voloes beane tense, high, and wore forcerul. They ald not frown or wore qulokly. The Ambe seonod angry muoh nore than twlee ee often as the Japanese and for moxe extended pexiods of t1me. Thoy apoke loudly and oxphat1oally. They ropeated otatononts, mintalned ore cantaot, frowned and wored thoir 
axws and hande with atrength. Two Armb ongaged in sulking bohavior. 1.e. both ant quietly. al1ghtly elumped with oyes arerted. One ade commuts to the Inveatigutor as he was learing that it we polntiess to argue with the sposfio person toward whom he was rocting.

16. Irxitation. Folling imitation wie rerbaliy exprosed in both groups. Menbers in both groupe were fruatrated beouse thoy were unable to way what thoy wanted to way in English. Moubers in both groups woro also 1rr1tated at happeninge oopurring outalde group sesulon. The Japanese In addition rerballzed that ther waro frustrated bocane thoy felt that in Englioh a conpared to Japanose there 1a 11tt2e relationohtp botween form of Iangunge and the statue relationohlp between apeakers. Thoy wishod to exprese feellage they could not edequately oxprose in Bnglieh boante Englion 2aoke forme and word marlety Inhorent in Japanoee.

17. Borodon. This was not rexbelized but inferred from phyateal boharlox. Honbers of both groupe looked off Into opace whon nothing apparent we happenins. The Arwbe often drumed tholr ringers, anmpped their flugere and sade varione noteos wth the ohulrs in eddition.

18. Bxoltonent of gortul variety. This was obeerved by the Investigator and sot rexbalized by the group partielpante. The gxoup aonbers looked happy and epoke ropldif for example when thoy sound that the Investigator hed vialted 
their hoseland or opoke a fow worde of tholr Iangrage. ThIs ocourxed aleo with both groupe when thoy talked about places to risit in thalr countries.

19. Diebolier or exprise. This wan verballsed in both sroupe and accompanted by different tones in rolee pltoh. In uddtion, the Arabs mined oyebrows and raleed the ohin thoreby throwlag back the head in a oharmoteristis gosture moaning, "no."

20. Tenslon. Tenslon was never verballzed. It was present in both groups, but moxe evident in the arab group. It could be obearved by liatening to the 1 ghs, ohanges in bronthing rates, throat olearlug, and seeing extraneous norenente or tense postures.

21. Shook. Shook was remballzed onoe by one person In the Arab group and once by one person in the Japancae group. In both asses the other monbers 11etoned sympathetically and ouppoxted the ahooked Individual by agreelng with his. In esch ouse, a pate experienoe was rolated with strong roeling. An Armb boy sald he would never warry an Amortean glxl beanuse he had read in the newspaper about a woman who rorused to allow hor former husband the r1ght to soe hio oht1d. Thla soemed a torrible thing to him, and ho rialbly rosoted while relating the inoldent. One of the Japanese group, a young woman, had been giving a sanal Ameriean-Japanese girl Japanese Ieasons, and the ohlid sald "Anata dame de" to her. This means "you are bad," but it is 
- form not used by ginle and espolalis not dirooted tomind en older porwon. It partioularly shoukce sad upeot ber.

It oan be eeen by perreal of the above 11st that

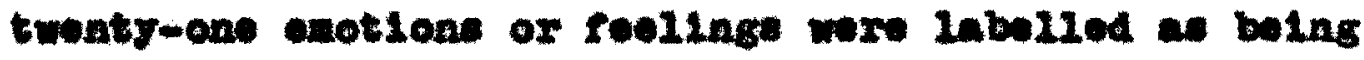
cownon to both groupe. It 18 alwo obrious that of the twatj-one, two onotion, enger and borodon, are oxpresesed

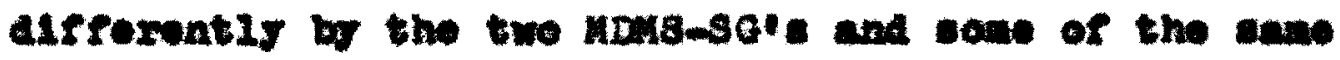
obotion ocour in Afreront envizonente. 1.0. worry and conoern and angor. The Japanoee wore nox Intensely

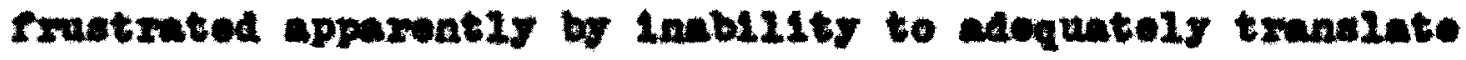
Japanose thought and enotion lnte gadiah. Alao tho foolIngt of idontity expronoch by ocoh group (which any or any not be an enotion por sol aro meodated wth a difroment roollag tons.

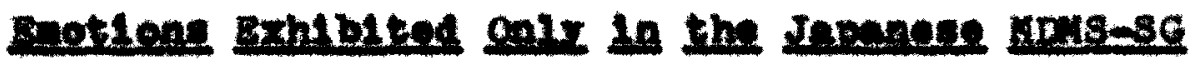

Thare are only olx onotions in the llat of anotions exhibited by the Japanose nDHs-so and not the Amb MDHS-SG. These are.

1. Strong and ropented realing of soselt17ty (ponatbly foar) al to how another croup nouber or the faoliltator would ronot to what wa bolng sald, 1.9. a woxy about how 1t would be takea. This wa rerbalized. Tho

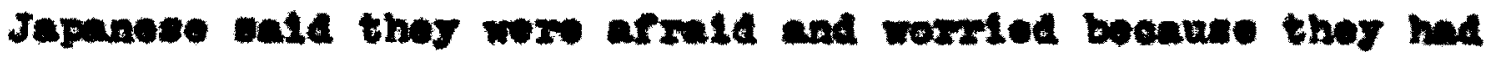
"ald bad polate about tho United stateg" to wo. Inis wa oxpreased lamodiately arter one fomele told wa that hor 
frlend who had "ade the bad polnte at a provlous neeting" we too tirod to sone todny. The foollitator had onjoyed hor and the disenesion. The Japanose croup nonbere present soosed gonulably glad to hear this. In op oave, what wa interpreted as foar wo obeorred when a tomale was tomporamly consored by the group. Sho had arrived late and she had exprosed hor perooption of a altiation whioh was rexy differont from what overyone else had exprosaed provioundy. All the othore jolacd to an that they riowed the altuation alfromenty. Iler rosotion to their united dieagreoment was Intense.

2. Proferonoe for hrmony and agroenent verballzed and obeerwed bohatiermily. 1.e. thoxe wers alnost no aggroenitre Interohanges.

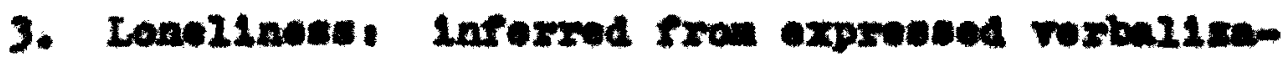
ton ony. (The Ambe ald not rerballet this.)

4. Foollnge of shrness, verbal1sed, (What was vorbalized by the Jepanose in the sroup as ohynose, seomed to the inveatigntor to laolude foelinge that English epoukere connider to be rolated to modosty in addition to

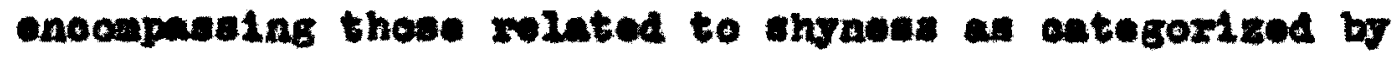
native Engileh opeakern.)

5. Benlstanee to 1090 of traditional Japanese ralues. This was verballsed by walos and fomalos, bat nore omphationliy and rroquontly by anlos.

6. Desire to use honorifies non-oxietent in Bnglish. 
rerballzed.

Enotione Exhlbited onk in the Anb ypus-SG

Thar wox twolv foeling or enbtions labelled by the investigator whioh were diatinotive for the Arab group. Thor Inelude the rollonting.

1. Opon ocapetition! nover verbalized but orertiy obeerved. The Areb combere who were rexbel interrapted each other froely and alfferent nenberw at different tinos direoted the oholoo of toplo or Iled Ith each other for expreanion of a polnt of view.

2. A "ohooring up on" anotion. Thos exhibitod a foollng whioh oan be explained but for whloh thaxe is no single word in Englioh. It 10 aldilar to sumpleton and

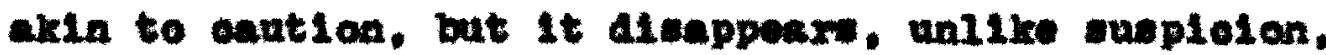
innediately after an explanation or information 1 rooel red. This anotion seene to involve a nod to know what is golng on bofore they and comfortably partiolpate in a givan stuation.

3. Sensitivity to inoult fron othere. Ihis soneltIrity wa rorballed as an Arb tralt and agreed upon by the nombers provent in the ecesion during whloh it was disoussed. Howerer, what conotituted an insult wa not speolfied desplte requeste for olarifioution.

4. Lojal natlonalion andor patriotian as suoh. Ther rerballzed love of thalr howelend at woh and pride 
Io being Arab, what lght bo desoribed as almost a miltant quality. (The Japanase exhlblted 1070 of thinge Japanese but did not verbalize pride in tholr homeland as suoh.)

5. Feellngs of haring been misunderstood, insulted and ohoted outelde the group sessiane. Those foeling were rerballixed and In addition, one nomber verballzed that he was belng sisunderatood by othor members of the exoup. (Another group member had oallod hin a hypoorite.)

6. Pear of the power of the fathax in the fatherson relationahip. Thle was disouseed serlousls and with exalted ooneern but none of the physical oonoodtante usually assoolated by the Investigator with a fear rosponse were obeervable.

7. Fooling of noceselty to ohange their mays of reoling and thinking in respot to male-temale reletionshipa at least while in the United statos.

8. Open host111ty. Host111ty was novor disoussed as a top10. Hamo-calling, aocusations, refusal to ropeat a sontenoe when someone domanded 1t, and maxing show of not I1etening when ecmone elwe was speking each ooourred at least onee. Related perheps was a rooling labolled as bitternese by the inrestigator coourring in one quiet inalrieual the ellently ourled hlo $11 \mathrm{p}$ Into a sarilng exprosation severel tiase in suoceselon when the object of his nogatire enotion wa engaged in looking in a difforent alreotion. 
9. Defenaireneas. The noed to dofend one's poeltion and ldeas was rextellzed. The aotivity ooourred in onoh cession with and without what the investigator oonuldered to be adequate provecation.

10. Protoronee, and noed for pregrese, moderaity and ohange. This wa rerbalised and inforred frou oonteat.

11. Hegrot. This wa rerbelised by ono arab in two

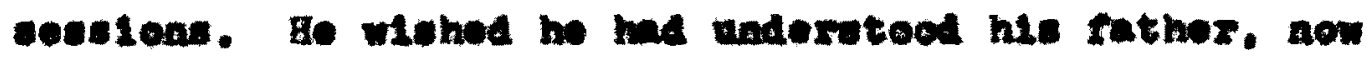

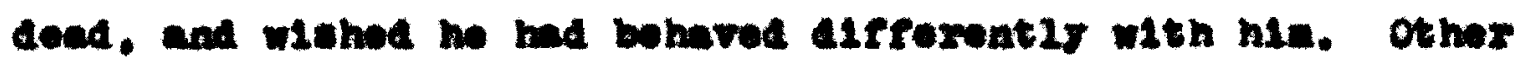

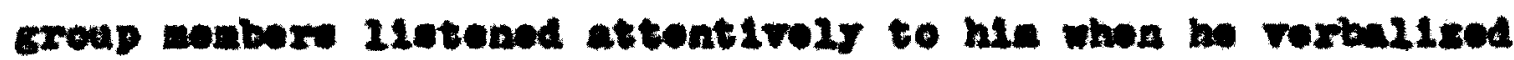
this regret.

12. Beotional sooptance or Intennity of enotional

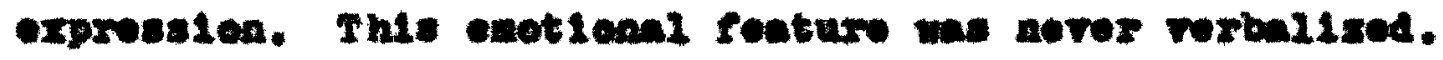
It we Inferrod primarily beause the lerel of onotional exprosesion for both positive and aogative onotion wa moh nore Intonse than that for the Japansed greup.

\section{Sunary}

To suamarize, the invest1gator attoupted to vaderatand and compare what enotlons were belng oommunlouted by the Arab group and the Japanese group. Underutanding and glring labele to eactional oonmanioation is always fraught with complication: because of the nature of the subjeot matter and of couree the notivity is even more oomplex aoross oultural bounduries. Never-the-1ose, as might be expected. giton humans in a minalig directed minimily 
Btruotured small group situation, all of whom wero forelgn otudent a wo know eaoh other, expeating to return to their nat1ve land, to. they behared and/or verbalized elmiler -motione similariy in oertain reapecte. Fron this boharlor and these verbalizations both groupe were labelied as exhlbiting and/or verballeing roelings of nostalgla, longing, apeolete hungere, rosentmonte, rauliy pride. national pride, amuesent, generallized posttive and noget1re exot1ans, superiority, benign envy, ethnio ldent1ty. ourloelty, worry and oanoern, ombarrasement, anger, 1rritatlan, boredon, exeltement, disbelier, tonalon and shook. of the twenty-one esotions expreseed by both exroups, the Japanewe and Arabs oxpreseed anger and boredon difrerently and showed worry and anger is aseosiation with afferent toplos. The Japanese wore more intencely trantrated by langrage Inequiralenoes than the Armbe. Both while strongly ouphulelng their ldent1ty as Japanose or Arab, did so in alfferent manner.

The Japanese and Armb groupe oould be olearly differvatlated on the basis of certain emotions verbalized In one group and never verbalired in the other. Iho Japanece alone verballzed otrong eneltivity or rear to othere remotions to tholr bohavior. proferenoe for harmonlous relationshlps, Ionelineas, shynoss, resietanos to lose of traditional Japanese raluws, and a dosire to wo apoolal reapeot language. 
Only the Arabs exhibited open competition and an onotion elaliar to eusplolon. Only the Arabe rerballzed

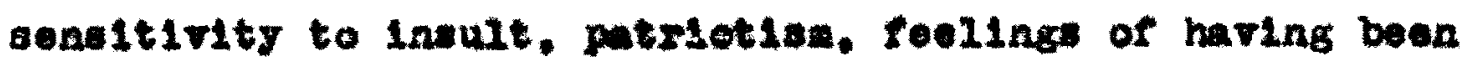
mounderstood and ohoted, roar of their fathor' power. desiro for ohange, a noed to tomporarily at least, ohange tholr thinking about man-woman rolationships, desire for progress and ohange and also regret expreased by one individaal twlos. Only the Armbe showed open hout111ty. open defeneivenese and an sooeptanee of latense emotional oxpression. These onotion differentlating the one group from the other w1I be further alscused in Chapter IV. THE DIscossion. An analyele of the subjeot mattor diecussed by the Arab and Japanese nDMs-So w211 be presented in the next and rinal subeotion of this ohapter.

It oan be aeen that the MDMS-3G provldes ready access to onotlonal analrais, a type of data diffloult to obtain by uaual anthropologleal pothode and therefore it is uesful as a supplenentary tool for providing a moro complete underatanding of a oulture.

\section{v. conrswir antutrsis}

The subjeot matter mentioned in the sesaloan of eaoh group was tabulated. Induotively olaselfled (using the aforomentioned post ostogorization tochniquo), and compared. S1noe struoture and direotion were minimized by the facilitator, It follow that the oholoe of toplos for disousalion 
belonged to the eroup wonbure in both arenpe. Thte faot onbled the laventigator to olearly diffoxontlate that oontent which dictingulahod the Arab croup fron the Japanose group. Tho diffaronoes dertrod rrou the wee of this athod ohould be relowat to an vaderetanding of the difforential oultuml condtiongng involved.

Th1: soetien on content andyole whI sonelot of three coin parte. Thi rizat ain part w112 oonilet of a 21atlng of those toplos whloh both Amb croupe and Japa-

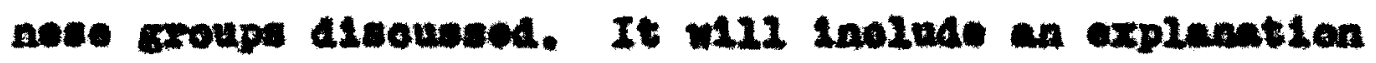

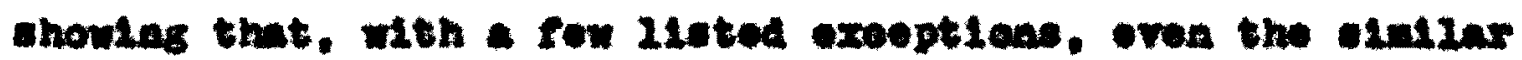

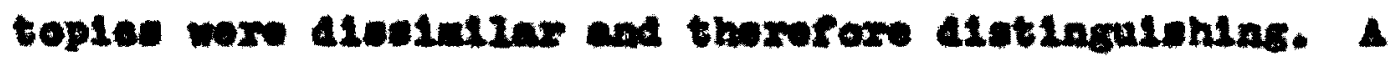

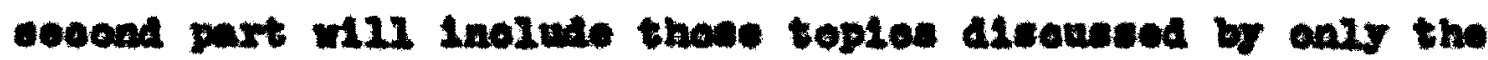

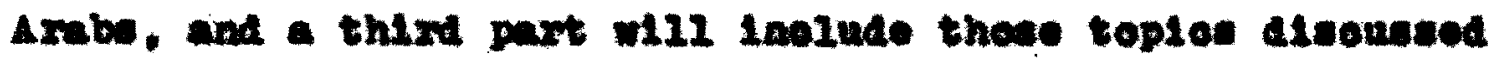
ons brethe Japanoes.

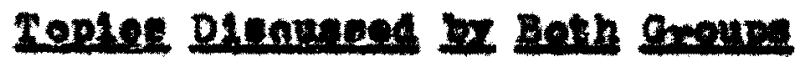

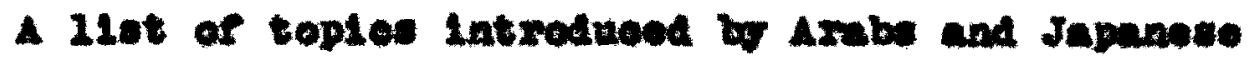

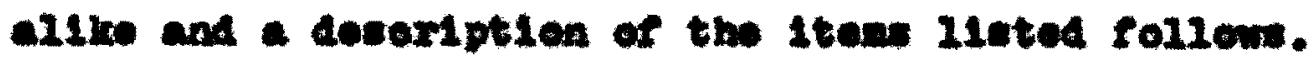

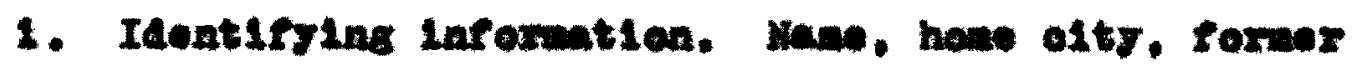
sohoel. 2ength or time opent in th United stetes. prosont restenes.

2. Quevt10a alroted temmid fooliltater about hor rand1 and hor inproselien of thelr countrles.

3. Problew exporteneed.

4. Dradie seintionhtpe of inportanes to then in 
tha1r homelande.

5. Fanily atruoture, roles and afrielon of labor whin the randiy.

6. Roligtan and equeation.

7. Btbnie laentity.

8. Nat2re rood and 1 te proparation.

9. Cuxrent witlac gjoten in tholz countries.

10. Wathor.

111. Hatiw holldaye and oelebetions.

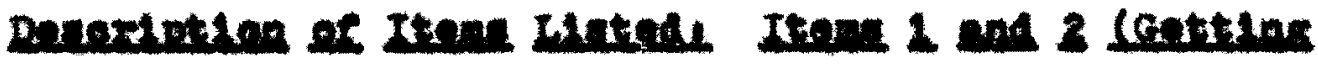

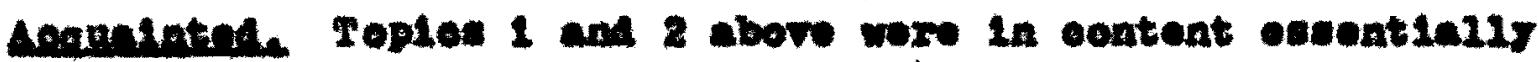

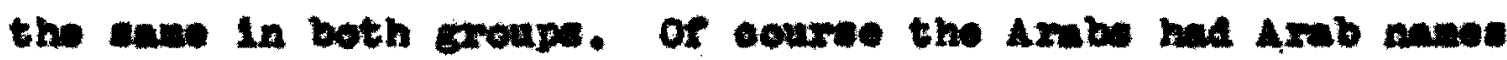

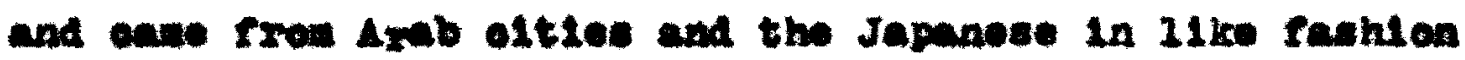

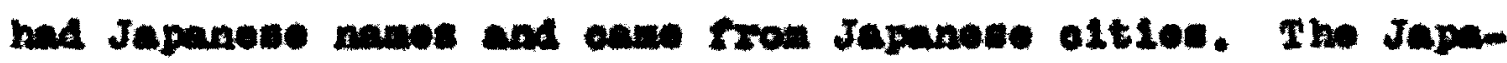
neve, so proviound stoted, alway Introduced thoneel res and the now frlende they brought opontanoously, whlle the Axabe. Ith two exeoptlon, gave tholr nanes only whon soked. Iho

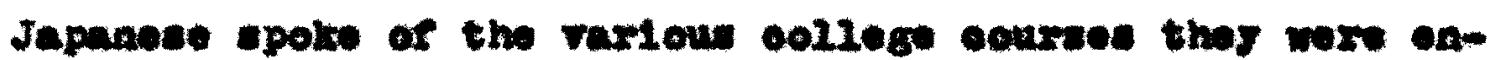

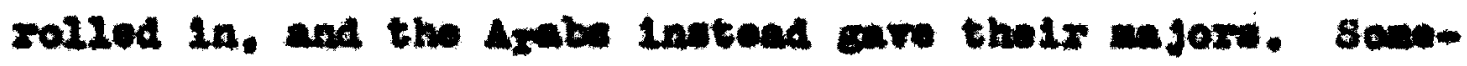

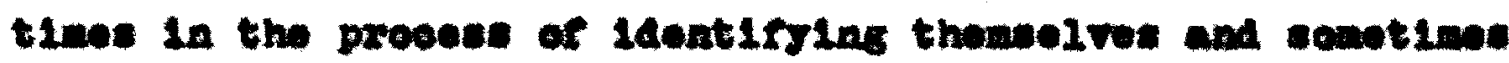

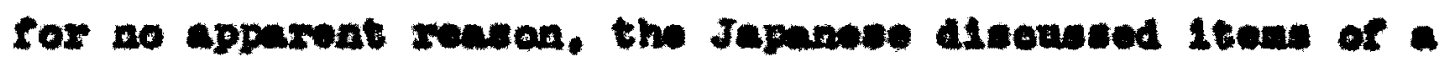
persend atuxe. Exch at the Japanose olube they rad been mobers of. tholr faverlte epoxte, and muslo, and thatr

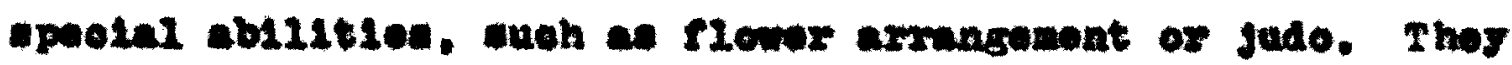
epoke of perwonal thing abont thair rank210a, 1.e. the brothor of one movber wa bottins married, sonoon had a 
blrthdy. sonoono's crandnothor taught tea oeronow. ote.

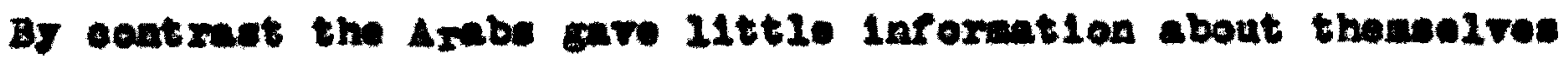
as Indiviaule exeopt by wy of 111uatrotion whon a sonoxal tople wa prosented for alwouneton. One young man, for exanple. told how many wires his fathox ha, but se art of - diceunelon on marriege Iave.

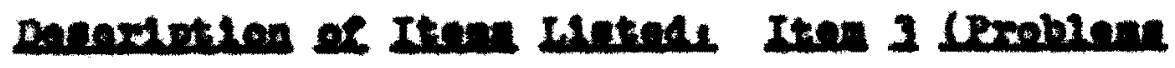

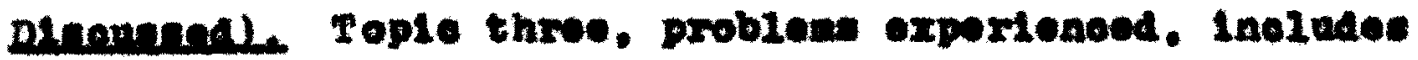
abtoples and tharofore requires explanation. The Japanoce and Axab groupe in the prosent atudy ware not problemoriented groupe and no attenpte wex ade to alloriate tho

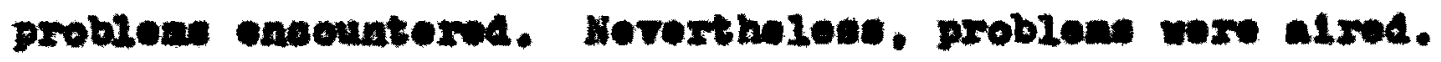
Meat of those wore related to tholr adurtuonts to oultural conpllete and tholr conatifitien, and the form of adaptation choos were for the nout purt alfrexuat for tho two croupe. Thore woxe corteln almilartelos. howovor.

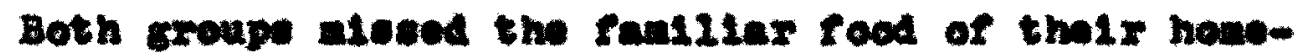
Iand and ha diffiouties adjuting to Anerioan food. Both

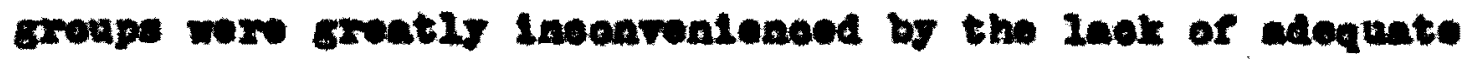
publis tranportation, and, In sddtelon, some of the Japa-

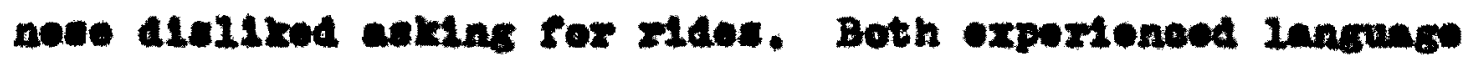

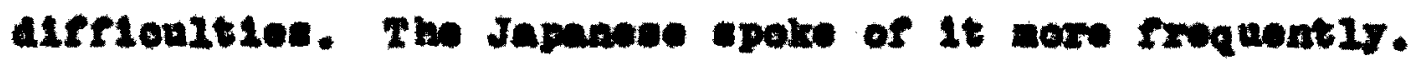
Individuale in both exvop be trouble eceplettas roeding ensigments. writing osong exwe, and talling with arivere

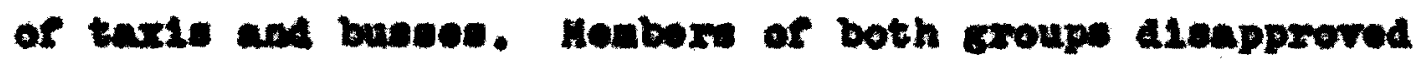
of the diseourteor and inpatienoe diaplayed by elorios in 
otores and Indirlduals with whon thoy oase in oontaot in the prooses of rinding thalr way about. oopeolally in conneation with bueses bat aleo in the provese of finding both temom raxy and soni-pormanont hotaling.

Wh11e both the Arabe and Japanese in tholr reepeotive Group alseused problons. som problens were brought up only In the Armb groupe and some only by the Japanese group. Those probions intraduoed only by the Armbe follow. The Axbb atated that ther folt tlat thoy wexe and to foel stupld by Aorions when thoy alkod for holp or dixeotlone. Two of the Amb atudente reported that thay had been robbed in Hew York (tholr moaes and olothos were etolen). soreral Ambe wated to 14 w wth an Anorieas ranily they unde to learn the ountom and Iangange of Amorien botter. but woro uneble to find howes. sovarne jolnod in romarking that tham wa no plaes to pring excopt in thelr roous as oxogon has no nowque. Ther agreod that a enjor oultural difference ma boy-girl relationohipe in Aeorlea. Thoy cald that thoy ald not know how to aot haxe toward wowen and that thoy eren had to learn to think differontly. Many were inrolved both during and outelde the group nootings in what

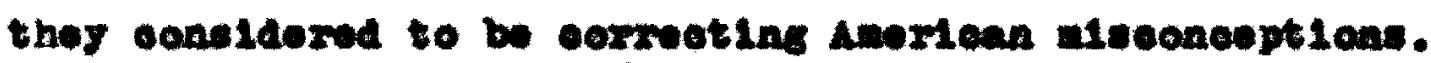
The Axmb croup nomber. agreed that Axab young apa in conexul

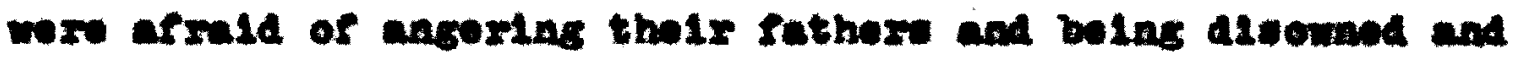
dielnhorited as a rosult. At tho sane time spoesfle croup neabors stated that they wated to ohange tholy fathors.' 
oplation and dimotives. Thoy ackeed that worry about belins pxosenured Into marriage by tholr parente was rexy roal to a

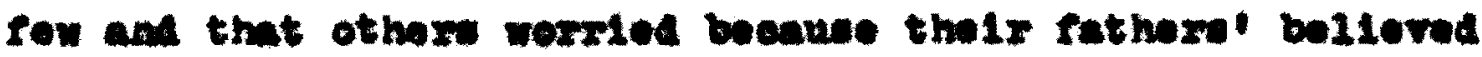
thot to disobey want that they laok reapeot. Thoy wated to roupeot tholr fatherw bat at the save tine folt that thos wated to do what they thomerezres deolded wa bot. Thoy aloo wated to oreate ohnges both here and in saudi Arable and oould not agree on tho wothod. Soveral mentionod tholr cleters who 1ived in saudi Armbla. thelr eloters' eduoation, or the wien thit thalr eletorw alght have a fullex. 108 rentrletive 116e, whout ineurring ensure fres other

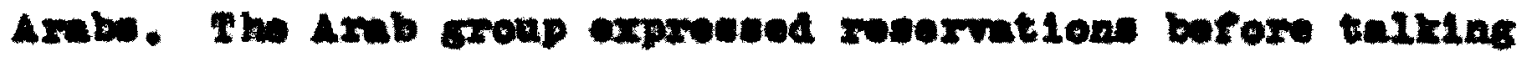
1n Ireat of the feoliltatar ebout the generetion gap betweon

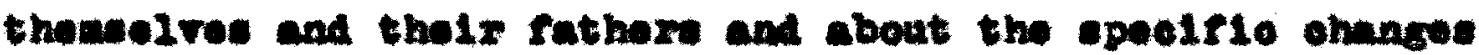
thoy wated made in saudl Arbbla. Thoy dicousach tholr reserration in Baglieh anons thomelves and deolded it would be alright to talk.

The Japasese on the othor hand ald not opoux of any of thoes thinge. These toples alcowned oply in the Japroses eroupe rollow.

The Japanose boys, In contrant with the Axaba. Ald not divouse or wean to wieh for ohunge. Fhoy thought that the Amoriean Inrlwones on Japanose wonon wa bad and thoy ctated that ther wated to marry traditional wives erentunily. The girla felt that thelr opportundties for a good eatoh alght be dininichod by thelr haviog boen tralned abread, however. 
they wald that if posalble they would wioh edueation abroad for their daughters. As a croup thoy tended to think that

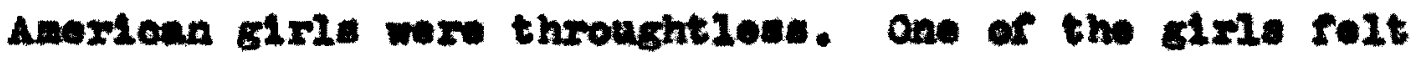
that Anorioan girle leok true friendinoss. Sho folt that they eniled and wald "HI" wth gront ease but that they wore not wlilng to lareat tiwe in etting to know her. sho had alfrlealty at Plat sotting waed to people sayins. "Eow are goup" bosaue tramiated into Japanose it would only bo appropriate if on 20oked pale or had been known to have been 111 or woovering. She thought that Amorioans anile all the tiwe and that it ant be suxfues friendilnoss. Sho thought 2t atrange that thor swoted hor whan thor did not oven know hor. In Japan ohe nover sald hello to atrangere, or oren to a friend if the rriond wa corose the stret. Anothar girl had defleulty finding Japanese frionda. Both of those glria ceoned to acdiry thelr expmesed rlowe arter interaotion with other group eanbers.

The Japanone as a group reported groat difrieulty with

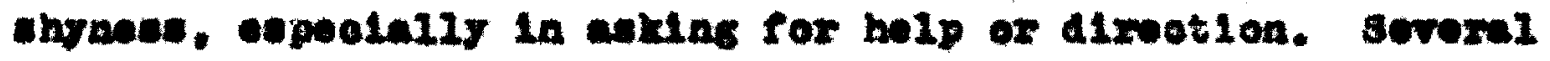

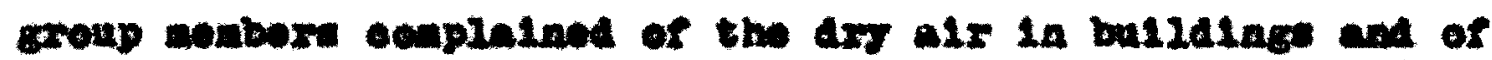
welght gan and orln problene sinos liring in the United states. Severml also wahed they oould got woile ourront

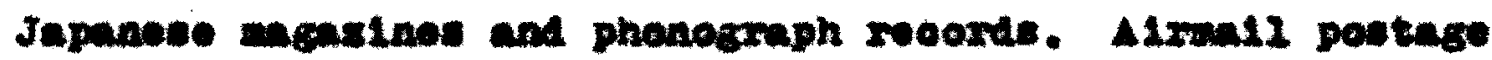

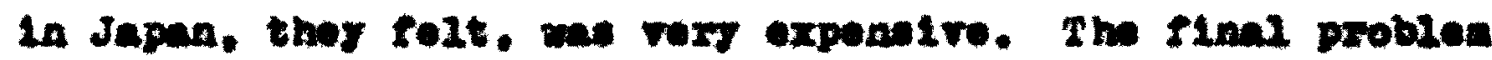

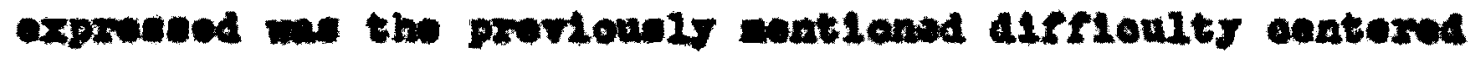
eround thelr deals to use what they allod nore formel wonde 
In English and bolng frustrated beave English leoked an equivalent rorm.

It Is obvious frou tho above Iint that although both

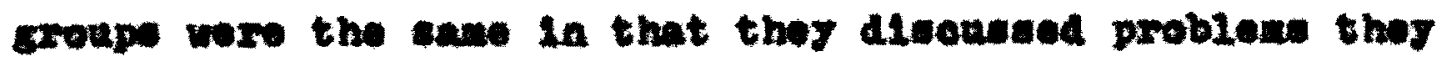
hed expexienow, there wexo cotanily only three problen which wox ldontleal, adjuting to not harlag fanl11ax

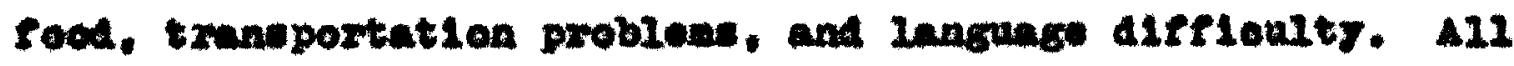

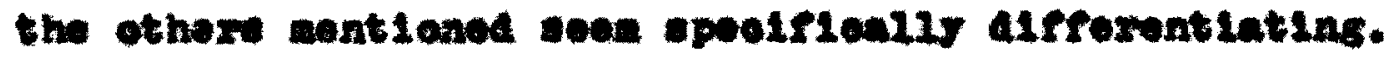
Returning to the liet of ten toplos aleonesed by both the Arab and Japaneed grouge, the last weven on the list owoh rorleat oultuml alfromases.

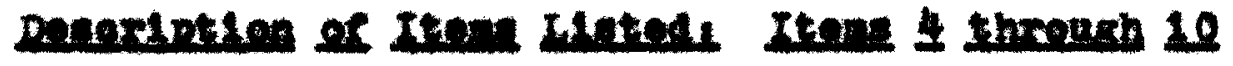
(Intex tyon). The coureational othnographio laforantion fron the two group was at conparable and inoonplete if one jodges bo outilnes orten eiven to anthropologiats to

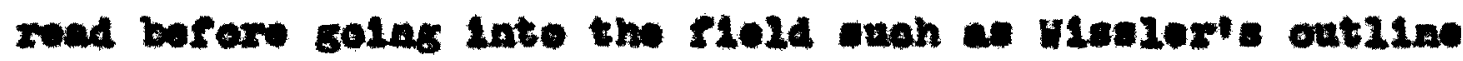
(1923). Notes and Querlex, and Hundook's out21ne (1949). While the andl exoup teohnique oould be extrenoly userul in

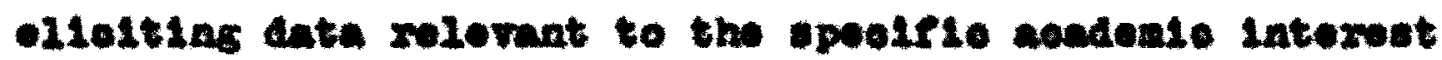
of the anthropologlet, the alatealizmatxoted elnimallyotruatured ama11 exoup (nous-sG) is not. The noms-8G cos, howerer. have the adratege of belns leos oulture-bound as tho eategortes of ante and tho opesifio date within the ontegories are of necoselty. beenues of design. group part Lelpent-oentered rather than anthropologlst-oentered. The anthropologlet oan, of couree, 11aton, observe, and note 
polate about whioh ho alght 2 ater wish to formaly obtaln nere Intormation.

Beganding 1ten 4, Aredie relationohipe of inportaneo

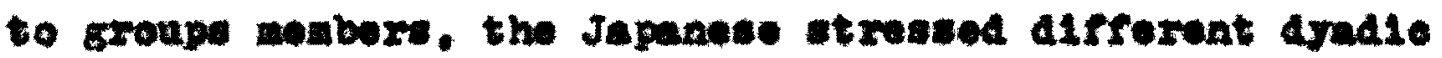

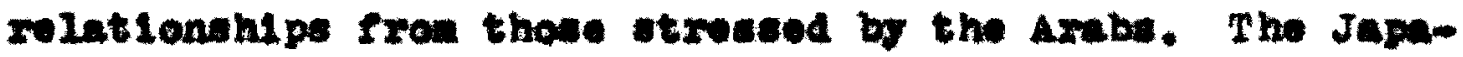

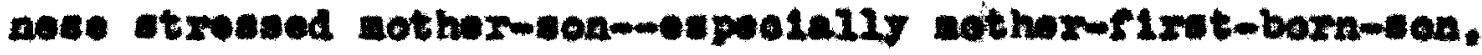

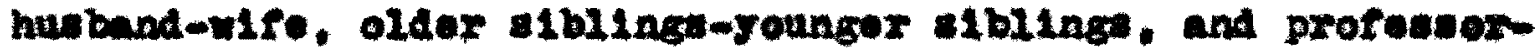
etwdent. The Arribe nont Inportant drad diseuseed seened to

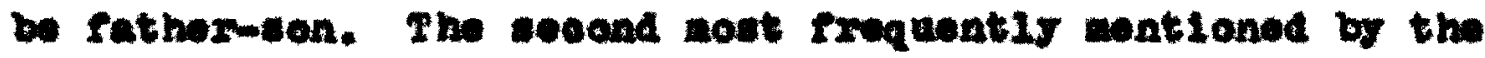

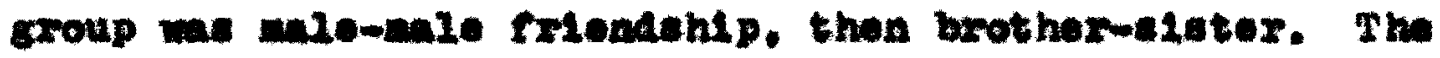
drade, fathermakghter, mothermanghter, hubund-wife and flrot-mife-othormife wo also antioned. Both groups also

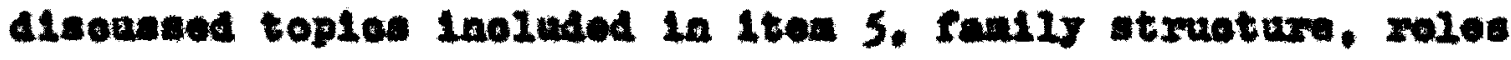
ad the altelon of labos in the ramily.

Both the Japanees and the Armbe polve of 1 tea 6 , thatr roligton. Uowally whon the Armbe opolke of Islen and the Koxan, It was in conneotion with the influx of pilerine or the bellefe of the nore conservative elesents of the oldor conoration. Whon the Japanowe mentionod roliglen it

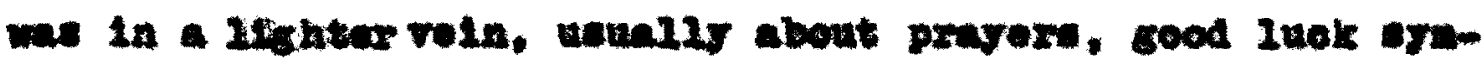
bols, beatiful tesplos with gardens, or eolerful footivale and parrades.

Both group dlsowsed edvention in thelr countries and In the United statea.

Both groupe talked about 1ted 7. thelr othale 1dentity. but the dreuselon were not couparable. The content of the 
disovesions w11 be Inoluded within the noxt two arbeotions of this seotion, Topios Disevesed only by the Arabe and Toplos Disoussed only by the Japanose.

Both groups converwed about 1tom 8. their native food, and desoribed how it wa prepared. Inoldentally, the ony oln1larity noted was $\mathrm{m} 00$, and It was propared different2J. They both talked about iten 9, their writing srstews, and Iten 10 thelr weather. The Axbe wers Interested in a rlood at the tiwe, the Japanese, In algas of apring. Baph decortbed celobsation. The Arabs talked about gamaden, a Mosion wollglowe nonth whioh involves fatting during dar21ght hours for a four-wolk perlod, and the Japanose

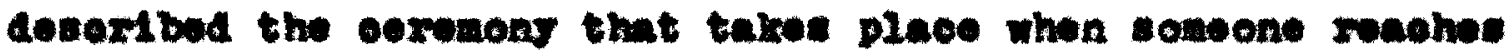
the age of alxty. Ho or the sits on a red oushion and weare a rod hat on the berthan.

It Is obviou that although oubject nattor disounes by the two groupe wes similar on one level of abstruotion. 1.0. they both talked of roliglon, they wexe dintinotive if oonstalen on a lower level of abotrmet1on. 1.0. the Japanese actially spoke of martag whes at the ohrine on Now Yoars Day and the Arabe about the power of the rellglow polloe.

The next two abbeotions w111 be devoted to a dieouselon lioting that whioh wa distinotive. 1.0. that coatent material whioh ooourzed only in the Japanese group nootleg and thon that oonteat aterinl oocuming only in the Amb 
Eroupe wotings.

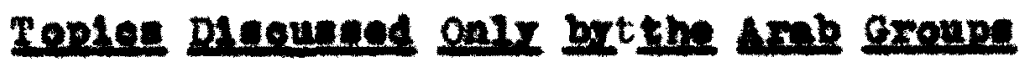

The Armbe disouseed the trecteent of roan in saud Arable and emphasised the Impertanes of roputation in tho fan12y. They talked about sone of tholy marriage patterns In the tribes. the extent and adrantages of poljener. onotonary prooddures to follow to flod a wle. uratone of naning and roppot pattorne assoelated with paves, tholr

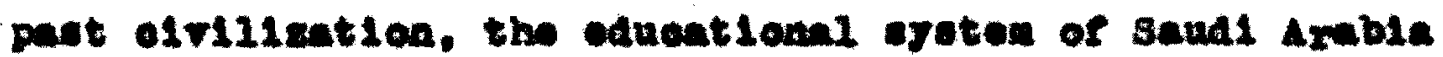
In terme of 1ta advanteges. the rntlonale bohind tho choloe of oountry and mothod of ohooming atudents to sond abread for further eduoation, the benuty apote of the Armb-world.

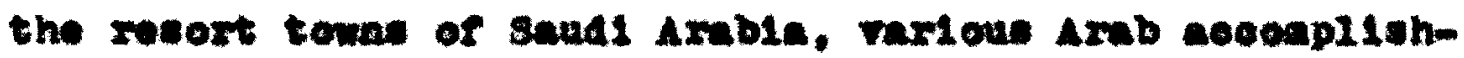
monts suoh as the now undrersity of Kumelt. the covernwont's attompt to Inoroane looal woat output, and ohangen in sandi arwile partially brought about by thelf exposure to the waye of pligrims in the western provinowe and

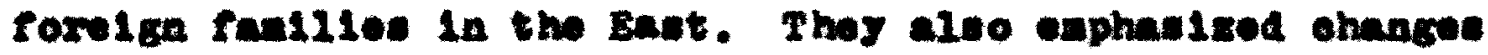
that are taking plaee in sandi amble. espeelally those aneolated with edneation and woma.

The Arabe had dilederione on the gap between bollerIng and aptualiy putting one's boliof into aption in rogard to ohange in saudl Armbla. on nothode of Influonelng the older gonoration, on the rolativity of right and vrong. on hypoorisy, on the rolative valuo or oduention and 
exportenoe, and on what thoy meant by the woxd "Armb."

Whon what they weant by Mrabe wa dieevesed, ell the croup aobbers provent folt that if somene anked thon what arv joup" thay would anower "Axwe before they thought of

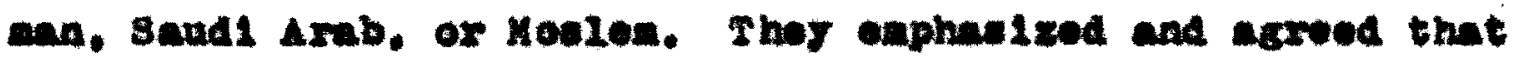
this Inoluded chrietians in Lobmon and soas Jowloh Armbe.

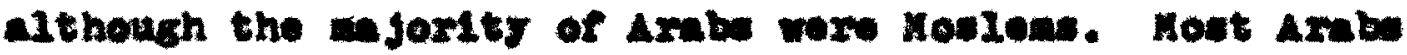
woro bern in Armb utates. opoke Armblo and looked Itro Axwb. One boy sald, "If jou'so boxn an Axbb, Jou die an Armb," In rospone to anothor group nenber'a doubt: about whother or not Amb-Anoxtean oltigon: woxe Armbe. A11

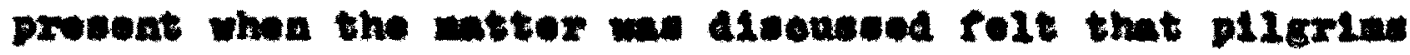

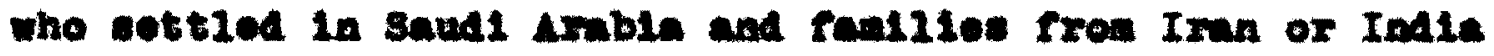
who opoke Ambie and hat been in saud armble for thro

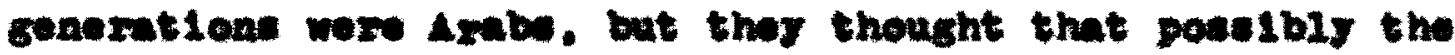
conservatives in saud srable alght net think so. Thoy aleo sald politios or 140ed are not what abke person an

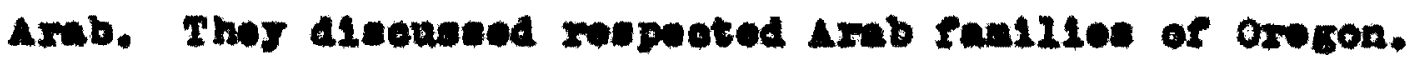

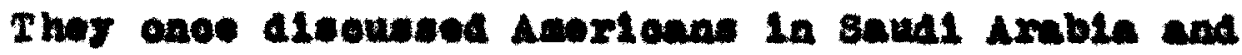

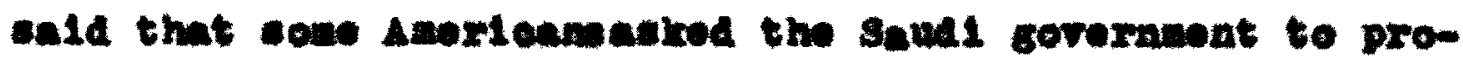

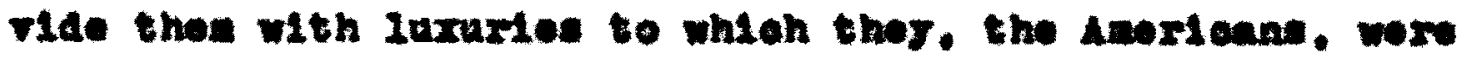
unnequstomed, woh ar koroedes, a vile and an alr oonditionor. The Armbe stated that the Anorioane were doestred eav12. Aldn't underatand how to bargaln. patroulzed Bngliab-iparing shopa, and ate roxwign food

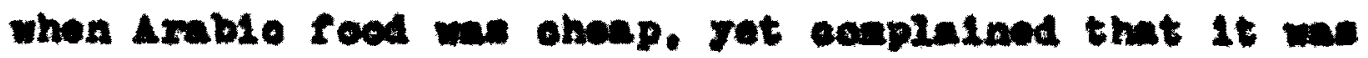


exponntre to 11 vo in saudi Ambla.

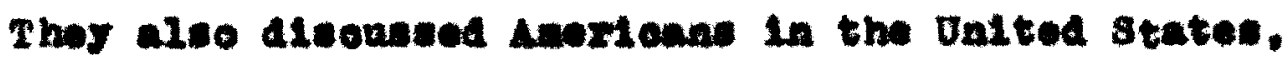
and thoy agroed that deorleans wers friendif and 1 t we not affrioult to noet Anorioan poople. Soveral wers aritical of what thoy termed Portiand State Unlveralty's faliure to expand in an oxteriy fashion and of the fallurs of pritate onterprisen to provide adequate and convenient housing noar tho sehool. Thay elwe disoweed dajilght-uaring tive, wontloned a rortuns telling gan played with oholle, domon-

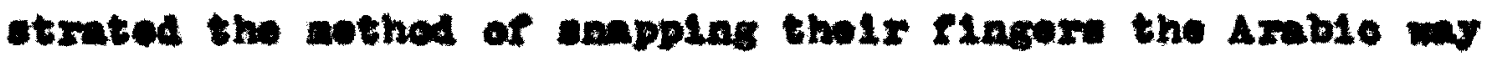
to wake a nolse, and exprened thelr dostro for ohizaren of thely om expectally bey ohliaren. Onos one boy dosoribed his oun hoes.

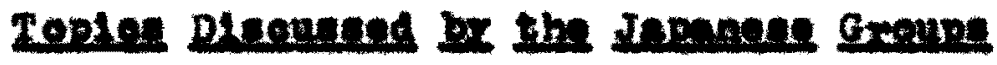

rurainc now to the subjeot ntter alsouned by the Japanose crouge, one rind thos talking about Jepanose ohtla rearing prmetteos, the nee of formel opooch, and the

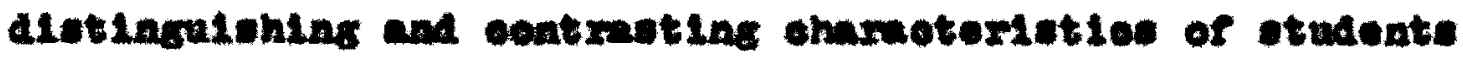
In two Japaneas colleges. Ther also attenpted to olesalfy Japanoes otwente abroed.

They strosed whe thoy called tho Japanowe way.

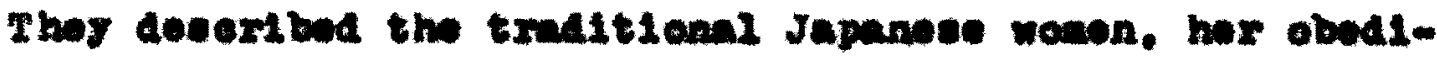

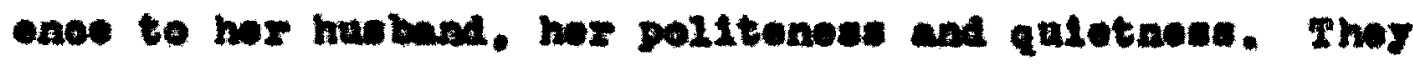

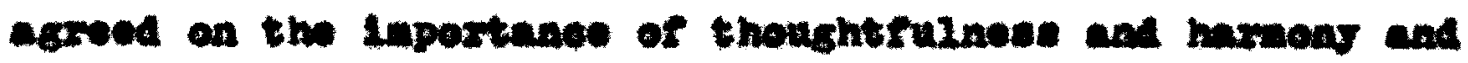
of dolns what is expoeted in tholr oulture. Por oxanple. 
onoe, hal in jeot, the faellitator wnsested that thor

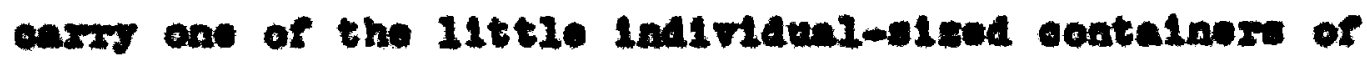
nonosodive glutanste. whioh thay thought would inprove Anorican rood, and we it on the food in the onfoteria. one boy took it sextewaly and sald. "I thlnk Japanoes bog noter do that" and a cirl seld. The oook hal soev pride

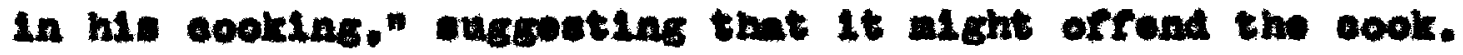
Thoy alee wontienod that thor Ilked a Mind of beaty whioh thay folt wa rarwiy underoted by Anoxlana. An oranple wa the boaty of tho rasged edges of a plees of torn papar. (Thos IIke to use haviade paper with natural pleat flbare in 1t, ald thay wot a rine bruoh with water and palat a 11ne whome thos wat to soparate 1t. They thon axrefully pall it apart learlng the irrogular fibore Vielble. Inthor than outting atmight edge.)

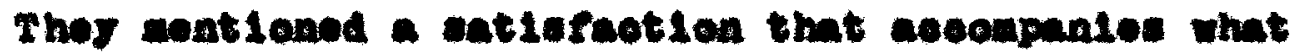
thoy toxmed the oppealto of apounulation. Thoy 111uatiated thie quality a what happons when en axtset eoulpte a statue ane the beanty monalas as the moudt of the prosese of yonorlas parte of the otone bloak. Fhis eategery is not trandateble into Englieh. Othor qualities cosoribod overLep but do not oneonpang the Englith catogories of a oplritunl foeling ooblned with elaplesty and appreelation of trudition, and lore of nature. Jepanowe poetry-eapeelally the Haliru, trealtiond danoe, enrront and pat Iftermture, and the Arwnm-1noluding Noh, Kabukt and 
Bunrake (a tractitional trpe of puppot show with large puppete) waxe eubjecte of convereation as wore modorn Japanoce mule on telorielon, a Japanese student araphoay

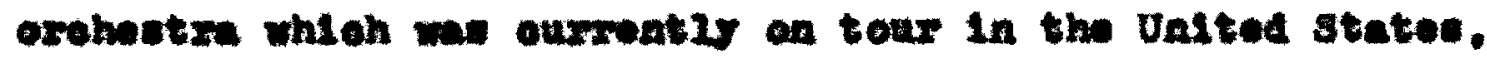
eporte, Japunoes morles and novies with Japanese cotors.

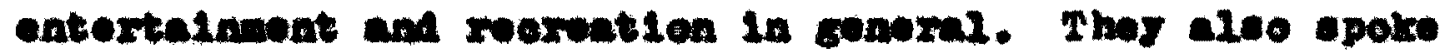
or ohliaxen's torm. and oxleanl (t type of paper rolaing).

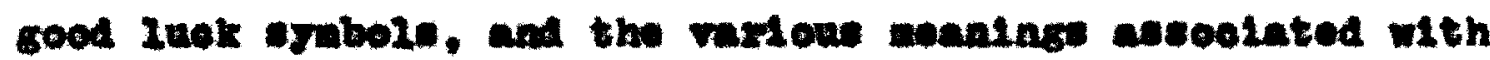

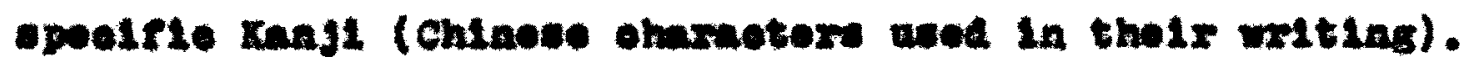
To corviong and tea bemle were talked about and thore wa Interost in the tradtional sign of spring. Thay reonlled

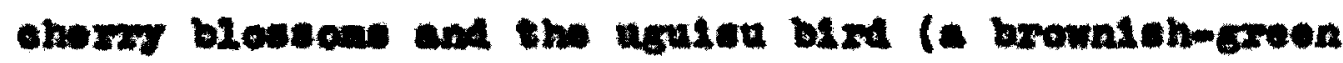
Japanose type of buh warblex).

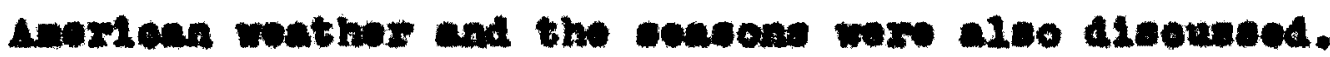
Jepanese catlag pleoes In Poxtland, the now Japanose garden bader conotruotion in Wahlagton Park, a party given

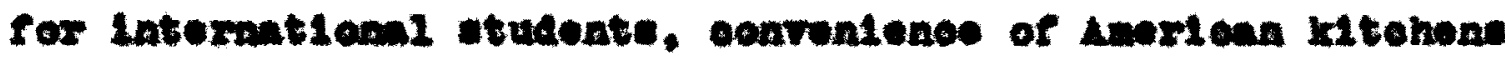
and Anorioan friondingen ooplote the list of toples not sentlonod earlier that we coneldered by the Japanese. Through the we of the nDus-se sxeat doal of oultural datin wo epontanoowny contributed by group monbers.

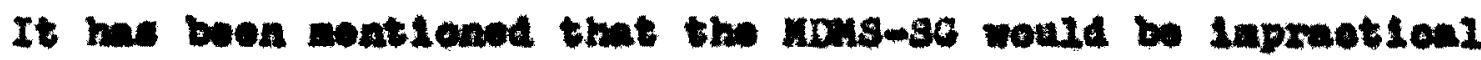
as a cole wothod of ellalting othnographe Information.

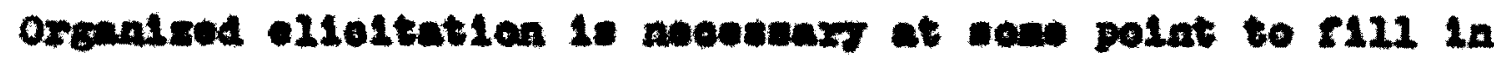
the leoune and for the determlation of whother or not reorganimatien, ro-eategorisation and remoleanisieation are 
noagers.

sinn:

The toples alecueved by both the Amb an the Jepm-

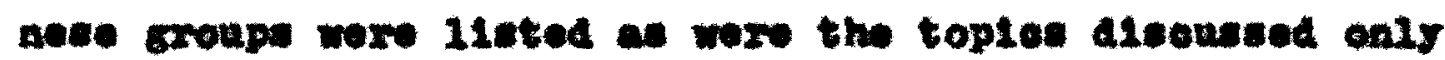

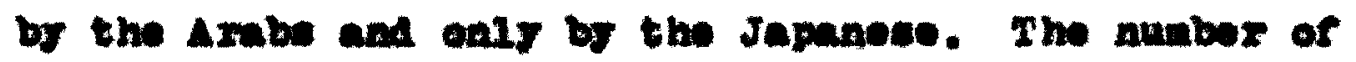

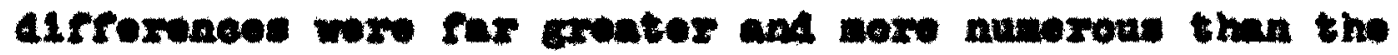

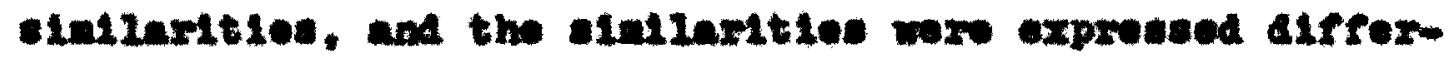

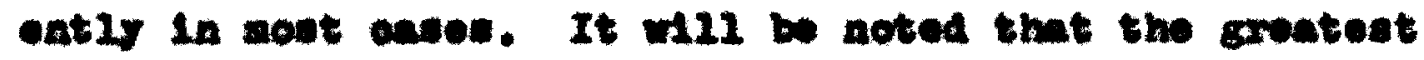

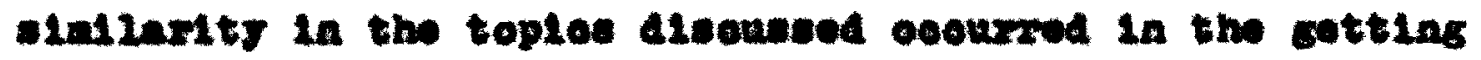

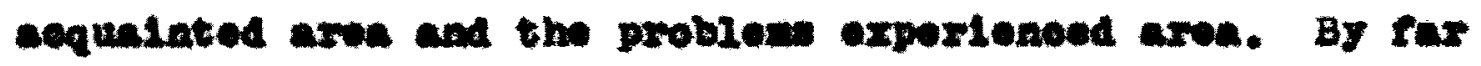

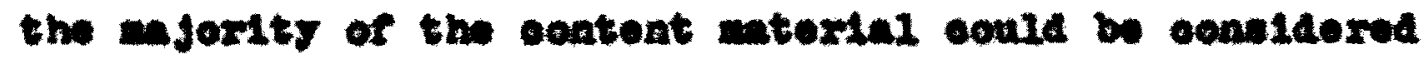

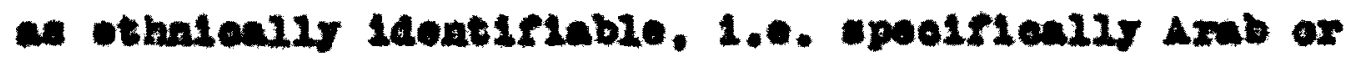

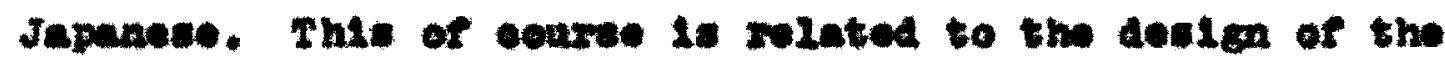

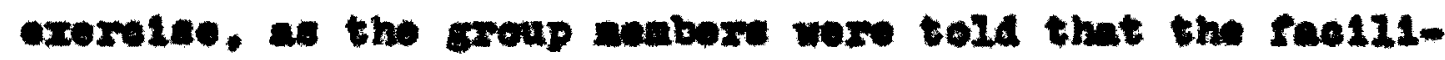

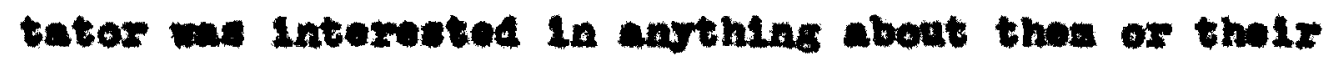
conatry of oxteln thit thet whhod to talk about.

\section{SORILRI}

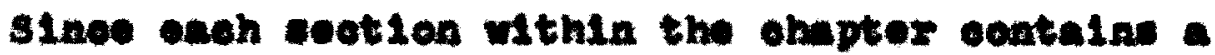

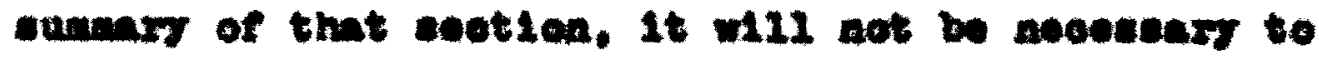

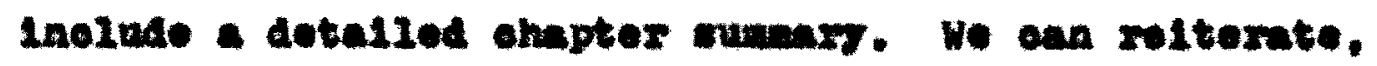

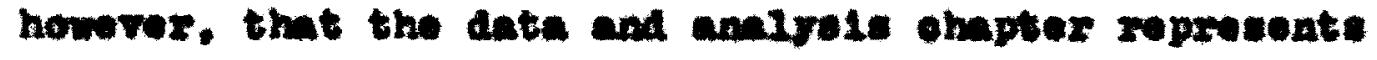
obermatlon of an ontity or eloned eorpus. 1.6. a wot of

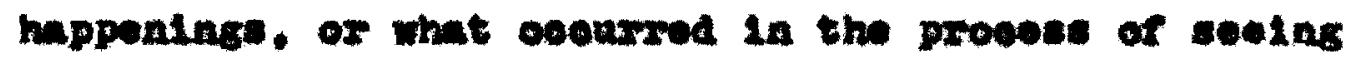

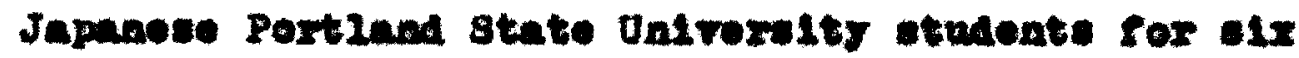


meetings in an wOMSG setting.

Nans faoeta of bharior were exhlblted by the groupe and obsexved by the inrestigator. These racets of behavior were organized Into large oategorles suoh as "esotions expressed," "oleases of Intermotion exhibited," eto. The antegorles theaselres wore eapirieally derived, that 13. they resulted fros a sorting of conorte obserrations. seah eategory wa subjected to rurther analysis. One oould refer to each of the eategorles and resultant andysis as an espeot of analyale, eaon different fros the other and representing a difrexent Viem.

The firet expect enooupesed the reactions to oonstint reatures of the MDHs-SG altuation. The reaotions were examined and it was found that alx of the constant roatures were roated to differentially by the Arabs and Japanese, and two reatures were reated to similerly (or. page 49).

Seoondzy. It we apparent that different types of organization were arielag within the two groups so thie was deseribed, analjzed and compared (or. page 56).

The reation to the constant features and the type of organization the Arabe and Japanese arri rod at within their aroups wero grouped together and oallod situationoriented responese. to differentiate thon from aspeots of analyels wore elosely assoolated with the rerbal naterial. Thirdy, the manner of speaking, in the Arab groups as opposed to the Japanese groups above and beyond what 
oould be olanelfied under alfrement acoente, seomed entirely different so theix apoeoh wa studied so that spoclelealis what it was that wa difrerent could be 1solated and labelled. They differed in fire eajor maya (or. page 60).

Fourthly, the Armbe seosed to laternot with each othor in a wy that alfeered from the way the Japanose Internoted with ench other. Tho rimet major task was to obeerve tholr bohavior and llat the types of Interaction that oocurrod. The list was agaln induetirely arrived at. 1.0. It was besed on observation of the groupe laoluded wthin the olosed corput.

The Japanose ahowed ton intexaetion patterns which the Arabe lavelved in the corpwe never shomed. The Arabe exhiblted sereateen whioh the Japanase netrer showed. There were thirty-four patterne of intereotion whioh wex shown by both group bat of those thirty-four, only ten a1d not differontiate the two sxoupe. Ten othexe were ahown to bo exhlbited noro frequontiy in one group than in the othox, and fourteen were shown orer twice as rrequently by one sxoup as oppesed to the other (ef. pagen 61-69).

Pifthy. the esotions shown by partiolpante in sach group were 1solatod, Inbelled and sonpared, Twenty-one onotion were comen to both groupa. $\mathbf{8 1 x}$ were exhlbited by the Japanese but not by the Armbe and twolve were oxniblted by the Arabe but not by the Japanose (of. pages $82-84)$. 
The Plnal and elzth anpoot of anlrale contere around the subjeots disoussed. It involves a content analysis. The toplos of converantion were elaselfiod and compared and 1 we found that while thore we a oomen oore of topion disoused. what was sotually disoussed in torms of dotalle we highly difforentiating and othnioally eignifioant. although inoomplete (or. pages 84-98). From the above liet of anpeote or anmlyale, the trpes of inforwation whioh the nDws-3G an anthodelosy is oapable of providing oan be dotermined. 
CHAPTER IV

THE BRLATIOHSHIP BETUEEN THE DATA OBSERVED AND PEEVIOUSLY PUBLISHED AUTEROPOLOCICAL MATBRTAL

In the following pages the date revealed in the prooeding ohapters w11 be disoused and when posslble rolated to proviously publishod anthropologionily orlented anteriale. The purpose for 1te inciusion 1s tworold. P1xat, it mill aselat those readerw who have rory IIntted beskgroum in the othnography of Japan and Sauds Arabla to see the relationship botwoen the respones of the partloular groupe of Axabe and Japanese Involved in this partioulax MDMS-\$G exeralse to reaponses counon enough in the ethalo milion frow whioh the group partielpants wore derlyed to have been noted and reoorded in the liternturs. Seoondly. the oootion following ohould alarify eapedilly for the conventional anthropologiet (a) that the MDAS-3G not only rofleot the oultural conditloning of the partiolpants but (b) that it auplesents the venal lints of "what to look for" in a oulture. and aleo (a) that it glve the anthropologlet a woalth of Infoxwation about a oulture in an oconomioally erflelent mas and would be eapeolally viluable if vialting the country under study wore unteasible.

The date and analjale was broken down lato $1 x$ 
A1rizions, enoh a riev of a difrerent aspect of the total

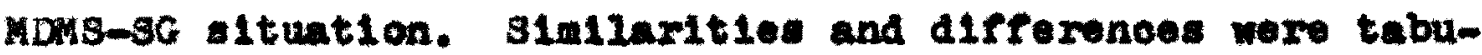
lated and difrexenoes were enphesized. These oberrvat1one w11 be related to Informtion obtainod through normal anthropologloal fleld eethode and sourees other than MDnSSG reeearoh.

\section{SIPUATION ORTEMED RESPOASES}

The riret aubatrision in Chapter III enocapased the Armb and Japanse Bxoupe ronotlons to common eloments in the roaeroh deelgh. 1.0. the neoting armangenents, the tepe recorter. the elningl alreation and alnima atruetur. Ing. the repones to texinetion. the attitude displared toward the role Given to the facliltetor, attendinoe and the reopore to the phrelonl oond1tione. 1.e. the roon. Eaoh alfference observed and deseribed in the firat subdirision has aleo been obecrved and desortbed by anthrom pologlats in nor trailtional eottings. Hetelns Arxangenente

One oees that in terme of weoting armangunats. the Arabe responses to the invitation refleot a type of baharier oonelderod vineble to Ambo in Send Ambia. They tried to brealn with Mr. C. of Portiand state Uniroxity's Intermational Progians. Ther wanted hia to know that thoy aght do him e favor, 1.e. attend the neetinge. with the expectation that he in turn might sonoday help thes out. 
Bargalning is part of Arab 11fe (Barth 1961). They preferred not to say for eure whether they would cone or not. This oould be related to reslstance to belng bound by tlaed obligntion (Fulzer 1961). Thls is not oustomaxy in Saudd Arabla, and if somothing moro intervsting or laportant to thom suah as e rriendahip oonclioted. they would want to be rroe to not oome. An eduontional type mosting with a gradute student is aloo unfanll1ar and would not ooour in the1r country (personal comulunleation).

The Japanese faoed with the same situntion responded In a Jepanose fashlon. The ract that the invitations were apparontly Ignored oolnoldes with Benedlot's desoription of the phenomens of 1 gnoring happenings when one 18 in oodfliot al to autable way of respanding. The one Japanese student'a readinose to oooperate with and to meet with tho Investigator whom the ldentiried as the wife of a former teachex oould be related to the ract that teaohora (oonsel) In Japan hold apeolal place in Japanese soolety (Singleton 1967.113). The relationahip botween student and teacher 18 often moxo bladins than between otudent and student, 0.6. professors often are oalled upen to arrango marrlegea of got jobs for the1r atudents. There may have been an elenent of reduolng ono' reellnge of "on" or obllation tomard superiore by dolng the former teacher's relative favor (Benodiet 1946,103). Th1a was of couree not cheoked because the nuture of the seneareh desigh (the 
uDMS-3G) prohibited $1 t$.

\section{Ten Baonder}

The differentinl sespoase to the tepe reoorder elso 1. probably rolated to entural oonditionlas. Students in Japan have moh wore familiarity with the machino, eapeolal-

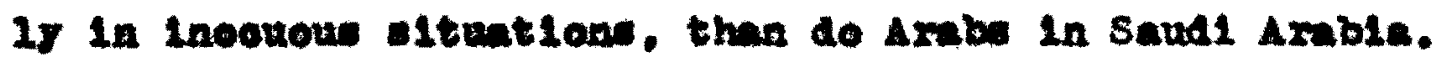
However, both group had had expertonoe with tepe reoorders In the Iangange Iabaratoxy at Portiand state Univerrity. The Arabe' quottions as to ornoxwhp and future use or the tapes were not initiated by onls one partiolpant. but were a group oenoera. It wo orlgimally laterproted by the inventlgutor a poasibly a polltionly based unplolon. but thia oxiginal interprotation wa modified alnoe okin. reotual anowern allared the notivits.

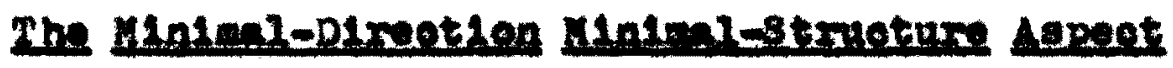

It wa epperent thet the Armber eridenoed noro disoonfort in respense to the Inok of dimotion and struoture than did the Japanone. Ther alked tho group facliltator to ask question and wors orition and lapatient at the laok of formalled leadorahlp on hor part.

Lipato (1959) in his book seydl Arbils, an organized oonpilation of Informatien from the Middie Eant f1I and saud Armbin flie in the HAf atates in his ohapter on Soolal Ralation that in saud Armbla "thare is no question

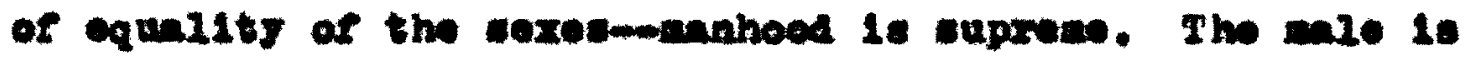


looked upon as the segraestro and respensible acter in the eoelety whioh it is teeltiy asound would dislategrate if aen wore not present to give alreotion and enforoe order." (b. 297.)

The facliteter we fowale and by researeh doelen relatively non-dimetive. It is masonable to aseune that thelx efforts to provide both etruotux and alrootion were rolated to a dosiro to oxhibit qualitioe rolated to thalr ldese of wele superiority. The Axabe seend to want to ale sure whore they atood, who hold what power and what was expoted of thon in this unfaniliar stuntion. In Baud Armble thore are formallsod patterns of pooting and one oan Landiately tell the comparative otatur of the partielpatias partien and the deternine future boherior (Pleree 2971). With no olanaleal wy of soting to tall beok upon, It is poselbie that the Arebe exporlenced genuino disoonfort in this oltuntion. In eddition in saud Armbla an and women who are not rolated do not attond moeting together (Howarth 1964). It id probable that the only non-elaseroen experienoe with aon-fonlly adult fomales that thoy had had wo tho dating rolationohip for a fow in the United states. If thie hrpothoule is oorreot thoir behavior. 1.0. thelr gronter ronotion to ilniall almotion

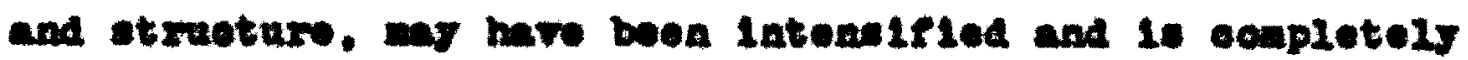
logieal in terme of thalf pat othalo experienes. Clubs are not an Inportant part of sand oulture and aro 
prootleald non-existent in oonnoctien with aohoole (perconal oomminiention).

The Japanose on the othor hand have wany elube. woot-

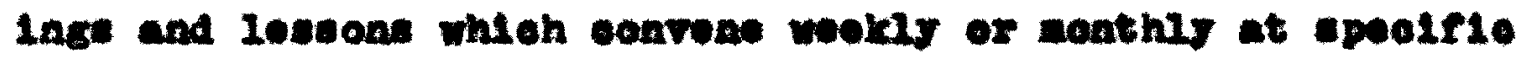
tinos (Voge1 1963). Conlag to a mooting we not contrury to thelr habltual patterne of bararlor. The faot that it was rulatively unotruotured and not lod ald not risibly

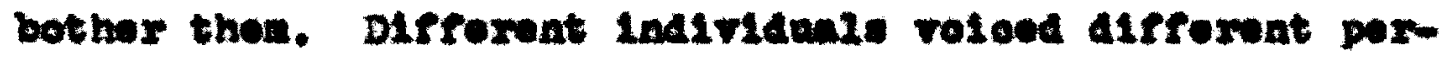
sonel banofite frou attending the moting and the croup faollitater' reason for holalns mooting we apparontly

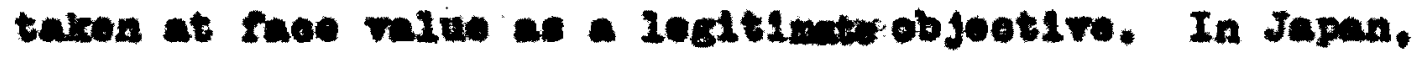
on publio donverences and in partes, roxolgnore aro arten appreachod by Japanese person who sare he wate to praotioe Bnglish or wates to Iearn bout Anorion or wute to talx to an Anerioan, so this roquont of the inveat1gator would not hare soowed unusual to a Japanose. Ihis ay for the have lent struoture of a sort to the amal2 group neoting while the coareree would hold for the Arabe.

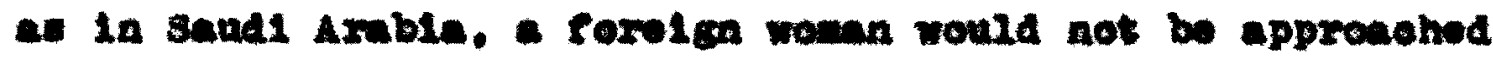
bs saud1, male or fomale. for any convemation whioh was not plannod to lead to come aption. Most saudl women are In puxdn. 1.e. nono of tholy okin or halr 10 exposed (thoy are oovexwd) when eutelide the conrines of thols onn howe or the home of a friend. To couveree with a strangex inplies an latianey beyond the ainple exelwange of worde. 
Besponat to Teraination

The Japanee determination to continue the experlenee and the faot that the Araba ald not motion it (perhape they nover thought of $2 t$ ) weon to again olearly rorleot the pat ethnle expexlenees of each group. The Japanese, to whom non-fanlly formalised groupa wax a fanliliar part of 11f\%. Whod to continus and conoolved of the phonowen of continued exintence. The Arwb did not sugent continuIng and for thon the oonooption of group of poople sinply nootlas at a flxed timo regularly wa forvign.

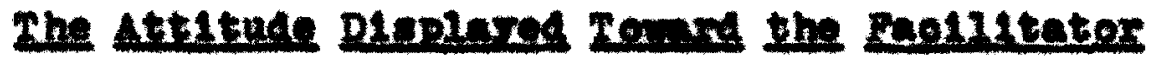

The well-inown Japanose values of polltenese, thoughtfulnowe. and salution of harmony, and habitual respect beharier (Maloney 1965 and suglnoto 1928) for older people or for abrone when they ondow whth otatus oolnelded with the habltual beharior of the Japanee durting the group seasions toward the sroup rabliltator.

By coutsust. the armbe waxe often intense and enotlonaly Involved in trylng to convinoe the faellitator or the superiority of thelr arsunoate. Tholr bohavior teward the rasiltator variod. The faot that hor andenod role ontrted for the Armb and remined fired for the Japanoes 14 probabls miated to the raot that in Japan rolon axo

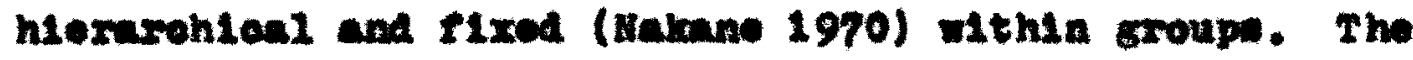
anthropologlet Ch1e Nabune (1970,31) also says, "wlthout 
contelousness of ranking. 116e could not be oarried on onoothly in Japan, for rank is tha sootal noxw on whioh Japanene $11 \mathrm{fe}$ is beed."

By contrast, In Sand Arabla, apoording to Lipacy (1959.299). "any coolal eltuntion in Armble roquires conelderstien of atuperior abborlinate mintioas. - [whion are] not hiexarohienl but remin on a trometep level."

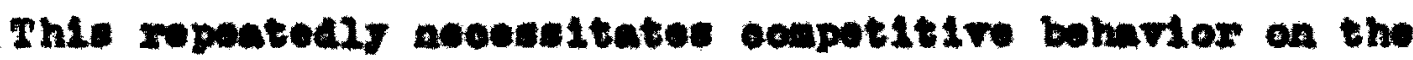
part of Arabe. It is elenifieant that the rwearoh design.

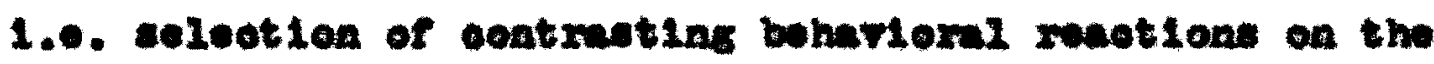
purt of the Arabe and the Japanese to comen faotos in the HDMs-36 altuntion should so rivily polnt out thin laportant type of information.

\section{Attondanes}

The rinal anpect of the total sttuation to whioh the Arab and Japanone group reaponded dfferentiy we attendenoe. Attondaneo pattexno Afferod in tho two groupe. Both Japanese wales and fomales oane to the mootings bet only Arab malos attended. As wa montlonod oarlier, unroluted Axbb wen and woma do not eathor and oenverwe in publie In sand Ambla. Thin is eald to be done at least partif to provent an fron bolng plaoed under undue strese by reninine otinulation end pastif bocaupe it in oseontial to fanlis honor for a romale' reputation for parity to be untarnished (Pleroe 1971). It 10 poselble that this 
Injunotion could contribute to the raet that no Arab womon ohose to attend tho mentings.

The Torekg atudent rooter of Poxtiand state Univerw sity for the apring of 1969 I1eted aoven Armb romalos and

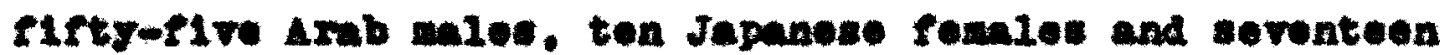
Japanose males, so etatletleally, one would expeot a higher propostion of Jupanese fomalee anrway.

In Japan, on the othor hand, oomeduentional olube exist In wone collogos and oven some dating ocours (Vogel 1963). Vogel also ant "while danoe partlea aro not uncomon in eollege nowadnre. dating etili is not midespread, and at high wehool age it is vistunlly unknown" (p. 117). Sinoe anee and fomelen aro not ziglely uoparuted in Japan 1t would be arpmelng if in the Unltod States thoy ohose to be.

Wore Axabe than Japanose attonded sessiond, approxlmately twenty-thxee to ton. This rerleots the aotwal forelgn student enrollest numbers.

Nelthor Exoup wae punotud, but the Arab stbdents inrolved wero leas punetual than the Jepanese.

It If Interweting to note hore also that in one of saud Axbiale prinelple elties. Brahd, the author an won warling two watehas, one with the diel sot as a westernor wight got hie watoh and one oot for rellelous purposes. The Intter is reset ally to oolnolde with the appoarmaoe of

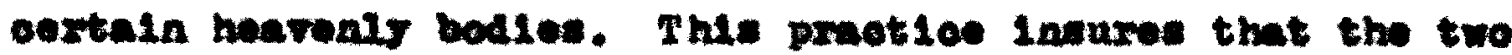


watehos w11l norer regleter allke. S1nee at praver tiee othor actiritios unrelated to religlon oeses (oren shope mut be olosed), and praver tla ocoure at a elsht1y alfrexent tine dally, on would expeot that a sandl Arab's lden reganding tine wowle affer from those of poople trow other oultures with elfrorent exporienoes.

Besponae to sudto-plewel Technteran

. Both group Iganxod the provenoe of the andio-visual

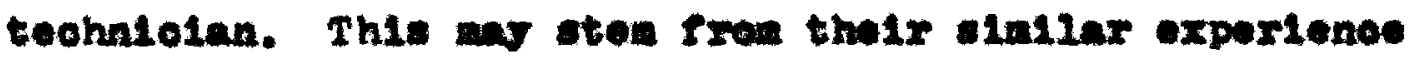
as poxtind state UnI veralty etudente. Thoy had all been exposed to the teohnlolans in olamser at Rortland state and ens have been follenting wat thor conpldored normal

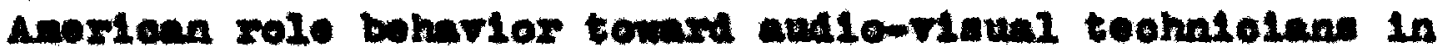
a oleveroon altuation (or. pagea $45-46$ ).

Besponse to Phralon condtions of the Boos

Both groape rospoaded the wen to the phraloal sovonodntion, 1.0. the roen. Both groups were fanlilar with the ceneral aroe and etate of alexepalr so it is possible that they woxo used to 1t. It Is equally posalble that vonothing in the ethile background of each group oontributed to the general 10 w level of roupenas to the dirt and olutter. Both the Japanese and Arabe are very oloan and unoluttered in tholr ow howas. The Japanese, who are

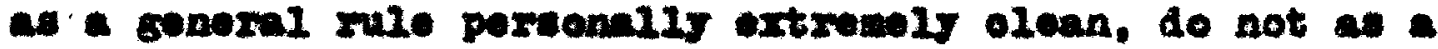
mule have atrons sones of personal olv10 pride in 
conneotion with oontributing personally to kepling publie bullalnge and publie thoroughraxe aloan. Th10 is aloo true of Ambe in Ambie. In cadition to this, Axab an of atetue roport that thos do not engage in what they oonsider apnlal woxk in erant of othore. It is pousible that dolng anything to olean a publio room which thos woxo onj uling was outelde of their ldeas of noxand appropriate beharlor and ald not oocur to any of the partiolpante in elther 8roup.

\section{Sunnaxy}

It $w 111$ be noted that in each Instanee when the two

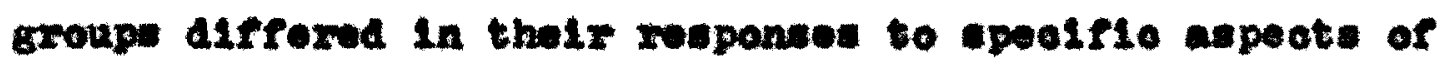
the total sttuation, 1.e. Woting arxangenents, tape reoordor. MDMs sepoot of the moeting, ete.. the Alfrering mosponses oelnolded wth ethale desoriptione found by other anthropologlate waing othar anthropologion mothoda.

The above interprotation and oulturaly rolated explanationd formulated by anthropologlets who obserred behavior in actual riela altuations seen to be equally epplicable to the olnilar boharlor obeerved in the group conoexned.

Thie 18 Igenifloant beave It aucgente that the MDMS-so is a valuable Inotrument in that it provides a - Ituation in whioh an anthropologiat can obeerve wember of a veleoted othale group, exhibiting behaviox 
ohmeraterietle of the larger ethale group under study. The boharlor obeerred in the group. serrelates with obserratlons ade by other anthropologlots uaing moxe txadtional nothodolod.

II. COMTRASTING PATrEaks OF ORGANIZATION FOAMED BX THE TWO GHOUPS

The weoend aublitioton in chapter III dosertibed the obeorvation of the inventignter in rogard to the developwent of contzestive pattern of organization. The Japanese and the Arrbe behaved very Alfforeatily and these

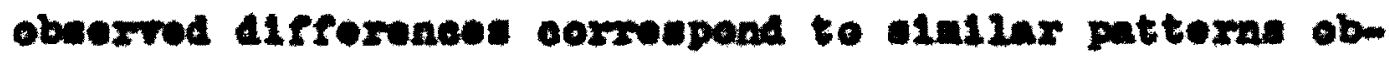
corred and leseribod by anthropologlete In Japan and sanal Axabia.

The Pettern of orrandration in the Inganere Gronp

Ch1e Hakne (1970.II) in har recentif published book

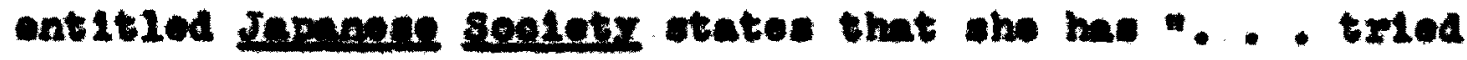
to contruet a alatingalohing reaturs to be found in Japanese 11fo." The book expounde upen what Makane oal10 the rextien prinoiple. she enye $(1970, \mathrm{x})$.

In $a$ flow the nont oharueterist 1 e roaturs of Japanose soolel organizatien ariece from the olngle bond in soolal weintionohipe, an individunl or a sxoup hal alware on ingle distinotive rolationehlp to the othor. The working of thie kind of relationohlp eset. the uniqus struoture of Japanese soolety es a whole. which coatrunts to that of onte or olase seoleties. 
She dicousese the Internal atrupture of the ldeal Japanose group. (It w1II be noted that rabene' une of the term otrature is related to what is borola moferred to as organisation and ahould not bo confuned wth spoctalisod parohologieal wee of the term strueture ued in this theate.)

Wakne eare (1970.51) Whaterer the1x olze, Japanese

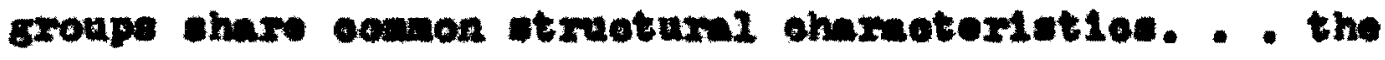
1deal type of offeotive group 1s that whloh is organleed

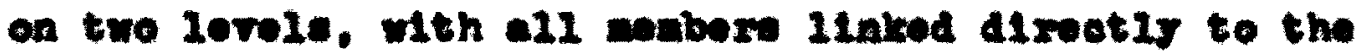
1oador." A Alegranatio roproventation almizar to hor: followe. The larcer olrelo represonte the leader or that peraen with the highost ruak, and the onaller olroles roprosent the othor group nombers.

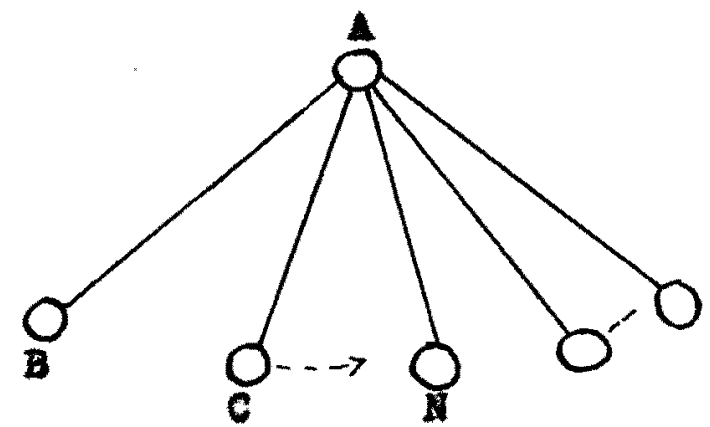

110ux 2. Japanose 1deal trpe of effoet17o group organization diegramatiealis zopresented (after Naloneo)

Note the bale elaliarity botween the groupe deneribed by Nalane and the Japanose Hous-go undor Investigation. Navano uees a baeloes triangle (or. Figurs 4 ) to 
111uetrate the ldee that twe sroup nombers. B and $C$, weh have a relatioantp to $A$ bat no ldentifiable relationship exlate botweon B and $c$. Tho addition of a now nonber Inrolves de altemtion in the mak of an exteting monbox as be 1 plneed on the lowert mak

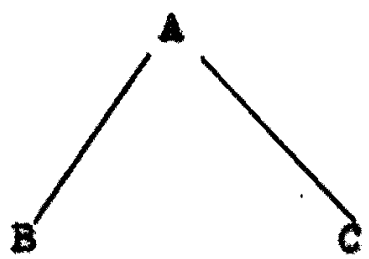

Plax 4. DLegmantio representetion of a rextical rointionthp.

Ladowhip is reotrieted to one indifidual. Figure 5 112ustrates the oonoopt that for example a monber $D$ owes

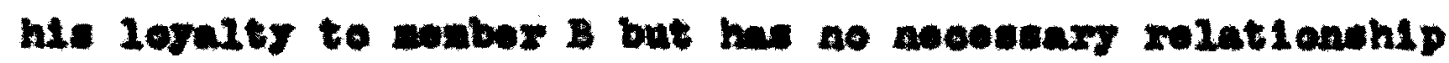
to any other momber in the group.

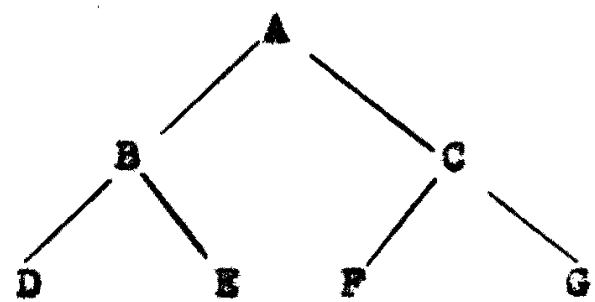

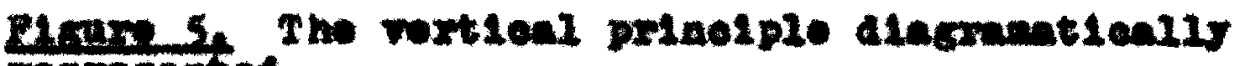
Ioprosented.

If this eoneept Is applied to the data deseribed in Chapter III. 1t rte alnodt poxfeot17. B. hat the poattion

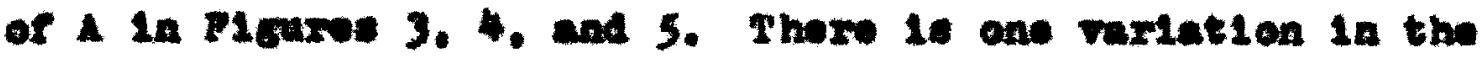
Cosign. H. Coelgnated S. an en elternate. A2l tho othor group 
mabess ath the exeeption of 8.18 two fritende who attended apormdioally on be roprosented by the sanil olroles in rigure 3, and the vertieal zolationship by the Iine between $A$ and $B$ or $A$ and $C$ in flguxes 3.4. or 5.

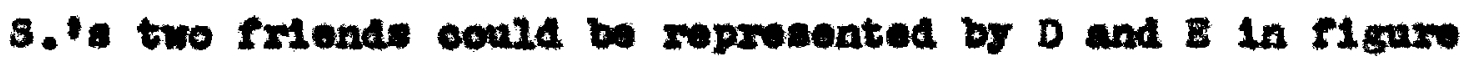
5 if $B$ wore to reprosent 8.

Nakene desomber and labels the beharlor of the frlend of $S$. who sooned to not $21 t$ into the forming srotell. She would probably be an exanple of the ripplat okan1" (1970,44), or lone welf, and mubjeot to ortraesan from the group who have a oemen loralty to $A$. It happonod

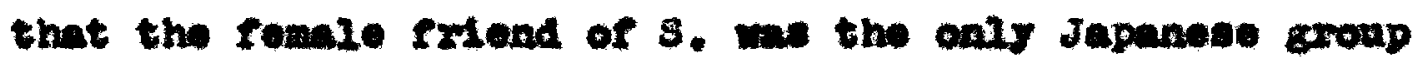
nember to be tempornmly outrwolsed by the croup. This oom ouxred when she, arriving Iate wationed that Japanese had alfriouty rinding other Jeganese rriende in the United States. The sroup had just been epeating of the ritendy

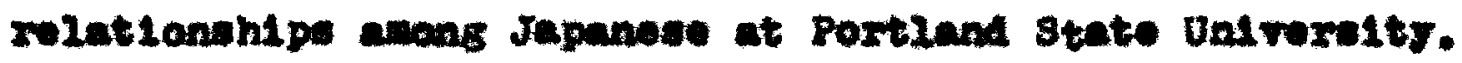
she exhibited wht the Investigntor labelied as a foar $x 0$ epones and in the course of the follomis aleouselon sedifled hor statemente, al Ald H. so thet egroemont wa reachod, One alght note hexe that the Japanose Inngunge has no torn for the woxd leadorwhip. It wees inetead kinehtp toms reforring to parant-ahila rolationohips. Nalano

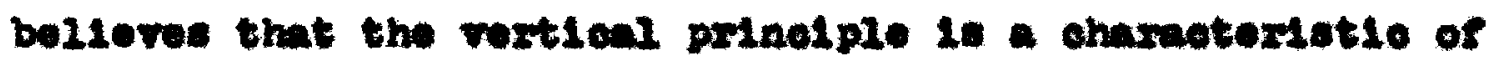
Japanose coolety. It Is axtronely Intereating that when a group of Japanose unthored in tho Untted states in a 
eltuation whero group atruoture and direotion were not inpoed from the outelde, 1.0. the moms-so, thoy proeeded to denonotrate Nakne's rertiele princlple without ever haring hourd of 1t. It coese that the mDnsmse is one rerifteation of the prinolple and the investigntor an conoelve of no other derinitive wa to toat enoh an 1 dea. or partioviar interost is the feot that the researoh we conpleted in 1969 before the Invertigntor had been oxposed to Malkne's riow. This dononotmates one of tho edrantages of the o20sed coxpus teohnique. That 19, one is forced to obeerve a given corpus in 1te entiroty and one orten in owrprised at the soauts.

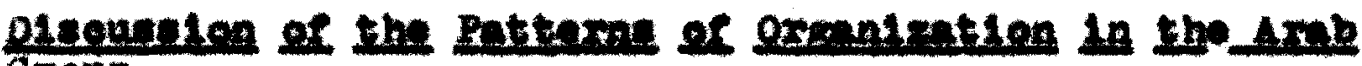 crope}

The Ambe rofused to meocente anjono as a leader and expreaned tho dontro for froeden to think, aet and belleve a Indiriduale. In Vabue's terme the croup had an horlcontal menor than a roxtleal oreanization.

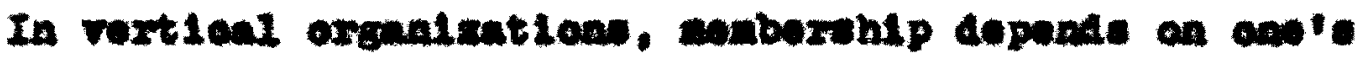
beoulins acqualnted wth and soopted by one of the nenbers. Looses to the group is Internetional and way alffer from

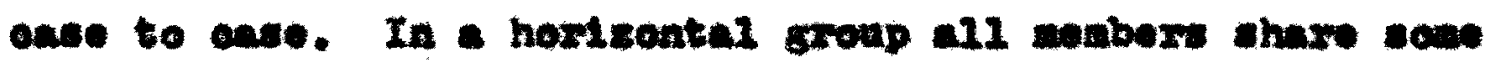
attribute ouoh a belng oolleagues at portian state ox in

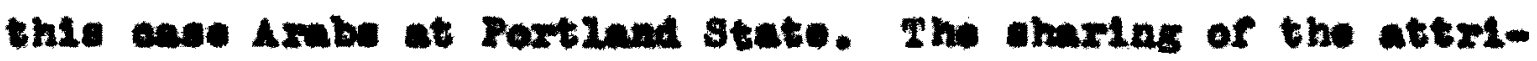
bate is Inportant to gulnias aooess to tho group not a pre-formed perwonal relationship. 
In vextieal groups the addition of new nembers is easy, but because of the Inriexible struoture, the now mosber ean't oharge his relative atatus within the group. on the other hand, In a horisental groug. theoretloally an Indifidual can take the place of an othor. The now nowber stands on the sase footling as other nombera. If a

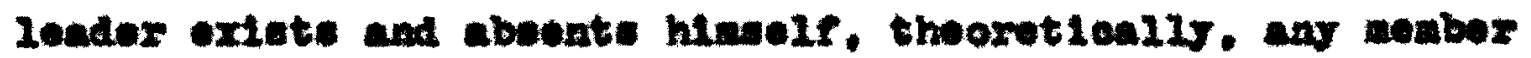
oan take orer.

An shalyals of Hear Eastorn Comitted wosberwhip boharlox has been ande (Grr 1951). The nothod Involved laterviowing repreceutatives frow the Near Bast, uslag fixed but open-ended quootionalixe. Gry found that the

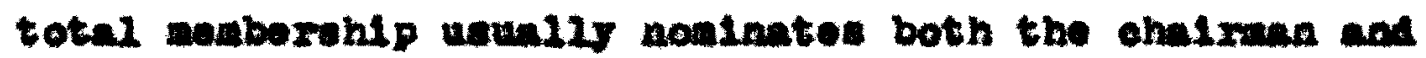

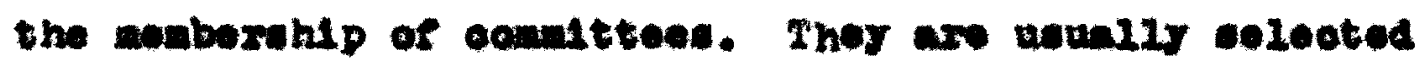
for expextnoes and my elaultanoously zopresont connt1tuont groupe. Chatmen ung exprose tholr om oplatene and repsosontative are froe to hange thelx riow anding a dieouselon.

The eposific oxigin of tho intexwioween in the atudy 18 unknown, but the horisoutal rather than vextloel pattern 18 erident as it wa in tho prosent anall group otudy.

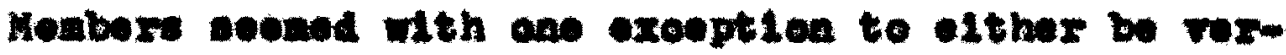
bally competitive or zelatively llent, and older nonbers

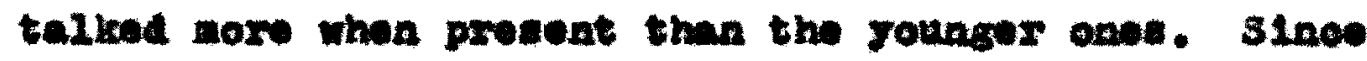
status is mote oloedy aseodated with randy 11 noage and oooupation in 8audl Armble (LIpale 1959.63), and the croup 
we ade up entirely of studente whose Ilnsages were unknown to the Inreatlgator. this type of rolationshs could not be oneoked.

In fact the Invoutlgator wad unable to find desoriptlon or Interpretations of observations of organizational patterne in the 21terature.

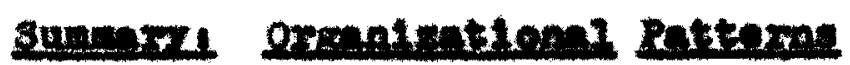

It w11 be noted that the Jepanose pattern of ox-

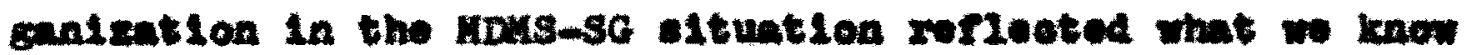
about the Japanose patterns of oreanization in Jepan, 1.e. the rertion prinelple. The Amb patterne in the nDMs-se

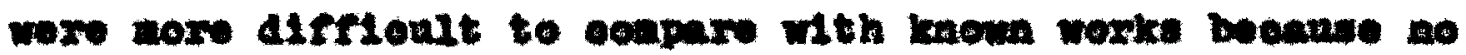
deceription of tho oxganisation of groupe sonld be found. Howerer. Haland" horisoutel puinolple wa lilustrated and the sawe prinolple was how to have beon lllustmated by the orr otudy of comalt tee hombers boharior in the Near Enat.

Hothods of forming workting sroupe in the KDMS-SG are epparant2y otruetured by pet experience mithla the ethale eroup of whioh tho Individuale the coupriee the group axe - part. and the Noks-30 glves the anthropologleal Inventigator a seans of gutting at this raopt of knowledge. If one were to une the HDMs-SG with an watudied othnie group. the form of organization the group moberw ohose to was would oue the laveatigator in on thelr mothods of 
organizles thouelves athin tholr own oultures. The prooses of group formation is almont impossible to ellolt frou 1nformants direotiy. It met be obeerved, and the nDMs 30 1. a teohnique whioh nakes this tJpe of observetion posalble.

\section{PARALIMOUISTIC BgHAVIOR}

Ho material on paralingulatiog as such wes sound by the Inveatigator in asther the linguletse or ethnogenhio otudien avaliable. Paralinguietios is now field and is es yot a category of phonomen melatively unoxplored by ethnologiats. Anthropologieal 12ngulete aro atudying it in connotion with Englieh at state University of How York at Burfale and it could be analyzed for any soolal group whose

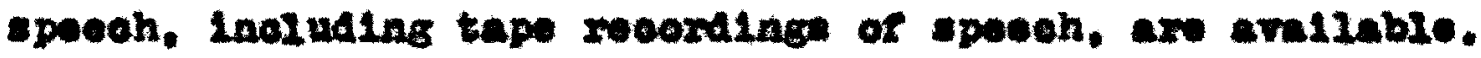
Tho date colleoted (pagea 57-61) sussest that rate of opoeoh. average veluan. Fange of variation in Intonation and averm

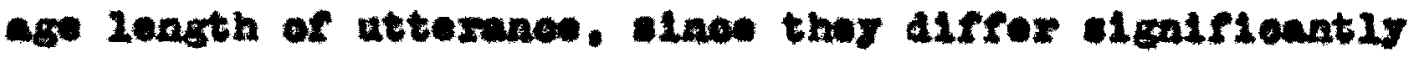
between the two group:, are learnad patternod bohavior and related to hablts cequired as mobers of thelr xospotive ethns. groups.

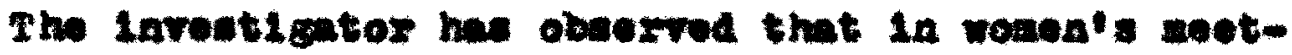
1ng and axod mooting in Japan, whloh the attonded, tho Japmnese aembore ald not apouk Japanose $20 u d y$ as if orwting. Tho wonon tendod to malntale alatively even high tone and the mage of variation in intonation was not 
great enough to ocamand attention. Thil observation oolnoldes with the obserration ade in the MDHS-SG situation. The Investigator, however, aleo noted that in Japanese motings partiolpants tonded to take turns girlng short opeeches. This is oontrary to observations wade of the UDAS 36 altuation. Tharefore, it is poestble that length of uttermon is zulated to type of group gathoring or aco othor leoleble verlable which anly furthar rosearsh sould deteraino.

3intlarly. the paralingulatio phenomens obwervable in the Arab WDMB-SG oorresponded moxe olosely to parallngalotio phenomon aneolated with Axabe spenking Armble than wth Amorloans opakling Englion in groups.

It Io Interseting to note that in the book Armbina

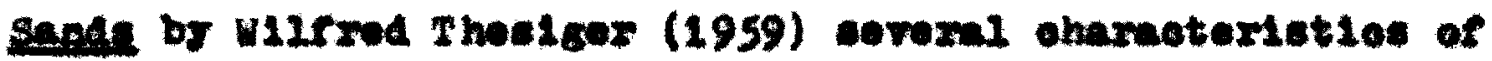

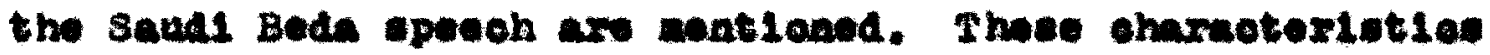
aro not labelled paxalingulatio but aro novextholoes rolated. Thealger saye. "Boda alware ahout at each othor, eren if thoy are only fen foet apart. Erexyone oould theroforo hear what was bolng sald by everyone else in the eanp, and anyone who was intereated in a oonreration round another firo oould join in from where ho was alting." (p. 48). He also montions tholr dislike of silenoe, saylag. "Thoy are unplageling talkers. A wan w12 tell the sase story half a dozen times in a couple of sonths to the sase people, and they w11 sit and 11aton with apperent interest. They sind 
It an almont unendurable hardship to keep ellent" (p. 72 ). Wh120 only one Arab in the group ldentiried hiaself as a Bede and he and his fathor were olty Beda, a rolationshlp may neverthelese exiat between speech behavlor of the respoted Beda Amb of saudi Arabla and the Portland state Unlversity Seud Arab student's apeeoh beharlor.

Thea findinge atrongly aggest that tho parringulat 10 phonowens are wore elosely arsoolated with the Individwel and $\mathrm{hls}$ oulturel beokground than it is with the 2angunge 1earnod. Desplte the faet that both group wero opeaking gaglish, the paralingulat io phenomena observed apparantly oorrenponded to that normal for tholx onn langrage and oulturmi horitage and not noreal for Bnglioh. Purthor Intencive etudy of seleoted sanples is nosessery to dotexmino aceurntely both the soope and neapIng of the paraliaguletie phonemone procent in the opoeoh of nomber of each of the ethnle sxoupe involved.

IV. VERBAL IMTERACTION PATTERAS

What conotitutes habltual interaetion patterne for

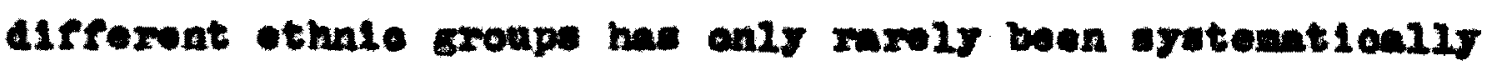
-tudied by anthropologiats. No studies of interaction patterna in Japan or Saud Arabla wero found. Therefore no comparisone oan be sade. The present study dezonatrates the contrantive nature of Internotion patterne of Japanese and Arabe at Portland state University. That the contrast 
1s "oultarally oonditioned" mthor than due to Indiridual. personal differenees is epparent becuse differont Indifiduals oave to different group metinge yot the interaotion patterns for the Arabe remalned dietinotive from thoes of the Japanese.

It 10 posalble that those interaotion patterns distlagulahing the Japanese Poxtland state Univeralty atudenta and the Arab Portland state Unireraity students inrolved in the present study could be uned at a bese for further more Intense othnologlenl researoh in Saudi Armble or Jepan. Surviy suoh knowledge would have protionl as well as acadenie algniflounoe in our world toder with its often rerballzed enphasis on oommaleation and understanding.

V. EXON IONS IMPERERD FRCW VERAL BBHAVIOA UTH THE CONTEXT OF THE TOTAL BEHAVIOEAL SITUATION

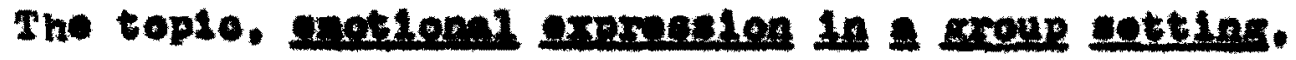
1. not a tople touohod upon by noat othographors. Wo

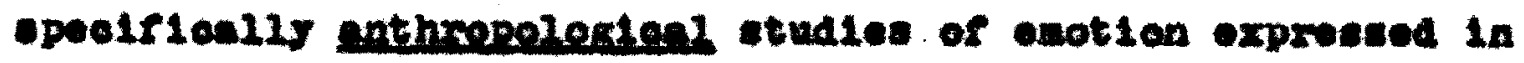
enall eroup sttuatloa for elthor Jepanose or Axmb peoples hare boen wade ox metten up ar far as the author of this prosont manuseript oan spoertain.

Thie statement should not be construed to sean that the tople enetion 10 totally lgnoxed. In the 11 terature on Arab oountries an woll ar Japan, It 10 pontioned. Fox exanple. five of the alx onotion chareoterialng the Japanese 
MDN5-3G and nover oxproened by the $\Delta$ mb HDHs-30 waxo ex-

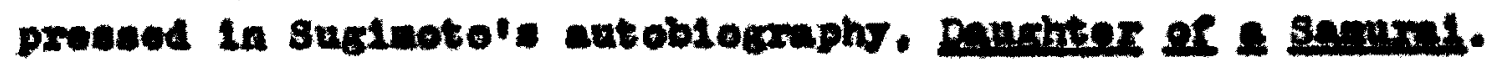
Suglnoto rofore to ber on foeling and revotion to

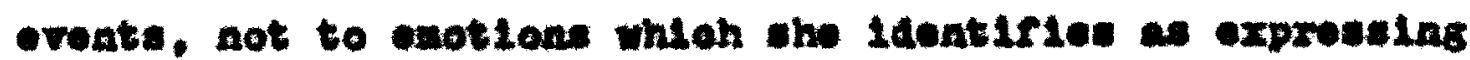
in a group setting. The elediarity is, however, perhape agniflount nerextheloes. Information on onotional roeetion is aleo a by-prodiet of Japanoes T.A.T. Ituales. Those are given to individuale in a non-group ootting, but

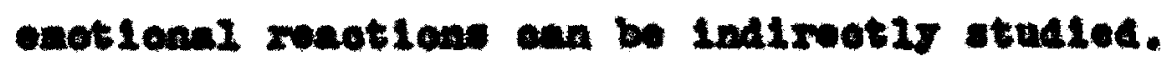

In saud Axabla, onpolally from sooounts of p11-

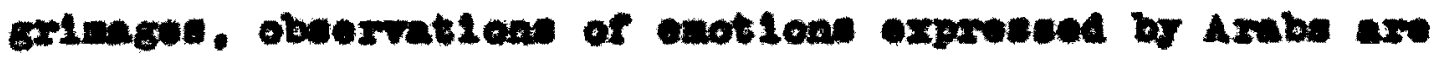

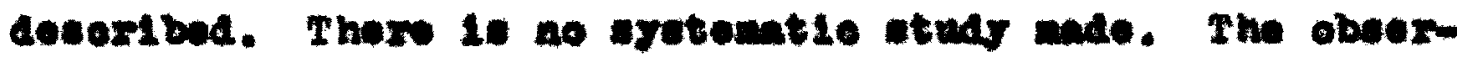
vatioan exe montioned as part of the total experienoes of the metterv.

The stud of the tople amation while almont obeont in otudies of sand Armble is not Mrein torritory in the

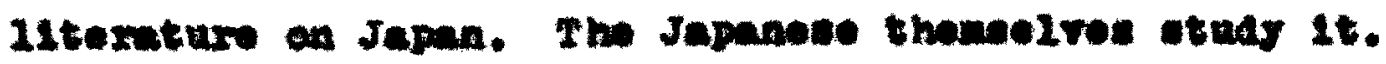
The author is awne of anveral exeolloat articlea by Japanose parohiatriste whioh have been tranolated into Eaglish (Muxamatou 1951. and Dol 1961 and 1967) and soveral written ortginaly in Bnglioh by non-Japanoeo. Inoludine Amoricans. with the purpose of botter underatanding Japanene onotional dorelopunt and dranalon (Holonor 1954). The ronder Literm coted in the tople is alse reremed to Bonodiot (1946) and Gorer (1943). Anemoan anthropologlete, and Iannoto (1964). - Japanose anthropologiat for solated for Aletingulenod fron 
oongarable) wertes. The Inventionter feele that a furthor atudy. Mthin the bedy of the thoule. while porhape of both

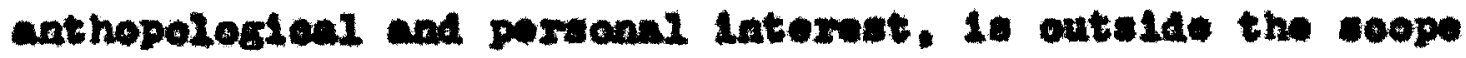
of the purpose of this thesle.

The Inportanes of the study is not on one or ond ons not find anothor souree which agrees with or xerutes

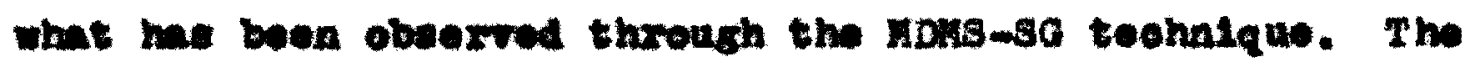
Leportanes 110 in the faot that ans he the opportunlty to obaerve and learn from and about a croup of poople who are provumably althe in wowe copondable way ohosen by the Inveatigntor. In this one othateally. Ho obeorves tho in - Altwation which ares the monburs of the croup the oppoxtunity to expreas thowedves in a excative way. 1.0. what-

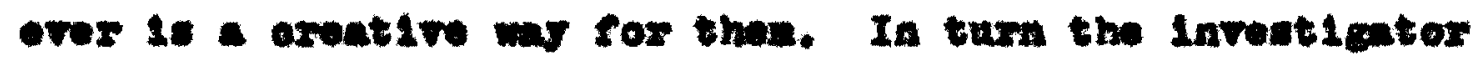
he not ony ops lafoxent but sovoril simultageously. As Is the oase with all eenpotent anthropoloctats, ho loes now than analye the answers to the question he has acked. In

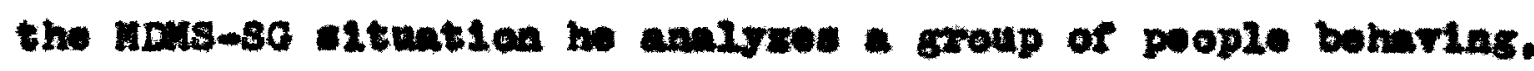
1.0. talkine, rosponding, Intermoting, onoting, he aces. for exampe. how ther onote and flade out to what thos enote as we ceemibad in a pxoviotas section (of. 69-84). It buppos the the vous-30 altuation 10 partioulariy oulted to aratenatic etwey or enot1on.

The larger andes of anotion leolated in this

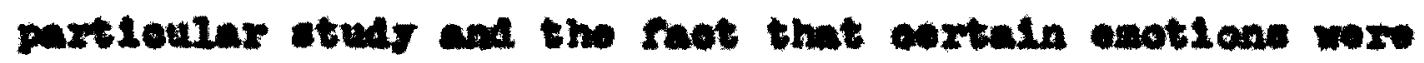

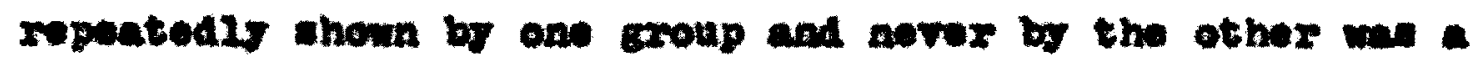


coures of eoroadipity to the inventigntor. Iho anthrom pologlut beause he Inoke toole or teahnigued raxoly attompte to atudy emotion. The nows-3G provides this tool ror anjone wo inclined.

\section{vI. Conn ENT}

Cortaln teples wore disewesed by both the Armb and the Japanose onall groupe uador conslderatien and osrtaln othex toplos wexe dleouneed by only Arabe or only Japanowe. In the ohapter on cate amilele it wo noted that oren thowe toples ocmon to both sroups (with a fow excoptians)

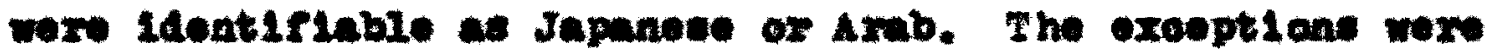
prinolpaily centered around thelf alnline roles an form

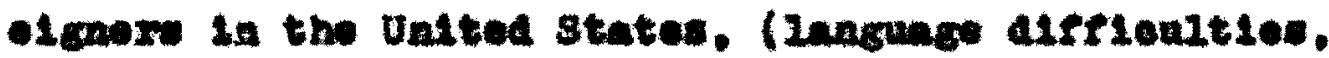

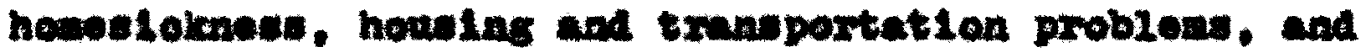
ad Juotenate to cultural alfremenos). roxelen atudente at Poxtland State Uadrerelty (1.e. atudy diffiohltien) or.

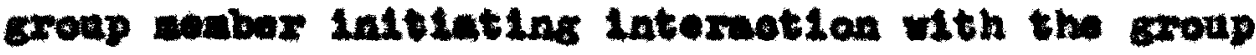
fach14tator.

It w11 be noted that the othnogmphio Infoxuntion obtalned had twe ahnrateriotion (a) it was inocuplete and ungrtenetized. an would be expeeted, alnoe the ob-

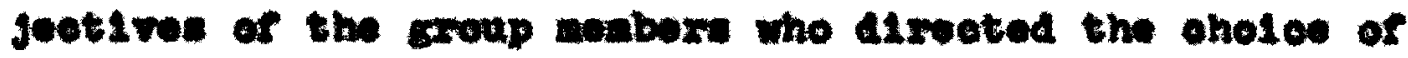
eaterials to be alseused wax not the same as those of an Anoriean-trmined anthropologlet tring to etudy and wite en othnogmphy, and (b) it wa exteneste in broadth of 
subjeat atter wa rerleoted what other anthore have obserrod to be of Inportinee to the natives of Japen on the one hand and seval armble on the othor.

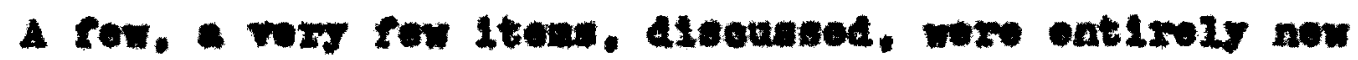
to the Inventigater who had apent conuldermble tiwe in both Japan and the Hidelo East. Thio faot is atgalfieant for two

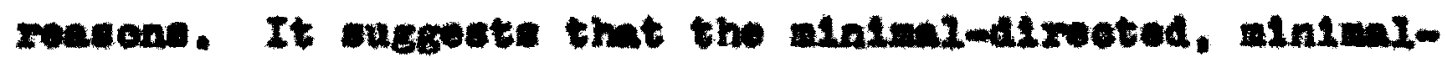
etructure appot of the andI group teohniqu is not userul to the anthropologiet laterouted alniy in othnographle Information gethering. espoelaliy if he elrosdy has faniliaxty with the oulturw. It also aggoate that the anthropologlet who is unfauline wth a given apeoleto othele sroup sould aquire - broad opetran of anthropologleally relovant enta, eapealaily of tho trpe that was

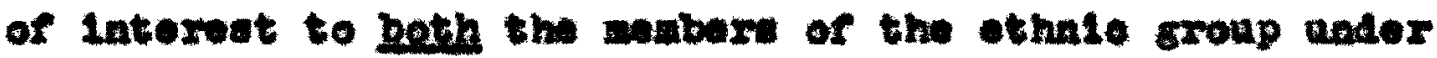
perroal and the anthropologiet, and that this infermation would oorrelate highly with the trpe of information he could aoguixe in the rield situation.

In the next fow pagos wowe of the spouflo ilfrexenees in content alsoused by tho Axwbe or the Japanose w112 be related to elnilar flainge in the enthropologlan 11terntur. For exanple, only the Ambu disousaed marriage pattorne in the tribes. the advantegee of polyenmy. ountomary preodieres to follow to find a whe. arotome of nailing and the sorerment 's aroten of condins atudonts abroad fox further eduention. Ihe Axabe wex Intent on 
ae112ng the I1utener on Arabla's sodernity, beauty epote and cocosplishments. They ontered Into soolologlonl and politieal disousalons and wothode of produolng ohange inoludins, "how to Inrluenoe the older soneration." In the

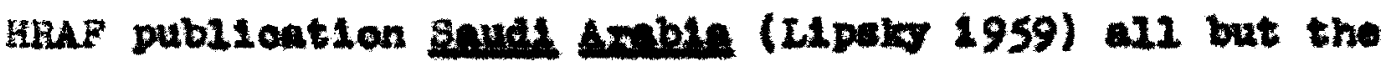
latt 1tex, that of how to inhivenos the older generation are montioned. From a protion atandpolnt, the lavt montlonod toplo would be mox appropxlately diecused "enar tran home."

Turnkng now to those item discunsed onty by the

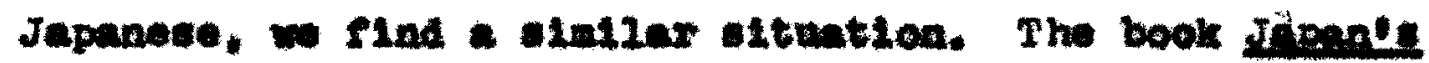
Wex Mldale glese (Vogel 1963) mations all of the rollowIng toplos disounsed by ony the Japanane. Japanose ohild rearing proosdures, the Japanose "wav." (p. 83) and

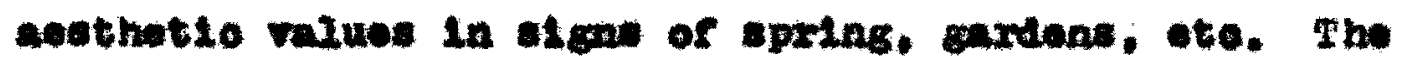

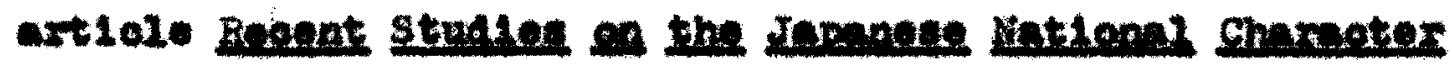
(Yrannoto 1964) wentions as ild the Japanese in the present sample. the Iaportanee of harmony and thoughtfulases, and of colng what is expeoted. Ho also santions a displayed Indifferenos to pollties whoh eolnoldes with the lave of polltioal disousaton among the Japanses in oontrant wth

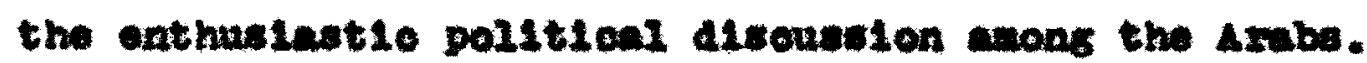

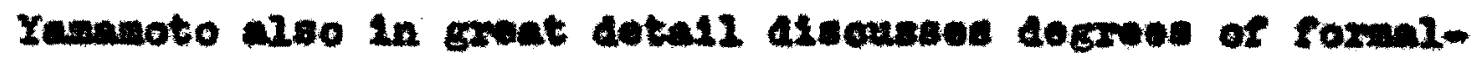

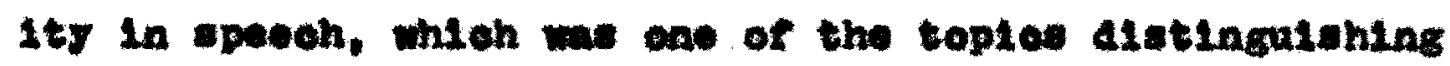
the two sroups. 
wth Hower armangenents and tes and oonverwations about pootiry and drame oan be attested to as a cosinon part of converation by alnoet any obsexver restaling in urban Jepen loas enough to ongage in aesual oenverantion wth -dueated Jepanose. The ano thing oan be seld about

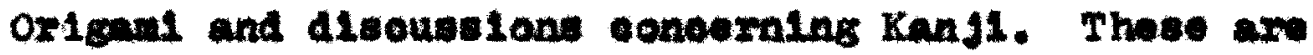
frequently aentloned by Japanese at leat whan senveralns with Amerteans.

It oun be weon that the content of alseoarme in the HDMS-SG zorleote cultural pro-oonditioning. 
CHAFIER V

SUMHARX AND BVALUATION

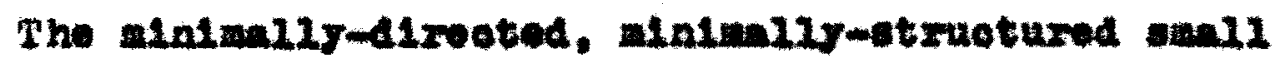
group, a modifiontion of a payohologionl toohntque, was used to in anthropologtan inights. The nothod was

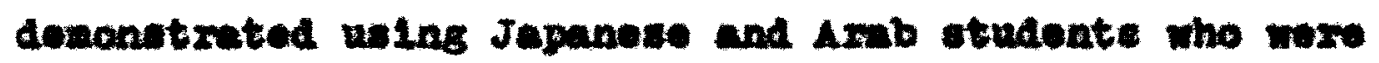

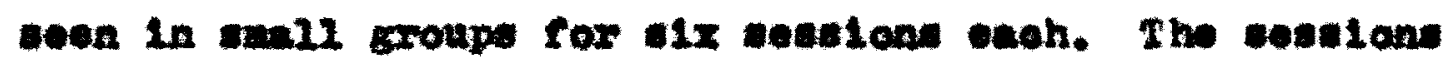
were oonduoted in a faghion permitting maximus froedon within each group for aelf organization and gelf direotion.

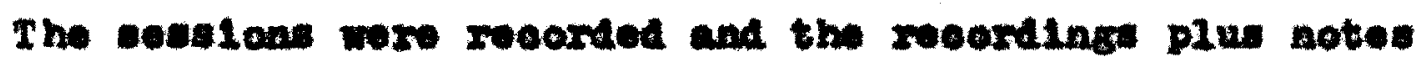
taken Imbodiately after each cosalon by the investigator werw trentod an a alowed soxpul of data. The material was thon compared and alfrorenoes wexe noted, The material seomed to rall within alx oatogorles of difforenee. These oategories woro induotimely dorived. Thoy aro minted in that eaoh 10 a part of a elaselfiention of differengas. and they axe weoh an aspet or a wy of looking at dati. rbose difforent ware of looktng at ante axe adnttedy caslex to eohleve by Individualao mportenood in amell croup prooses than by the norlos in the teohnlque. One is tratned to becens awne of Aletinotions onoh as alfromonos in patterne of Interastion and throagh the prosese of exporionoe beome able to mplely and seleotively attend to 
thea, difrerentiate botween thom and ldentify them. Thene entegories have not been lieted previouly but students of group theors in partlouler w11 reoogeles that the invest1gator has morely 2 abolled whet the alort group faoliltator matohe for in the sroup atting.

The ontegorles Include atudy of the croup noubers reactions to the various faosts of the experimantal o1tum ation, the enmit from the phyaleal setting to the degrwe of atruoturing impesed, and an analyais of tho otjle or oholes of laternal oreanization. The raot that oholoe was permitted of coures wa a funotion of the sinimal struoturIng reature of the croup doelgen ohoen by the foolittetor. A thind category Inoluded the Alfrexwnese in the manner or oty1. of epaking whioh oceurrod. A rourth eategory of Alffexenoe enocupanged interwotion patterns and the firth. -ations expresed. Tho slxth eontered about a content andrali. thet is, about the alfromees in subjeot natter whloh wore actually talkod about. Problows brought up in the course of the group neeting wore not treated by the Livestigater any alfroxentiy in this atudy than other types or oontent materinl. In each or these alx ategories.

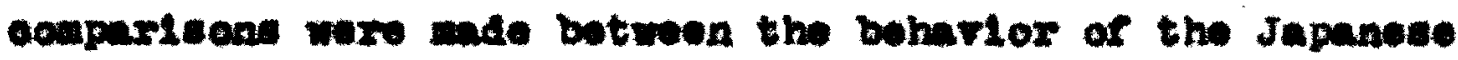
atudents and the Axb studeate. In fire of the elx cases thore were moxe Alffexenes than almilarttion (the exoep-

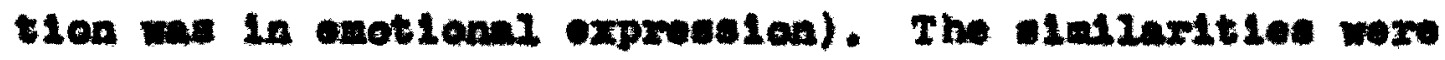
licted and the responses exhiblted by only Axabe and by 
only Japanese wero aleo noted.

Arter the data collooted and analyzod, those Alffereneos which had ando thomedres apparent wore onooked Wth oxloting anthropologloal Itorature on Japanese and Amb oulture to detexing how the date eolleoted through the use of the Mols- 30 we eimilar to that oolleoted by mox conventional woane and how 1 was distinotive.

It wa found that the resetion of the group monbers to facete of the exporlent whioh wers hold constant with both group waxe rexy elmilar to thowe zuported by anthropologlats studying Japan and Saud Armbla.

The uDys-8G was tound to be an exeellent tool for diseovering how group organtzen 1tself. The two group orgmalaed thomelve ontixely alferently and the pattern of exganizetion in the Japanese abull groupe rotlooted what hat beon stulitod about Japanow pattorms of orenniention alwowt perfeotly. Lees is lenom ebout petternm of organiention in Saud Arrbia, but the date rrou the nows-SG show a alnilarity to that whioh is known.

The ubus-se proved to be a exlafuatory nothod for colloet ing parallngulotio data. No ons has publiahod the parmilingedatien of any non-Indo-Europoan 2anguagen thut rar nor atudied the paralingusistle boharior of apankex of

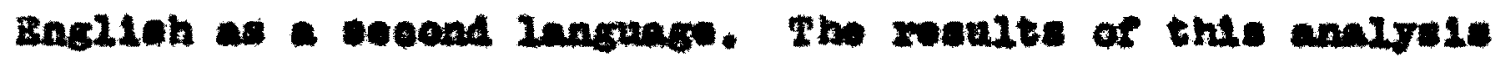
make It ovident that oextaln payohologleal and porohom 11ngulotio sosuptions mut bo challonged. Lingulata and 
perohologist: mut in the futuro realize that extra phoneale elgnals may have zoletively standardized ananings for all within a given othnie group or language group and the ande olgnel any have asfroxut opeotfio meanings in another given othalo group or language group. Group faoli1titor are taught to seleot out purmIInguletio ineongrutties. For example, a poron who, aurIng an axgument, houte. "I do lore jou," $2 \mathrm{~s}$ aending noro than on mosage to the Ilutener.

The roeulte of the paralngulatio portion of the MDNS SG sugseat the poadiblitty that now paralingulatio roatuxes are more olosely assoelated wth ethalo-group prooonditionling than with an attompt on the part of the

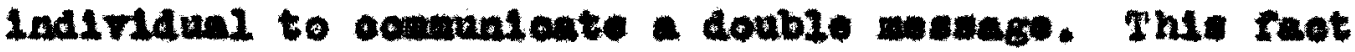
could be rexy important to the forelgn otudent adrisor. oounalor or to anyone woriking with lodividuni sponklog English as a soond Langunge.

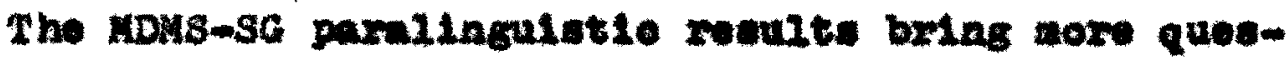
tion than andwore lato the anthropologten eubmeleld and sugseat a noed for rurthor researoh, The MDMS-8G was found to be an exoellent mans for the syetenatio atudy of Intermotion patterne and also for the atudy of the expreanion or oxotion in a group setting. Both of those

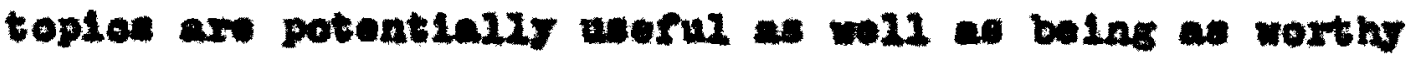
of study as any othex phase of ethnoloss. The uecfulnose 18 alf-ovident. Tho athropeloglet who know the 
standara Internotion patterns and whet esotional expresulon 18 acooptable can oextalny relate and communicate with his

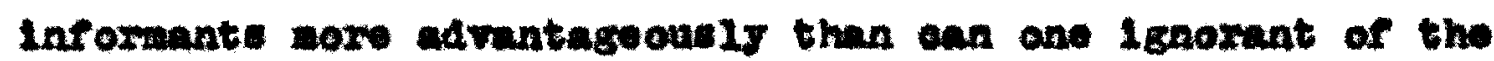
renetion patterne of those he seaks to underttend.

The final entegory of findings, the oontent, ylelded reaults very sinliar to what the othnologiat might find in the field. The alnimal-direotion and minlmal-atruoturing aspet of the anall group altuation rendered the results ungretenatio and Inoomplote, The recults, however, wero found to oorrolate highly with rouklte roported by other athropologlate using alvorse wothode.

In rogend to valldity the rosults augest that alnoe most of the content. 1.e. Intornation obtalned through the wae of the MDus-sG. antohes that reconded by tha wee of othor anthropologienl sothods, one can assues that the information obtalnod through the we of the HDMs-8G is an nocurate we that obtalned by more traditional moan.

The anjor advantege of the NDWS-BG al an Information anthering tochalque is the 11relihood that the uterlal

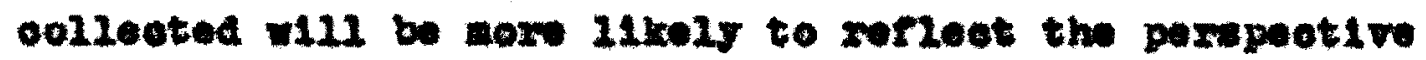
or the croup nembers than of the athropologiet.

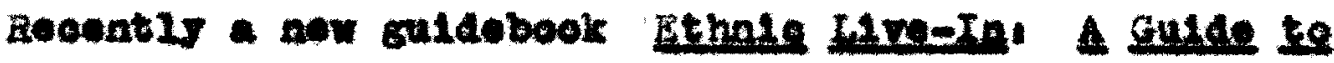

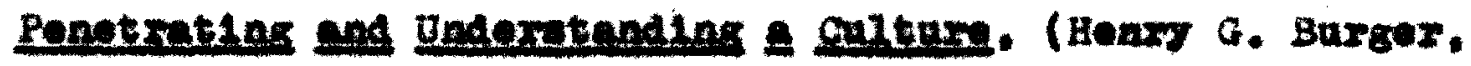
1969) we reviewed by flrmbayaht (1971 in1) who sars.

I would 11ke to Intergeot a more serious (to me) thing conoexules tho subjest netter of thi. 
manuel. 1.0. the ethnlo groups. I an apeaicing more now ss a nember of a minority group than as a profesulonal. A qulok inapeotion of the entegories of date that the author suesente colleoting rovel. that these would rosult in faoliltating couparisons with 11ke categorios derived originnily frow the doulmant soolety, thl approach would not noceasar117 foous on those aspoots tron the perwpetive of the ethnlo peoples that would rleld an underetanding of a oultural winority-othe stated goal in the sub1t1e of tho canual. I met polnt out. however, that this is a eoneral ocaplalnt (on the part of sout of us) about ooclal solenes theory and mothodology and not apeolflenily of Burger. (of. Johnenth B. Cole. "Culture, Nogro, Bleok and N1 gever." The Blank Seholax. June 1970).

What 18 sald in the above quote applies as well to other oultural groups as to minorities.

The use of the MDAS-SG ean be 1nterproted as one attenpt to go book to the souros-mthe people that make up the ethalo sroup-and study what thos do and ony and how and maybe why, In an effort to penotrate and underetand a oulture.

All anthropologlots noed not leara unall group toohniques or In partioular the teohniquos of alnian dirootion and alnimal struoturlag any more than all anthrom pologlot: should learn how to do enrbon 14 teats in the leborutory. Only those anthropologiate aeking the type or deta that the uDMS-SG teohnique glelds chould train thesselves for the actirity. 


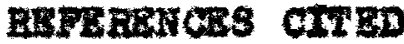

Eaxe. A. P.

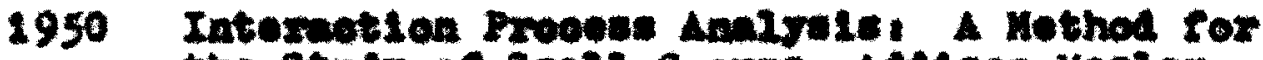

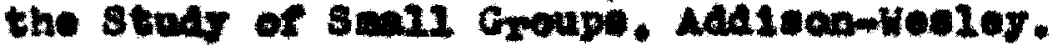

Barth. Fradric

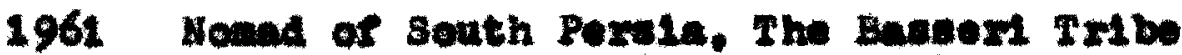

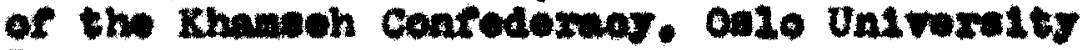
Prones.

Benod 2ot. Guth

1934 Patternm of Culture, Boughton-Hirmin Co.

1946 The Chryouthoman and the sword! Patterne of Jepanose culture, Heaghton-kirsin Co.

Bubar. Nureln

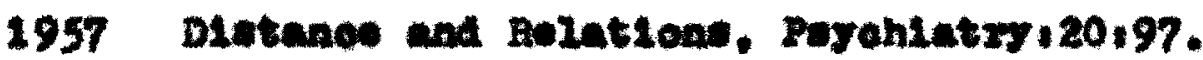
Bargar. Have 6 .

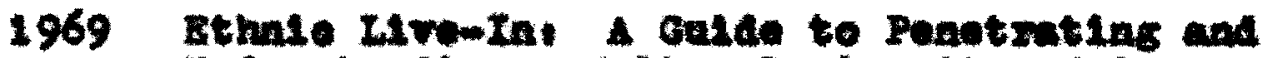

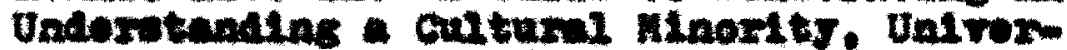
ctoy af nleseurs Proen.

Buxtea. Hehard

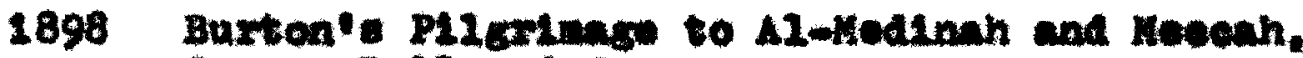
Coover Be21 and Bens.

Cande11. W1212a

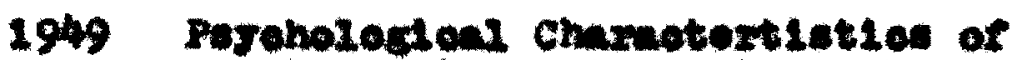

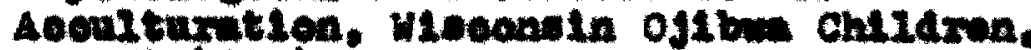
Mist, $409 m+427$.

Cole. Johneth B.

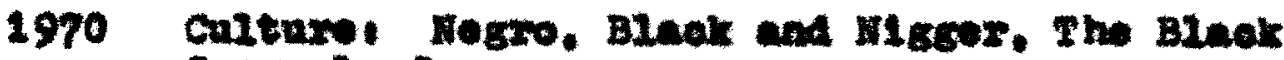
Jouran1. June. 
Coon, carloton s.

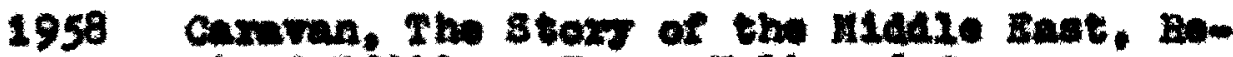
vied Buttion, Denry fiet and co.

Detros, Ceorse

1960 The Rolation of Calzt Tomard Paxpate to

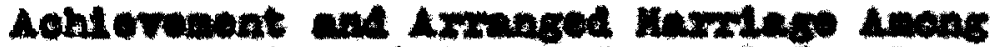
Jaganose. Pajehtetsy: Joureni for the Study for Inter-perwennal Provobees. 2313.

DLelvemen, E, R. R.

1949 The Arwb of the Deeert, A calmper Inte Badamin Life in rumet and sand Armbla.

Dol. Tekeo

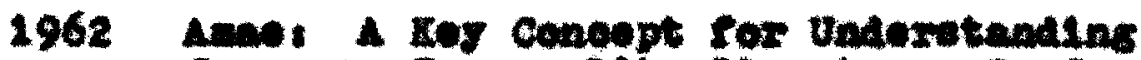
Japanede Poreenality Stmetur, A. J. Snth and R. R. Beardiley (ed.). Japanese Culture. Aldin Pabslehing Cengans.

1967 01x-Minjo: An Intermotation in $\mathrm{A} . P$. Dox (ea.). Anpeote of soolal change in Nodexs Japen. Prineoton Untrexelty Prese.

Dona:. J. F. and Brmall, R, B.

1962 Antinal and sootal grpos in the Bxploxation of the ribotian PIatean. In puos in Paport

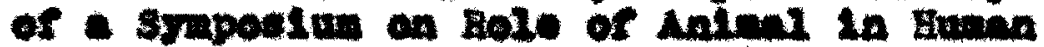

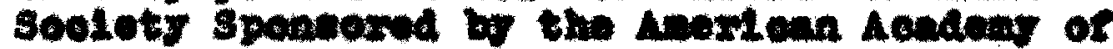
Lrte and selenowe.

Exva11, R. B.

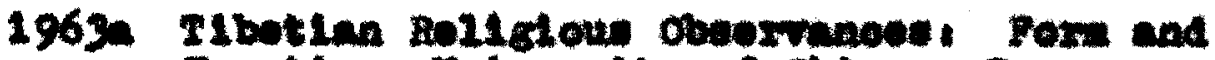
Fuaption, Untroretty of chlouge prose.

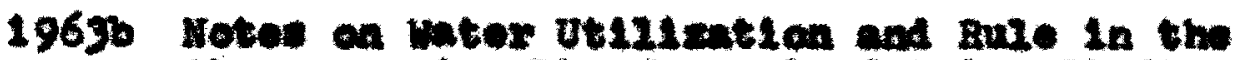
Skeve Domaln, The Joarnal of Melen studies. nas.

Frake, Charles 0.

1964 Hotes on Quortos in Ethography. M.66,312, 1.32-145.

Fuliex, Anas $\mathrm{H}$. 


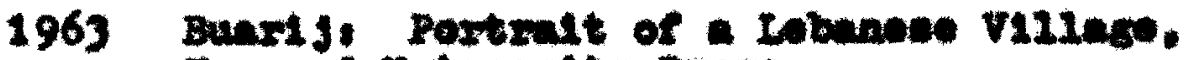
Barvand Uatrexulty Prose.

Coldbors. Pmilip A.

1965 A Rovion of sentenos Coupletsen Mothode in

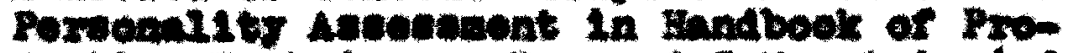
jeotlve Technlques, Bement I Muretein (ed.) Buts Boolve. Tho. 777-823.

Coodonough, waxt $\mathrm{H}$.

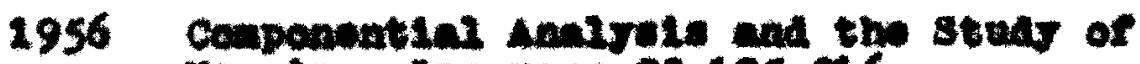
nonaths. Innguge i32 i195-216.

1965 ranke Kindhlp rexinolos, A Probles in

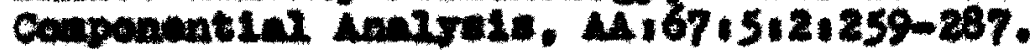

Gorex. Georfrey

1943 Japarses Charnoter struoture. The Institute for Intexnationil studies.

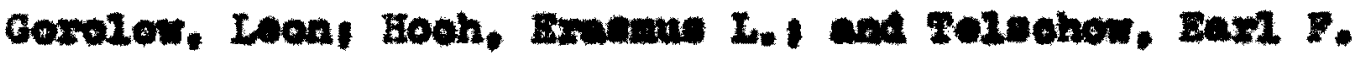

1952 The Nature of Non-dinvet2 we Gxoup Parohothexmpy. Columble Univoxelty Prose.

Gr. John

2951 Anviale of Conattee Honber Beharior in Pour

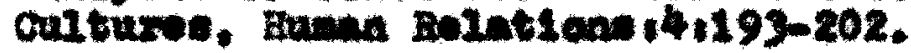

Bali, Jody C. and Jotele, Bxano

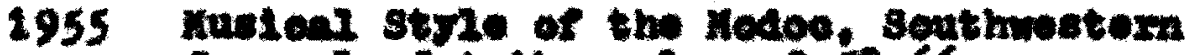

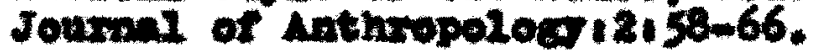

Hallowa 21. A. I.

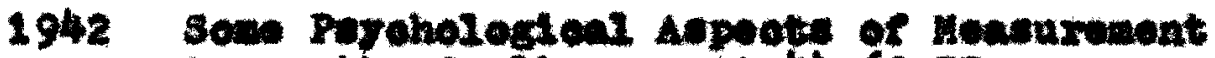
Anoas the savitentr. Mi,44,62-77.

1945 The Hoxwahach reohnlque in the struy of Roxwondity and cutture, Mi47.195-210.

1949 cultux Fotor in the structurilisotion

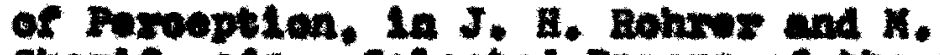
shoxir. cas os selected pupure of the 29th Internatiendi congeen of inortomalete. 2. 105-112. 
Hare. A. Favi

1962 Hinadbook of Small Group Rowenroh, Glenoos Free Prose.

Harr11. 201218

1951 Hethode in stmetural Lingulatien. Ual veralty of Chiongo Proes.

पักรY. JuI

1947 Thowat1o Appereoptien Toehnigue in the stuar of Cultuxw-Ferwenal1ty Bolation, Genotio Peroholect Honogmpha ils.

Heras, Hoger $W$. and Bonale Lippltt

1954 syotonat16 oborrational Teoknlques. Bandbook of seolal Pagholocs. Volume 1. Od. Cartiner Lindser. 370 woh.

H111. W1111an Furott

1962 fill Intemetion Hatrix. publiahed by H111. Hi rabajash, Jaees

197 Book Rerton of Ethate Lro-In! A Gulde for Penotrating wa Underwtending a Cultural Ninortty. Mi:73:2:322-323.

Howaxth, Darld

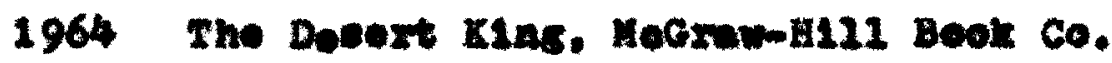
Hon, Franolo L. K.

2961 Payoholostow Anthropolocs, Approaches to Culture and Aathropolors. Dorwor Prose. Ine.

Eunt, Bobort (ed.)

1967 Porwonalties and Culturae, The Hatural H10tery Pxose.

Krane, DeII

2964 Ianguage in culture and soetoty, Harper and How. 
Kaplen, Bert

1962 Studing Perwonallty Crose-Cultural1y, Row Potermon.

Lindzer. Gardner

2961 Projeot2ve Teohnlqued and Crone-Cultural Bosearah, Applotod-Contury-Crofte.

Lipokg. Coorge A. and othore

1959 saudt armbla, HeAp Prove, How Haven. Hocrath, Josoph and Irwin Altewn

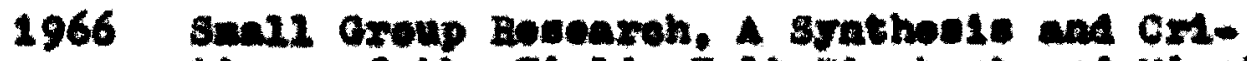
tlque of the Fiold. Helt-ilaohart and Wluston.

Nav, RoLlo

1959 Tho Extotontlal Appreach, Anexican giandbook

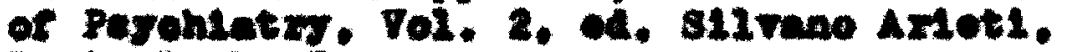
Bento Boola Ine.

Mead, Margarnt

1939 Prom the South seas, Morrow.

1949 hale and Fomale. Noxrow.

Moloney. Janse Clark

1954 Understending the Japanowe Hind, Charles B. Tattie Co.

Murnnaten, Teneod

1951 World renulon, The Payohopatholocs of Internatloan Rolation, Prontioe-Bail.

Maknen, Cnle

1970 Japmene Soelety. Voldenfeld and N10olson. Horbeat. Bdward

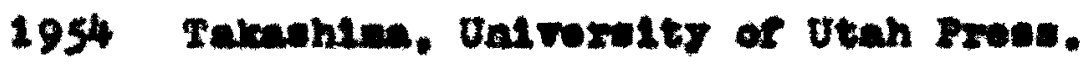
Po1. Maxlo 
1966 Gloseary of Lingulatie Terminolog, Colunbla Unlverestey Proee.

Pleres. Joe B.

1969 A Look at the So-callod-Ing-Forms of Bnel1oh Vorbe. Lingulatied $50,59-70$.

1970 Underwtanding the M1dale Bat, Charles I. Tutste and co.

197 solenes in Inthropolog, In prose, in coulne Fosohrirt for C. F. vongeile.

P2ke, Kenanth L.

1967 Langmage in Bolation to a Uniflod Thoory of the struetur of Human Beharior. Univexulty of Hohsen Prove.

Regers, Carl I.

1948 Couneel2ng and Purohotheraps. Heugitonnirein co.

Roanor. KInball and and Goodwin Ror D'Andrade

1964 Traneculturnl stualen in Cognition, MA,66,3:2. Saplx. Bamard

1921 Language. Baroourt. Brmoe and co. sohntees. Dartd $\mathrm{H}$.

1965 Awortean $\mathrm{KIn}$ Toxwa and Toras for kinswon! A Critique of ceodonough's Compenential

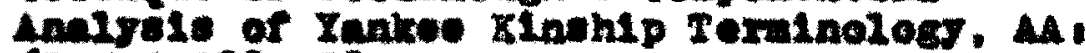
$67.5,2 \cdot 288 \mathrm{~m} 308$.

Sohmb, N111an B.

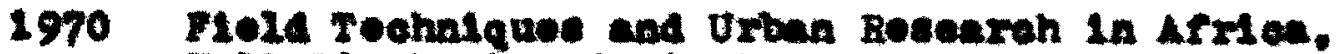
Helt-ilnohart and Hinoton.

3oln. Manus than and Mlan Dandos

1964 Twenty-ghxee Aldalos rrea Centrul Burne. JAFi77.69-75. 
Shord. Haznfor and H. Cantrul

1947 The Puyoholow of Bgo-Invelveacat. John vilor and soan.

shisoh, Al10n, a.,

1969 Poople and cultur of the Middie seot. Bnake Bowes.

singleten, Joha

1967 HLom. A Japanose 8 chool, Cate studies in Bducetion and culture. Ad. Georse and Loules spladiex. Bart-ilnobert and Ulavton.

sartox. H1111an 0.

2947 casobook of Hea-Dimotive counseling. HoughtouMirmia ce.

Spladier, George and Leules

1958 Hale and Fonale Adaptatlone in Culture Chasge. $4,60,247-233$.

Sprearer. Janoe P.

1969 Aaptive strutegled of Drten Meande (anpubHahed ennuerefpl.

3tewand, Denond and the Editore of Life Kagnelno

1964 The Amb voxh, Hre vorid Hbrary. Time Ineoxpoxted.

strodbook. F. L.

1951 Huobnat-Wife Internotion over Bevealed DLrferonget, Amortean soolologteal Beviowi16: $468-473$.

sturterant, v12ulen c.

2964 studien in Ethnomolenes, AA,55:312.99-131. suglaoto, Btea Inagaxt

1928 A Daughtor of the samural, Doubleday, Dorna and Co.. Ine. 
8root, Loulee $\mathrm{E}$.

1970 People and cultures of the Midale Bast. The Natural Blotors Prose.

Thelalger, W1Lwed

1959 Areblan sande. B. P. Dutten and Co.. Ino. Friex, Stophen 4.

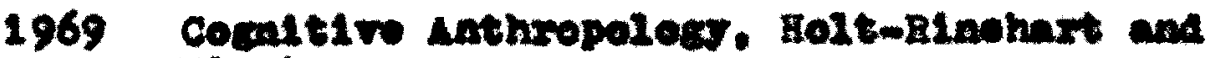
ulnaton.

Vogel. Eare F.

1963 Japan's How Midele chese. Tho salary wan and

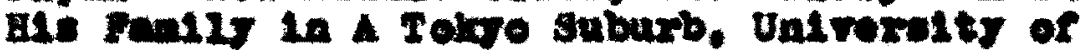
Culifornie Prove.

Wallaoe, Anthent P.

2963 Culture and Porwonulty, 2nd Bdst1en, Bander House.

Hallie. Y. Alion and flarys V. Roberte

1963 Statlotien, Glonoes Frov Prove.

Niener, Claxk

1923 Han and Gulturs. Thomat $y$. Croms12.

No1, Alerander

1949 The Perehoanalrate of Groupu, Anertean Journal of Parohothoxepr $13,4,26-50$ and $4,1,525-558$.

whort. Banjanin toe

1956 Langnage, Thought and Boal1t5. John B. carroli (ed.). Mrr Proes.

Yamanoto. Tatenro

1964 Bacent studies on the Jayanes National Chavester. Crose Cultural Underatanding. Epletomolog in Anthropolocs. Northrop. P.

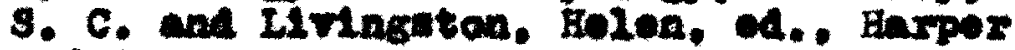
and Row. 